\title{
ROZDZIAE II
}

\section{POTENCJAŁ I WYKORZYSTANIE TURYSTYCZNEJ BAZY NOCLEGOWEJ WOJEWÓDZTWA EÓDZKIEGO}

\subsection{Zmiany w liczbie i pojemności turystycznej bazy noclegowej w województwie łódzkim}

Rozwój turystycznej bazy noclegowej w obecnym województwie łódzkim spowodowany był dużym zapotrzebowaniem (popytem) zamieszkującej go ludności miejskiej na różne formy wypoczynku. Przed II wojną światową mieszkańcy miast regionu, zwłaszcza Łodzi, organizowali w jego obszarze wypoczynek letniskowy, głównie w wynajmowanych kwaterach wiejskich, własnych domach letniskowych, a także pensjonatach, hotelach, obozowiskach. Po wojnie organizacja turystyki socjalnej w Polsce wymusiła konieczność uruchomienia, budowy i systematycznej rozbudowy ośrodków wczasowych, kolonijnych, szkoleniowo-wypoczynkowych, wypoczynku sobotnio-niedzielnego i świątecznego, domów pracy twórczej oraz obiektów obsługujących ruch krajoznawczy - domów wycieczkowych i schronisk. Turystyczna baza noclegowa obsługująca turystykę socjalną rozwijana była przez Fundusz Wczasów Pracowniczych (FWP), zakłady pracy, instytucje i organizacje społeczne. Na ogół dostępna była tylko dla określonych środowisk społecznych (stąd określano ją jako środowiskową lub zamkniętą). Duże nakłady finansowe jej gestorów w latach 1945-1989 sprawiły, że rozwinęła się w szybkim tempie. Natomiast o wiele mniej uwagi poświęcano rozwojowi turystyki komercyjnej, obsługiwanej przez tzw. otwarte obiekty turystycznej bazy noclegowej w postaci hoteli, moteli, zajazdów, pensjonatów, schronisk, kwater prywatnych, kempingów, pól namiotowych itp.

Lokalizacja obiektów turystycznej bazy noclegowej obsługująca wypoczynek pobytowy (wczasy) koncentrowała się na obszarach o wysokich walorach turystycznych (na wybrzeżu, nad jeziorami i rzekami, w okolicach górskich i wyżynnych) oraz na bliższym i dalszym zapleczu dużych aglomeracji miejsko-przemysłowych kraju (Rogalewska 1978). Z kolei wiele obiektów bazy noclegowej obsługującej turystykę krajoznawczą zlokalizowano w dużych miastach, ośrodkach historycznych i mających unikalne walory przyrodnicze. To wówczas, w okresie rozwoju turystyki socjalnej województwo łódzkie zyskało 
profesjonalne wyposażenie $\mathrm{w}$ turystyczną bazę noclegową. Zakłady pracy, instytucje i organizacje społeczne z województwa połowę wszystkich swoich inwestycji turystycznych lokowały na jego obszarze (Rogalewska 1978).

\subsubsection{Baza noclegowa w latach 1945-1989}

Województwo łódzkie miało (Bednarska, Musiał 1973) i nadal ma niewielki udział w zasobach turystycznej bazy noclegowej kraju. W 1972 roku udział miejsc wczasowych w bazie zamkniętej regionu wynosił 1,9\%, a w bazie noclegowej FWP - 0,25\%.

W 1970 roku ośrodki kolonijne dla dzieci i młodzieży w ówczesnym województwie lódzkim dysponowały liczbą 22,7 tys. miejsc noclegowych (co stanowiło blisko połowę ogółu rejestrowanych miejsc noclegowych w regionie). Lokowano je głównie w obiektach szkolnych (56\% miejsc) w okresie wakacji. Tylko szacunkowo 10 tys. miejsc było w obiektach noclegowych różnych instytucji i zakładów pracy. W większości ówczesnych powiatów (poza kutnowskim i łęczyckim) zlokalizowano ośrodki kolonijne. Większe skupiska były jednak na zapleczu Łodzi i w sąsiednich powiatach (łaskim, rawskim, piotrkowskim). $\mathrm{Z}$ kolei ośrodki wczasowe miały 7,3 tys. miejsc noclegowych. Ich udział w bazie noclegowej województwa sięgał 15,6\%, w tym FWP dysponowało 1152 miejscami, a pozostałe 6,1 tys. należało do związków zawodowych, różnych instytucji i zakładów pracy. Jednak $88 \%$ zakładowej bazy noclegowej dotyczyło domków kempingowych o dość niskim standardzie, wykorzystywanych tylko w sezonie letnim. W obiektach całorocznych FWP miał 689 miejsc noclegowych. Większe skupiska ośrodków wczasowych znajdowały się w dolinie Pilicy (blisko trzy czwarte ogółu miejsc noclegowych w regionie) w powiatach piotrkowskim, rawskim i skierniewickim (m.in. Sulejowie, Spale, Teofilowie, Inowłodzu, Nowym Mieście), na zapleczu Łodzi (z udziałem prawie 10\% miejsc noclegowych) w powiecie łódzkim (m.in. Grotnikach, Głownie, Kolumnie) i dolinie Warty (m.in. Budach Grabskich, Księżych Młynach, Uniejowie).

W 1970 roku w zasobach bazy noclegowej ówczesnego województwa łódzkiego duże znaczenie miały kwatery prywatne. Obsługiwały one indywidualny ruch letniskowy. Ich wielkość szacowano na 11,8 tys. miejsc noclegowych (co stanowiło prawie jedną czwartą wszystkich takich miejsc regionu tódzkiego). Znajdowały się one głównie w gospodarstwach chłopskich (ok. 86\%) i indywidualnych domach letniskowych. Większe skupiska były na bezpośrednim zapleczu Łodzi w ówczesnych powiatach łowickim, rawskim, skierniewickim.

W owym okresie region lódzki miał nader skromną bazę hotelową, liczącą zaledwie 1,3 tys. miejsc noclegowych (sama Łódź miała 835 miejsc, tj. $64 \%$ zasobów tej bazy w województwie). Miejsca noclegowe w hotelach stanowily zaledwie $2,7 \%$ całej bazy noclegowej ówczesnego województwa. Region dysponował 
też małym zasobem miejsc noclegowych w schroniskach turystycznych i domach wycieczkowych (ok. 2,5 tys.), z czego blisko połowa przypadała na schroniska młodzieżowe ulokowane w szkołach, czynne tylko w okresie wakacyjnym. Podobnie niewielką liczbą miejsc noclegowych dysponowały kempingi (817) i cztery stanice wodne (180). Łącznie ta część ogólnodostępnej bazy noclegowej liczyła w 1970 roku zaledwie 4,7 tys. miejsc (co stanowiło prawie 10\% całej bazy noclegowej w regionie) (Bednarska, Musiał 1973). Rozmieszczenie i strukturę bazy noclegowej w ówczesnym województwie łódzkim przedstawiono na rysunku 1.

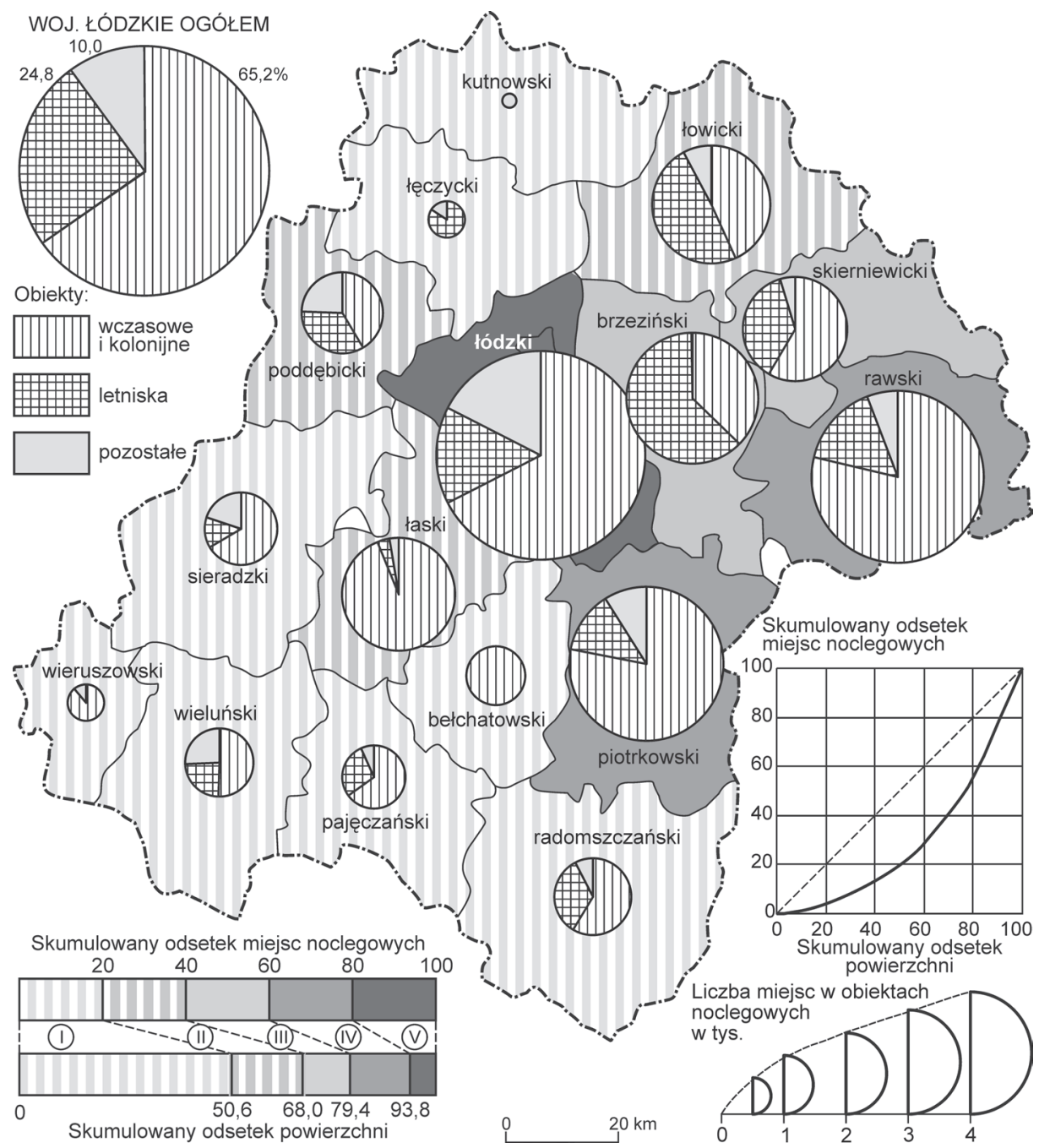

Rysunek 1. Baza noclegowa województwa łódzkiego w 1970 roku Źródło: opracowanie własne za: Bednarska, Musiał 1973 
Po 1970 roku w województwie podjęto wiele nowych i modernizacyjnych inwestycji w zakresie turystycznej bazy noclegowej, głównie w segmencie socjalnym, ale też komercyjnym. Oddanie do użytku dwóch sztucznych akwenów: Zalewu Sulejowskiego (1973) i zbiornika wodnego Jeziorsko (1986) stworzyło nowe walory turystyczne i poszerzyło możliwości lokalizacji kolejnych obiektów. Stan turystycznej bazy noclegowej województwa łódzkiego w latach 1970-1989 zilustrowano na podstawie danych z 1990 roku (tab. 3 i 4 ).

Tabela 3. Turystyczna baza noclegowa województwa lódzkiego na tle Polski w 1990 roku

\begin{tabular}{|c|c|c|c|c|c|c|}
\hline \multirow{2}{*}{$\begin{array}{c}\text { Obiekty } \\
\text { bazy noclegowej }\end{array}$} & \multicolumn{2}{|c|}{ Obiekty } & \multicolumn{2}{|c|}{$\begin{array}{c}\text { Miejsca noclegowe } \\
\text { ogółem }\end{array}$} & \multicolumn{2}{|c|}{$\begin{array}{l}\text { Miejsca noclegowe } \\
\text { całoroczne }\end{array}$} \\
\hline & $\begin{array}{l}\text { woj. } \\
\text { tódzkie }\end{array}$ & Polska & $\begin{array}{l}\text { woj. } \\
\text { tódzkie }\end{array}$ & Polska & $\begin{array}{c}\text { woj. } \\
\text { tódzkie }\end{array}$ & Polska \\
\hline 1 & 2 & 3 & 4 & 5 & 6 & 7 \\
\hline hotele & 27 & 499 & 2738 & 57396 & 2738 & 56875 \\
\hline motele & 2 & 37 & 87 & 2153 & 87 & 2153 \\
\hline pensjonaty & 3 & 161 & 549 & 6028 & 399 & 4732 \\
\hline $\begin{array}{l}\text { inne obiekty } \\
\text { hotelowe }\end{array}$ & 0 & 0 & 0 & 0 & 0 & 0 \\
\hline $\begin{array}{l}\text { Razem (obiekty } \\
\text { hotelarskie) }\end{array}$ & 32 & 697 & 3374 & 65577 & 3224 & 63760 \\
\hline domy wycieczkowe & 22 & 366 & 1191 & 24815 & 982 & 22035 \\
\hline schroniska ogółem & 40 & 1019 & 1297 & 39576 & 233 & 11152 \\
\hline hostele & 0 & 0 & 0 & 0 & 0 & 0 \\
\hline $\begin{array}{l}\text { Razem (domy wy- } \\
\text { cieczkowe, schro- } \\
\text { niska i hostele) }\end{array}$ & 62 & 1385 & 2488 & 64391 & 1215 & 33187 \\
\hline kempingi & 10 & 199 & 1246 & 43009 & 61 & 709 \\
\hline pola biwakowe & 10 & 390 & 720 & 71471 & 0 & 0 \\
\hline $\begin{array}{l}\text { Razem (kempingi } \\
\text { i pola biwakowe) }\end{array}$ & 20 & 589 & 1966 & 114480 & 61 & 709 \\
\hline
\end{tabular}




\begin{tabular}{|c|c|c|c|c|c|c|}
\hline 1 & 2 & 3 & 4 & 5 & 6 & 7 \\
\hline $\begin{array}{l}\text { ośrodki wypoczyn- } \\
\text { ku sobotnio-nie- } \\
\text { dzielnego i świą- } \\
\text { tecznego } \\
\text { oraz zespoły dom- } \\
\text { ków turystycznych }\end{array}$ & 16 & 519 & 928 & 33741 & 172 & 2003 \\
\hline $\begin{array}{l}\text { ośrodki wczasowe } \\
\text { i kolonijne }\end{array}$ & 125 & 4238 & 7663 & 318454 & 995 & 62704 \\
\hline $\begin{array}{l}\text { ośrodki szkolenio- } \\
\text { wo-wypoczynkowe }\end{array}$ & 12 & 422 & 923 & 40290 & 562 & 20710 \\
\hline $\begin{array}{l}\text { domy pracy twór- } \\
\text { czej }\end{array}$ & 2 & 51 & 122 & 2098 & 82 & 1773 \\
\hline $\begin{array}{l}\text { zakłady } \\
\text { uzdrowiskowe }\end{array}$ & 0 & 104 & 0 & 17982 & 0 & 4734 \\
\hline $\begin{array}{l}\text { Razem (ośrodki } \\
\text { wypoczynkowe) }\end{array}$ & 155 & 5334 & 9636 & 412565 & 1811 & 91924 \\
\hline pokoje gościnne & 11 & 724 & 360 & 66786 & 336 & 13975 \\
\hline $\begin{array}{l}\text { kwatery agrotury- } \\
\text { styczne }\end{array}$ & 0 & 0 & 0 & 0 & 0 & 0 \\
\hline $\begin{array}{l}\text { pozostałe obiekty } \\
\text { niesklasyfikowane }\end{array}$ & 4 & 186 & 789 & 19259 & 0 & 9605 \\
\hline $\begin{array}{l}\text { Razem (obiekty } \\
\text { zakwaterowania } \\
\text { indywidualnego) }\end{array}$ & 15 & 910 & 1149 & 86045 & 336 & 23580 \\
\hline Ogółem & 284 & 8915 & 18613 & 743058 & 6647 & 213160 \\
\hline
\end{tabular}

Źródło: opracowanie własne za: Turystyka w 1990 roku 1991. 
Tabela 4. Struktura rodzajowa turystycznej bazy noclegowej województwa łódzkiego i Polski w 1990 roku (w \%)

\begin{tabular}{|c|c|c|c|c|c|c|}
\hline \multirow{2}{*}{$\begin{array}{c}\text { Obiekty } \\
\text { bazy noclegowej }\end{array}$} & \multicolumn{2}{|c|}{ Obiekty } & \multicolumn{2}{|c|}{$\begin{array}{c}\text { Miejsca } \\
\text { noclegowe } \\
\text { ogółem }\end{array}$} & \multicolumn{2}{|c|}{$\begin{array}{c}\text { Miejsca } \\
\text { noclegowe } \\
\text { całoroczne }\end{array}$} \\
\hline & $\begin{array}{l}\text { woj. } \\
\text { lódzkie }\end{array}$ & Polska & $\begin{array}{l}\text { woj. } \\
\text { lódzkie }\end{array}$ & Polska & $\begin{array}{l}\text { woj. } \\
\text { łódzkie }\end{array}$ & Polska \\
\hline 1 & 2 & 3 & 4 & 5 & 6 & 7 \\
\hline hotele & 9,5 & 5,6 & 14,7 & 7,7 & 41,2 & 26,7 \\
\hline motele & 0,7 & 0,4 & 0,5 & 0,3 & 1,3 & 1,0 \\
\hline pensjonaty & 1,1 & 1,8 & 2,9 & 0,8 & 6,0 & 2,2 \\
\hline inne obiekty hotelowe & 0 & 0 & 0 & 0 & 0 & 0 \\
\hline $\begin{array}{l}\text { Razem (obiekty } \\
\text { hotelarskie) }\end{array}$ & 11,3 & 7,8 & 18,1 & 8,8 & 48,5 & 29,9 \\
\hline domy wycieczkowe & 7,7 & 4,1 & 6,4 & 3,3 & 14,8 & 10,4 \\
\hline schroniska ogółem & 14,1 & 11,4 & 7,0 & 5,3 & 3,5 & 5,2 \\
\hline hostele & 0 & 0 & 0 & 0 & 0 & 0 \\
\hline $\begin{array}{l}\text { Razem (domy } \\
\text { wycieczkowe, } \\
\text { schroniska i hostele) }\end{array}$ & 21,8 & 15,5 & 13,4 & 8,6 & 18,3 & 15,6 \\
\hline kempingi & 3,5 & 2,2 & 6,7 & 5,8 & 0,9 & 0,3 \\
\hline pola biwakowe & 3,5 & 4,4 & 3,9 & 9,6 & 0 & 0 \\
\hline $\begin{array}{l}\text { Razem (kempingi } \\
\text { i pola biwakowe) }\end{array}$ & 7,0 & 6,6 & 10,6 & 15,4 & 0,9 & 0,3 \\
\hline $\begin{array}{l}\text { ośrodki wypoczynku } \\
\text { sobotnio-niedzielnego } \\
\text { i świątecznego oraz } \\
\text { zespoły domków } \\
\text { turystycznych }\end{array}$ & 5,6 & 5,8 & 5,0 & 4,6 & 2,6 & 1,0 \\
\hline $\begin{array}{l}\text { ośrodki wczasowe } \\
\text { i kolonijne }\end{array}$ & 44,0 & 47,5 & 41,2 & 42,9 & 15,0 & 29,4 \\
\hline $\begin{array}{l}\text { ośrodki szkoleniowo- } \\
\text {-wypoczynkowe }\end{array}$ & 4,2 & 4,7 & 5,0 & 5,4 & 8,5 & 9,7 \\
\hline
\end{tabular}




\begin{tabular}{|l|r|r|r|r|r|r|}
\hline \multicolumn{1}{|c|}{1} & \multicolumn{1}{c|}{2} & \multicolumn{1}{c|}{3} & \multicolumn{1}{c|}{4} & \multicolumn{1}{c|}{5} & \multicolumn{1}{c|}{6} & \multicolumn{1}{c|}{7} \\
\hline domy pracy twórczej & 0,7 & 0,6 & 0,6 & 0,3 & 1,2 & 0,8 \\
\hline zakłady uzdrowiskowe & 0 & 1,2 & 0 & 2,4 & 0 & 2,2 \\
\hline $\begin{array}{l}\text { Razem (ośrodki } \\
\text { wypoczynkowe) }\end{array}$ & $\mathbf{5 4 , 5}$ & $\mathbf{5 9 , 9}$ & $\mathbf{5 1 , 8}$ & $\mathbf{5 5 , 6}$ & $\mathbf{2 7 , 3}$ & $\mathbf{4 3 , 1}$ \\
\hline pokoje gościnne & 3,9 & 8,1 & 1,9 & 9,0 & 5,0 & 6,6 \\
\hline $\begin{array}{l}\text { kwatery } \\
\text { agroturystyczne }\end{array}$ & 0 & 0 & 0 & 0 & 0 & 0 \\
\hline $\begin{array}{l}\text { pozostałe obiekty } \\
\text { niesklasyfikowane }\end{array}$ & 1,5 & 2,1 & 4,2 & 2,6 & 0 & 4,5 \\
\hline $\begin{array}{l}\text { Razem (obiekty } \\
\text { zakwaterowania } \\
\text { indywidualnego) }\end{array}$ & $\mathbf{5 , 4}$ & $\mathbf{1 0 , 2}$ & $\mathbf{6 , 1}$ & $\mathbf{1 1 , 6}$ & $\mathbf{5 , 0}$ & $\mathbf{1 1 , 1}$ \\
\hline \begin{tabular}{l} 
Razem \\
\hline
\end{tabular} & 100,0 & 100,0 & 100,0 & 100,0 & 100,0 & 100,0 \\
\hline
\end{tabular}

Źródło: opracowanie własne za: Turystyka w 1990 roku 1991.

W 1990 roku województwo łódzkie dysponowało 284 obiektami turystycznej bazy noclegowej z 18,6 tys. miejsc noclegowych ogółem. Blisko dwie trzecie z nich wykorzystywano tylko sezonowo. Miejsc całorocznych było 6,65 tys. Udział turystycznych obiektów noclegowych województwa w liczbie i pojemności takich obiektów w Polsce był wówczas niewielki. Region łódzki miał 1,5\% liczby obiektów turystycznej bazy noclegowej całego kraju, miejsc noclegowych ogółem 2,5\%, a całorocznych 3,1\%. Szczególnie niski był w wypadku obiektów obsługujących wczasy i kolonie (odpowiednio: 2,9\%, $2,4 \%$ i $1,6 \%)$, a nieco wyższy w udziale hoteli (5,4\%, 4,8\% i 4,8\%).

Najliczniej reprezentowane były ośrodki wczasowe i kolonijne w liczbie 125 (stanowiąc 44\% ogółu obiektów bazy noclegowej województwa). Dysponowały 7663 miejscami noclegowymi $(41,2 \%)$, z których blisko tysiąc użytkowano przez cały rok (15\% ogółu miejsc całorocznych). Były one stosunkowo duże i liczyły przeciętnie 61 miejsc noclegowych. Dołączając do nich pozostałe obiekty noclegowe obsługujące wypoczynek organizowany przez zakłady pracy, różne instytucje i organizacje społeczno-ekonomiczne ich liczba wzrasta do 155, osiągając blisko 9 tys. miejsc, w tym niemal 1,6 tys. całorocznych. Pod względem liczby i pojemności stanowily one w 1990 roku nieco ponad połowę całej bazy noclegowej województwa. Drugą liczną grupę stanowiły obiekty noclegowe obsługujące turystykę wycieczkową, zwłaszcza młodzieżową, w postaci 
domów wycieczkowych i schronisk. Łącznie były to 62 obiekty, z prawie 2,5 tys. miejsc noclegowych, w tym nieco ponad 1,2 tys. całorocznymi. Były to jednak obiekty o mniejszych rozmiarach (przeciętnie z 40 miejscami), stąd ich całkowita pojemność była mniejsza niż hoteli. Tych było zaledwie $27 \mathrm{w}$ województwie, ale ogólem miały ponad 2,7 tys. miejsc noclegowych, użytkowanych przez cały rok (41,2\% takich miejsc w regionie). Były to obiekty duże, średnio z nieco ponad 100 miejscami. Dołączając do nich motele i pensjonaty, wielkość bazy hotelarskiej regionu wzrastała do 32 obiektów, z blisko 3,4 tys. miejscami noclegowymi, w tym 3,2 tys. całorocznymi. Uzupełnienie zasobów bazy noclegowej w województwie stanowiły kempingi i pola biwakowe. Łącznie było ich 20 , z blisko 2 tys. miejsc noclegowych. Obiekty te działały niemal wyłącznie sezonowo (miały zaledwie 61 miejsc całorocznych). Wspomniane kategorie obiektów turystycznych zbiorowego zakwaterowania rejestrowane były przez statystykę państwową w niemal pełnym zakresie. Odmiennie, niż indywidualne obiekty zakwaterowania turystycznego w postaci pokoi gościnnych, kwater agroturystycznych i pozostałych obiektów niesklasyfikowanych, które dość powszechnie nie dopełniały obowiązku rejestracji statystycznej. Stąd też według statystyk GUS-owskich ich udział w bazie noclegowej województwa był marginalny, na poziomie około $5 \%$ liczby obiektów i ich pojemności. Z obserwacji terenowych wynika, że ta kategoria bazy noclegowej miała i nadal ma ważny udział w obsłudze ruchu turystycznego w województwie. W 2016 roku szacowano, że blisko połowę ruchu turystycznego na jego obszarze obsługiwała ta właśnie baza (Włodarczyk 2017: 92).

Przedstawiona struktura rodzajowa turystycznej bazy noclegowej województwa łódzkiego w 1990 roku zbliżona była do ogólnokrajowej. W województwie łódzkim dużo wyższe udziały niż w Polsce miały hotele i pozostałe obiekty hotelarskie wraz z domami wycieczkowymi i schroniskami. Natomiast udział miejsc noclegowych w obiektach wczasowych obsługujących turystykę pobytową był niższy w porównaniu z krajowym (tab. 3 i 4).

Dane statystyczne umożliwiają analizę rozmieszczenia liczby i pojemności obiektów turystycznej bazy noclegowej w granicach obecnego województwa łódzkiego według powiatów dopiero od 1995 roku. W opracowaniu ten właśnie rok przyjęto jako kończący (w pewnym przybliżeniu) okres turystyki socjalnej. Biorąc pod uwagę liczbę obiektów noclegowych w województwie w tymże roku można wyodrębnić trzy niemal równorzędne zgrupowania tych obiektów. W skład pierwszego z nich wchodziła Łódź i przyległe do niej powiaty: łódzki wschodni, pabianicki i zgierski, które łącznie miały jedną czwartą ogółu obiektów noclegowych w całym województwie. Drugie zgrupowanie obiektów noclegowych zlokalizowane było w powiatach nadpilicznych (Piotrkowie Trybunalskim, piotrkowskim, tomaszowskim, rawskim). Skupiało ono nieco ponad 
jedną czwartą ogólu obiektów noclegowych w województwie. Na tym obszarze duże znaczenie dla ich lokalizacji miało utworzenie w 1973 roku Zalewu Sulejowskiego na Pilicy. Na jego zapleczu do końca lat 80. zeszłego wieku zlokalizowano kilka ośrodków wypoczynkowych, a w okolicznych wsiach uruchomiono kwatery prywatne i zbudowano wiele tzw. drugich domów. Trzecie zgrupowanie obiektów noclegowych objęło powiaty nadwarciańskie (wieluński, sieradzki, poddębicki), w obrębie których zlokalizowano blisko jedną piątą obiektów noclegowych w województwie. Utworzony tam w 1986 roku (głównie dla celów rolniczych) zbiornik Jeziorsko na Warcie nie przyciągnął większych inwestycji w zakresie bazy noclegowej. Łącznie te trzy zgrupowania dysponowały w 1995 roku nieco ponad dwoma trzecimi ogółu obiektów noclegowych zlokalizowanych w obecnym województwie łódzkim. Natomiast blisko jedna trzecia obiektów noclegowych była rozproszona w pozostałej jego części ( $\mathrm{z}$ wyłączeniem powiatów kutnowskiego i łęczyckiego, gdzie oficjalnie nie zarejestrowano w 1995 roku żadnego obiektu). Rozmieszczenie wielkości i strukturę (obiekty całoroczne i sezonowe) bazy noclegowej przedstawiono na rysunku 2.

Wskaźnik koncentracji ${ }^{1}$ obliczony dla miejsc noclegowych ogólem osiągnął wysoką wartość $\eta=0,542$. W trzech wyodrębnionych wyżej zgrupowaniach bazy noclegowej znalazło się 80,5\% ogółu miejsc noclegowych zlokalizowanych w województwie. Łódź i graniczące z nią powiaty miały $33,8 \%$ całej pojemności bazy noclegowej $\mathrm{w}$ regionie. $Z$ kolei powiaty nadpiliczne dalsze $30,5 \%$. Natomiast udział powiatów nadwarciańskich był mniejszy, na poziomie $16,2 \%$. W trzech zgrupowaniach przeciętna pojemność obiektu noclegowego była stosunkowo wysoka. W Łodzi i na jej zapleczu obiekt noclegowy miał średnio 103 miejsca (decydował o tym duży udział hoteli zlokalizowanych w mieście). W powiatach nadpilicznych był niewiele niższy i wynosił średnio 96,8 miejsca na obiekt (były to ośrodki wczasowe i hotele). Z kolei w powiatach nadwarciańskich obiekty były mniejsze, średnio jeden miał 82,8 miejsca. W pozostałej części województwa obiekty noclegowe były przeciętnie mniejszych rozmiarów.

1 Wskaźnik koncentracji Lorenza $(\eta)$ dotyczy pomiaru proporcjonalnego występowania par zmiennych. Jedną z nich jest powierzchnia powiatów (w województwie łódzkim), drugą liczba turystycznych miejsc noclegowych zlokalizowanych na ich obszarze. Maksymalna koncentracja $(\eta=1)$ oznacza wyłączną lokalizacje miejsc noclegowych w jednym powiecie, minimalna $(\eta=0)$ proporcjonalny udział miejsc noclegowych w stosunku do powierzchni powiatów, zatem $0 \leq \eta \leq 1$ (zob. Jokiel, Kostrubiec 1981: 242-245). 


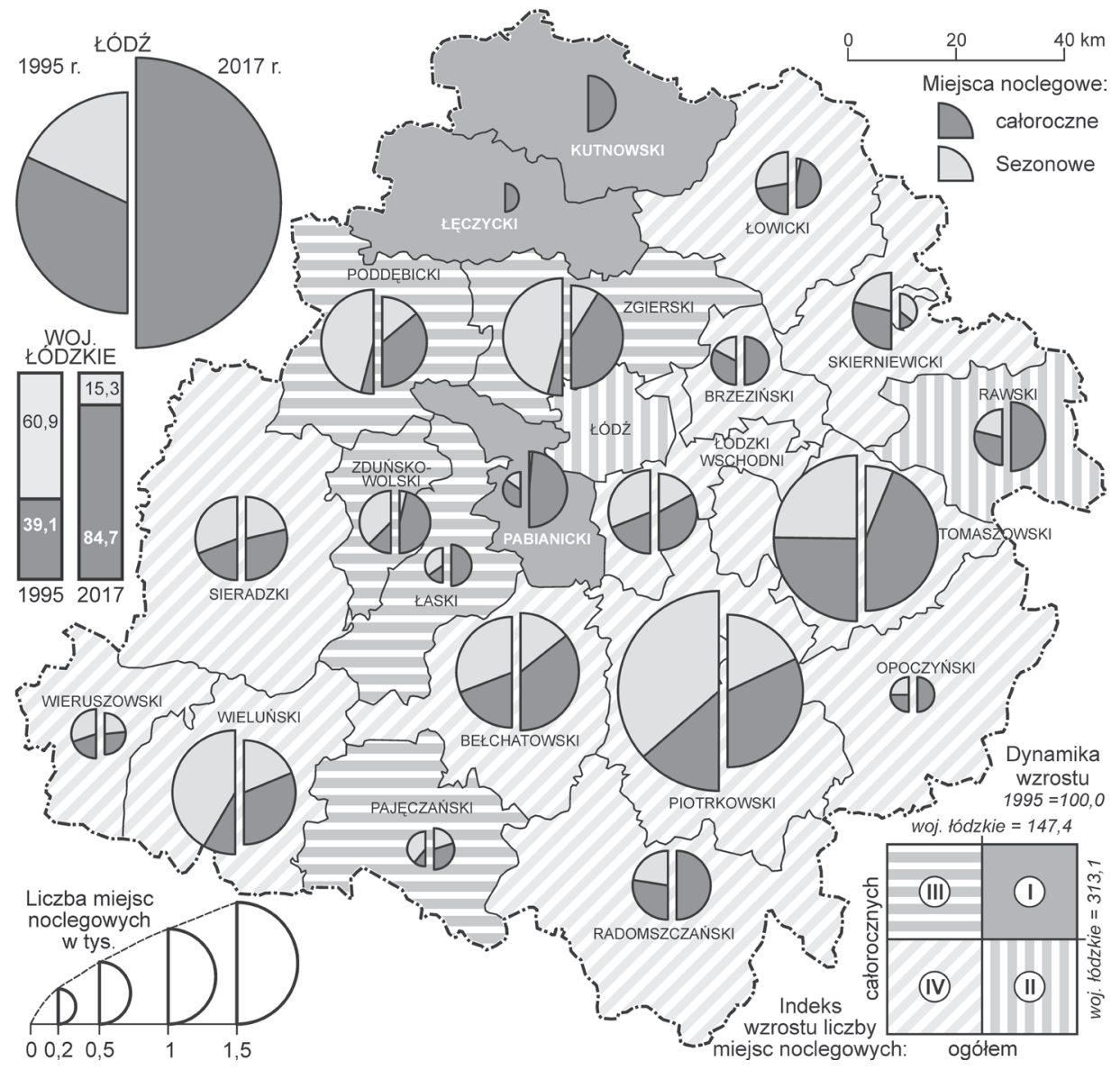

Rysunek 2. Rozmieszczenie i dynamika wzrostu pojemności turystycznych obiektów noclegowych w regionie łódzkim w latach 1995 i 2017

Źródło: opracowanie własne za: Bank Danych Lokalnych, https://www.bdl.stat.gov.pl (dostęp: 20.03.2018)

Podobnie wysokie skupienie w województwie łódzkim w 1995 roku miały całoroczne miejsca noclegowe. Udział Łodzi wraz z powiatami bezpośrednio z nią sąsiadującymi sięgał 38,4\% ogółu takich miejsc. Przy czym w samym mieście było to $32,7 \%$, a w pozostałych trzech powiatach zaledwie $6,2 \%$. Powiaty nadpiliczne miały dalsze $29,8 \%$ całorocznych miejsc noclegowych w województwie. Natomiast nadwarciańskie zaledwie 7,8\%. Pozostałe 23,5\% całorocznych miejsc noclegowych rozproszone było w 13 powiatach.

W tymże roku udział całorocznych miejsc w pojemności bazy noclegowej województwa sięgał 39,1\% i był na jego obszarze zróżnicowany. Najwyższy udział miejsca całoroczne miały w Łodzi i sąsiednich powiatach, gdzie stanowiły 
dwie trzecie całkowitej pojemności bazy noclegowej ( $\mathrm{z}$ wyjątkiem powiatu zgierskiego, gdzie wynosił on tylko $8,1 \%$ ). W powiatach nadpilicznych miejsca takie miały również wysoki udział w pojemności bazy noclegowej na poziomie powyżej 50\% (z wyjątkiem powiatu piotrkowskiego - 12,5\% udziału). Z kolei w powiatach nadwarciańskich ich udział był niski, znacznie poniżej średniej dla regionu. W pozostałych powiatach udział miejsc całorocznych oscylował wokół średniej dla województwa.

Rozmieszczenie poszczególnych rodzajów obiektów turystycznej bazy noclegowej w województwie łódzkim w 1995 roku było wyraźnie zróżnicowane. Obiekty hotelarskie wykazywały duże skupienie przestrzenne. Wskaźnik koncentracji przestrzennej ich pojemności wynosił 0,811. Udział Łodzi był tu dominujący $(48,5 \%)$. Dalsze pięć powiatów (Piotrków Trybunalski wraz z powiatem piotrkowskim i powiaty bełchatowski, rawski, tomaszowski) miało łącznie $26 \%$ pojemności obiektów hotelarskich. W obrębie obiektów hotelarskich dominowały hotele. Łódź dysponowała blisko dwoma trzecimi ogółu miejsc hotelowych w województwie, a wyżej wymienione obszary dalszymi 39,3\% ich pojemności. W rezultacie wskaźnik koncentracji pojemności hoteli wyniósł 0,862 . Podobnie wysoką koncentrację przestrzenną miały w województwie kwatery prywatne i pozostałe obiekty noclegowe niesklasyfikowane $(0,826)$. Znajdowały się one głównie w Łodzi (63,3\% takich miejsc noclegowych w województwie - w postaci pokoi gościnnych) i powiatach bezpośrednio $\mathrm{z}$ nią sąsiadujących $(7,1 \%)$. Udział powiatów nadpilicznych wynosił $11,2 \%$, a nadwarciańskich 3,5\%. Pozostałe $14,9 \%$ znajdowało się głównie w takich powiatach jak łowicki, opoczyński, radomszczański, wieruszowski. Pozostałe rodzaje obiektów bazy noclegowej w województwie łódzkim charakteryzowały się już mniejszymi wartościami wskaźnika koncentracji. Dla ośrodków wypoczynkowych wynosił on 0,567. Największą liczbę miejsc w ośrodkach wypoczynkowych miały powiaty nadpiliczne $(31,8 \%)$, podłódzkie $(25,9 \%)$ i nadwarciańskie $(24,1 \%)$. Pozostałe 18,2\% miejsc w ośrodkach wypoczynkowych rozproszone było w dalszych ośmiu powiatach. Podobną wartość wskaźnika koncentracji miały domy wycieczkowe i schroniska $(0,609)$. Obiekty te były skupione głównie w Łodzi $(22,5 \%)$, Piotrkowie Trybunalskim i powiecie piotrkowskim (18,9\%), poddębickim (10\%) i radomszczańskim (9,5\%). Zbliżoną wartość wskaźnika koncentracji miały kempingi i pola biwakowe $(0,62)$, jednak odmienny rozkład przestrzenny. Najwięcej miejsc na kempingach i polach biwakowych było w powiecie piotrkowskim $(27,8 \%)$, poddębickim $(15,5 \%)$, bełchatowskim $(13,2 \%)$, tomaszowskim $(11,6 \%)$ i wieluńskim $(8,5 \%)$. 


\begin{tabular}{|c|c|c|c|c|c|c|c|c|c|c|c|c|c|c|}
\hline \multirow{2}{*}{$\begin{array}{l}\text { हี } \\
\text { సี } \\
\text { हี }\end{array}$} & $\alpha^{0}$ & $\stackrel{m}{n}$ & $\stackrel{0}{\circ}$ & $\stackrel{0}{\circ}$ & $\stackrel{0}{\circ} \stackrel{0}{\circ}$ & 웅 & $\stackrel{0}{\circ} \stackrel{-}{\circ}$ & $\begin{array}{l}0 \\
0 \\
0\end{array}$ & $\stackrel{0}{\circ}$ & $\begin{array}{l}0 \\
0 \\
0 \\
0\end{array}$ & $\stackrel{\circ}{\circ} \stackrel{\circ}{\circ}^{-}$ & $\begin{array}{l}0 \\
8 \\
0 \\
0\end{array}$ & 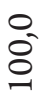 & $\stackrel{0}{\circ}$ \\
\hline & 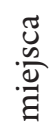 & $\stackrel{\sim}{\sim}$ & $\stackrel{\text { ले }}{=}$ & ஜ & 0 & \pm & 0 & $\stackrel{m}{\ddagger}$ & $\underset{\infty}{ \pm}$ & $\vec{a}$ & $\hat{\sigma}$ & $\approx$ & $\begin{array}{l}+ \\
\infty \\
\text { m}\end{array}$ & $\begin{array}{l}\text { ก } \\
\text { ב }\end{array}$ \\
\hline \multirow{2}{*}{ 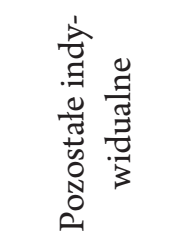 } & $\alpha^{0}$ & 二 & $\begin{array}{l}0 \\
i n\end{array}$ & 0 & 0 & 0 & 0 & $\stackrel{t}{\sigma}$ & $\stackrel{n}{\sim}$ & $\hat{m}^{\infty}$ & $\hat{n}$ & 0 & $\approx$ & $\tilde{0}$ \\
\hline & 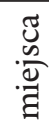 & 윽 & t & 0 & 0 & 0 & 0 & $\stackrel{\text { }}{\sim}$ & $\stackrel{\partial}{ }$ & 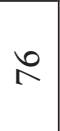 & $\tilde{b}$ & 0 & 吕 & 6 \\
\hline \multirow{2}{*}{ 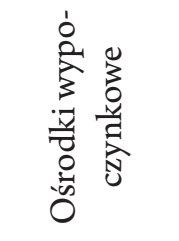 } & $\alpha^{0}$ & $a$ & 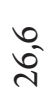 & 0 & 0 & $\hat{a}$ & 0 & 0 & $\vec{\infty}$ & 0 & $\begin{array}{l}n \\
\tilde{n} \\
\tilde{n}\end{array}$ & $\hat{\infty}^{-}$ & बे & $\vec{m}$ \\
\hline & 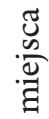 & $\infty$ & ?ి & 0 & 0 & $\infty$ & 0 & 0 & $\frac{0}{6}$ & 0 & $\bar{n}$ & $\stackrel{n}{\simeq}$ & $\begin{array}{l}\text { 을 } \\
\stackrel{n}{\sim}\end{array}$ & ñ \\
\hline \multirow{2}{*}{ 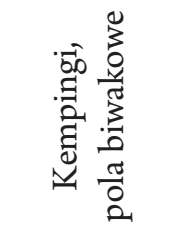 } & $\alpha^{0}$ & $\Lambda$ & $\stackrel{\infty}{\mathbb{f}^{-}}$ & 0 & 0 & 0 & 0 & ิㅡㅁ & $\stackrel{\infty}{-}$ & $\stackrel{n}{m}$ & 0 & 0 & $\stackrel{a}{m}$ & $\begin{array}{l}0 \\
n \\
n\end{array}$ \\
\hline & 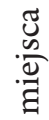 & 6 & $\stackrel{0}{i n}$ & 0 & 0 & 0 & 0 & 윽 & $\approx$ & 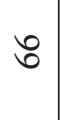 & 0 & 0 & $\begin{array}{l}\infty \\
\hat{0}\end{array}$ & 8 \\
\hline \multirow{2}{*}{ 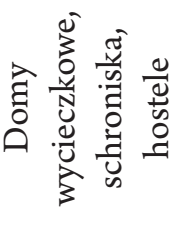 } & $\alpha^{0}$ & $n$ & స & 옹 & 0 & 0 & 0 & $\stackrel{\sqrt{n}}{\tilde{N}}$ & $\begin{array}{l}0 \\
6\end{array}$ & $\vec{n}$ & 0 & $\begin{array}{l}n \\
0^{\prime}\end{array}$ & $\hat{\sigma}$ & $\begin{array}{l}+ \\
\stackrel{n}{n}\end{array}$ \\
\hline & 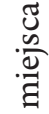 & 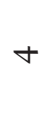 & $\approx$ & 요 & 0 & 0 & 0 & 士 & 字 & 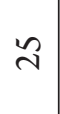 & 0 & 이 & $\stackrel{\infty}{\sim}$ & $\stackrel{ \pm}{ \pm}$ \\
\hline \multirow{2}{*}{ 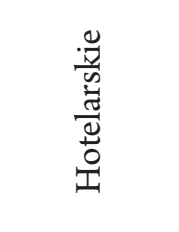 } & $\alpha^{0}$ & $m$ & $\begin{array}{l}\infty \\
0^{-}\end{array}$ & 0 & 0 & ?2 & 0 & 0 & $\infty^{\infty}$ & $\begin{array}{l}0 \\
\mathfrak{J}\end{array}$ & $\stackrel{\infty}{-1}$ & 0 & $\stackrel{0}{=}$ & 0 \\
\hline & $\frac{\tilde{U}}{\mathscr{D}} \cdot \frac{\mathscr{d}}{\mathbb{Z}}$ & $N$ & $\hat{\sim}$ & 0 & 0 & $\stackrel{\infty}{n}$ & 0 & 0 & $\approx$ & $\stackrel{d}{\sim}$ & $\tilde{n}$ & 0 & $\stackrel{n}{n}$ & 0 \\
\hline $\begin{array}{l}\frac{\pi}{3} \\
. \\
0 \\
0\end{array}$ & & $\neg$ & $\begin{array}{l}\frac{7}{0} \\
\overline{0} \\
0 \\
0 \\
0 \\
\frac{1}{0} \\
\frac{0}{0} \\
0\end{array}$ & 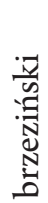 & 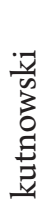 & $\frac{\vec{n}}{\tilde{g}}$ & 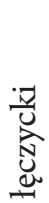 & 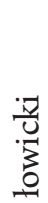 & 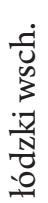 & 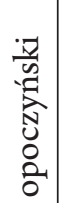 & 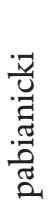 & 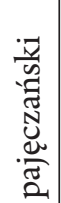 & 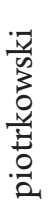 & 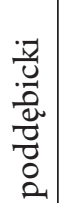 \\
\hline
\end{tabular}


Potencjał i wykorzystanie turystycznej bazy noclegowej...

\begin{tabular}{|c|c|c|c|c|c|c|c|c|c|c|c|}
\hline 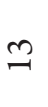 & 웅 & $\stackrel{0}{8}$ & 웅 & $\stackrel{\circ}{\circ}$ & $\stackrel{0}{8}$ & $\stackrel{0}{8}$ & 웅 & $\begin{array}{l}0 \\
8 \\
8\end{array}$ & $\begin{array}{l}0 \\
8 \\
8 \\
-1\end{array}$ & $\begin{array}{l}0 \\
\stackrel{0}{0} \\
\bigcirc\end{array}$ & 웅 \\
\hline$\stackrel{\sim}{工}$ & $\begin{array}{l}\text { b } \\
\text { in }\end{array}$ & $\begin{array}{l}m \\
\infty \\
m\end{array}$ & $\stackrel{+}{N}$ & ஜ̊ & $\underset{N}{\stackrel{\infty}{N}}$ & $\begin{array}{l}0 \\
\text { ñ }\end{array}$ & $\underset{m}{\tilde{m}}$ & $\underset{\sim}{\infty}$ & $\begin{array}{l}\text { ̊ } \\
\text { ले }\end{array}$ & 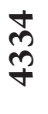 & $\begin{array}{l}m \\
\infty \\
a \\
a\end{array}$ \\
\hline$\beth$ & $\stackrel{0}{a}$ & 0 & 0 & $\underset{-}{ \pm}$ & $\stackrel{+}{\dot{\pi}}$ & $\stackrel{\infty}{0}$ & $\stackrel{+}{\text { ปे }}$ & $\stackrel{\infty}{\sim}$ & $\underset{\Xi}{ \pm}$ & $\ddot{n}$ & $\begin{array}{l}0 \\
n \\
n\end{array}$ \\
\hline 으 & $\stackrel{2}{0}$ & 0 & 0 & $\Lambda$ & $\stackrel{\infty}{\Gamma}$ & 으 & 으 & $\infty$ & ڤે & $\begin{array}{l}\infty \\
\infty \\
\infty\end{array}$ & ヘ̂ \\
\hline$a$ & $\begin{array}{r}\text { - } \\
\text { m }\end{array}$ & 0 & $\begin{array}{l}0 \\
0 \\
0 \\
0\end{array}$ & $\stackrel{0}{i}$ & $\stackrel{b}{\tilde{g}}$ & $\frac{a}{6}$ & $\approx$ & $\begin{array}{l}0 \\
\stackrel{n}{n}\end{array}$ & $\begin{array}{l}0 \\
\infty \\
\infty\end{array}$ & $\vec{m}$ & $\hat{n}$ \\
\hline$\infty$ & 志 & 0 & ষ্ & స్ర & ন & ন & 우 & 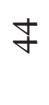 & $\begin{array}{l}\vec{\infty} \\
=\end{array}$ & $\ddot{n}$ & 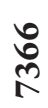 \\
\hline$\Lambda$ & 0 & $\begin{array}{l}0 \\
0^{-} \\
m\end{array}$ & $\stackrel{n}{\sim}$ & 0 & $\stackrel{\infty}{\sigma^{\prime}}$ & $\stackrel{n}{\stackrel{n}{\sim}}$ & $\stackrel{\sim}{\tilde{g}}$ & $\stackrel{0}{n^{n}}$ & $\begin{array}{l}0 \\
n^{-}\end{array}$ & 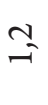 & $\ddot{a}$ \\
\hline 6 & 0 & $\stackrel{\circ}{ \pm}$ & ๙ & 0 & $\vec{n}$ & î & $\stackrel{\circ}{n}$ & in & in & 요 & $\begin{array}{l}\stackrel{R}{R} \\
\infty \\
\text { m }\end{array}$ \\
\hline$n$ & $\begin{array}{l}\infty \\
0 \\
\infty \\
\infty\end{array}$ & $\hat{n}$ & $\tilde{a}$ & $\underline{I}$ & $\vec{m}$ & $\stackrel{n}{f}$ & 0 & $\begin{array}{l}0 \\
\stackrel{\infty}{N} \\
\stackrel{0}{0}\end{array}$ & 0 & 으 & $\begin{array}{l}\infty \\
\infty\end{array}$ \\
\hline$\forall$ & $\approx 0$ & $\stackrel{\sim}{N}$ & $\infty$ & 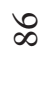 & a & $\stackrel{\infty}{n}$ & 0 & $\vec{\infty}$ & 0 & बे & $\stackrel{n}{n}$ \\
\hline$m$ & $\stackrel{+}{n}$ & $\hat{n}$ & $\stackrel{\infty}{a^{\prime}}$ & $\tilde{a}$ & $\overrightarrow{0}$ & $\widehat{\mathrm{N}}$ & $\stackrel{a}{n}$ & 0 & 0 & $\stackrel{\sim}{\tilde{f}}$ & 2 \\
\hline$N$ & $\stackrel{N}{N}$ & $\vec{入}$ & $N$ & $\stackrel{\infty}{+}$ & $\begin{array}{l}\circ \\
\$ 0\end{array}$ & $\hat{m}$ & $i n$ & 0 & 0 & $\underset{\infty}{+}$ & $\begin{array}{l}n \\
6 \\
\infty \\
\infty\end{array}$ \\
\hline$\neg$ & 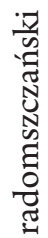 & 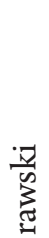 & $\frac{\frac{\pi}{N}}{\frac{\pi}{0}} \frac{\pi}{d}$ & 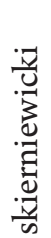 & 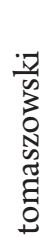 & $\frac{\sqrt{7}}{\sqrt{3}}$ & 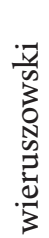 & 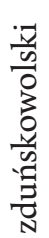 & 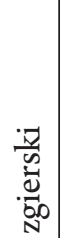 & 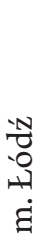 & 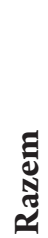 \\
\hline
\end{tabular}


Przedstawione rozmieszczenie poszczególnych rodzajów turystycznych obiektów noclegowych w województwie łódzkim w 1995 roku wskazuje, że w większości powiatów reprezentowane były wszystkie (pięć grup) lub prawie wszystkie (cztery) ich rodzaje (tab. 5). Jedynie w dziewięciu powiatach zlokalizowano trzy lub mniej grup rodzajów bazy noclegowej.

\subsubsection{Turystyczna baza noclegowa po 1990 roku}

Po 1990 roku zmiany w liczbie i pojemności turystycznej bazy noclegowej w województwie łódzkim miały podobny charakter jak zmiany zachodzące $\mathrm{w}$ całym kraju. W początkowym okresie transformacji ustrojowo-gospodarczej wystąpił wyraźny trend spadkowy zarówno w liczbie obiektów, jak i liczbie miejsc noclegowych ogółem. Wzrost liczby obiektów noclegowych i ich pojemności w województwie nastąpił dopiero w połowie pierwszej dekady XXI wieku.

Tabela 6. Turystyczna baza noclegowa województwa łódzkiego na tle Polski w 2017 roku

\begin{tabular}{|c|c|c|c|c|c|c|}
\hline \multirow{2}{*}{$\begin{array}{c}\text { Klasyfikacja } \\
\text { turystycznej } \\
\text { bazy noclegowej }\end{array}$} & \multicolumn{2}{|c|}{ Obiekty } & \multicolumn{2}{|c|}{$\begin{array}{l}\text { Miejsca noclegowe } \\
\text { ogółem }\end{array}$} & \multicolumn{2}{|c|}{$\begin{array}{l}\text { Miejsca noclegowe } \\
\text { całoroczne }\end{array}$} \\
\hline & $\begin{array}{l}\text { woj. } \\
\text { tódzkie }\end{array}$ & Polska & $\begin{array}{c}\text { woj. } \\
\text { tódzkie }\end{array}$ & Polska & $\begin{array}{c}\text { woj. } \\
\text { lódzkie }\end{array}$ & Polska \\
\hline 1 & 2 & 3 & 4 & 5 & 6 & 7 \\
\hline hotele & 113 & 2540 & 10801 & 261508 & 10801 & 258679 \\
\hline motele & 9 & 110 & 261 & 3939 & 261 & 3939 \\
\hline pensjonaty & 3 & 384 & 89 & 15775 & 89 & 13201 \\
\hline $\begin{array}{l}\text { inne obiekty } \\
\text { hotelowe }\end{array}$ & 70 & 1030 & 2862 & 54695 & 2715 & 51353 \\
\hline $\begin{array}{l}\text { Razem (obiekty } \\
\text { hotelarskie) }\end{array}$ & 195 & 4064 & 14013 & 335917 & 13866 & 327172 \\
\hline domy wycieczkowe & 5 & 41 & 351 & 3051 & 351 & 2751 \\
\hline schroniska ogółem & 8 & 408 & 350 & 22936 & 311 & 16601 \\
\hline hostele & 10 & 160 & 556 & 10099 & 556 & 9263 \\
\hline $\begin{array}{l}\text { Razem (domy } \\
\text { wycieczkowe, } \\
\text { schroniska } \\
\text { i hostele) }\end{array}$ & 23 & 609 & 1257 & 36086 & 1218 & 28615 \\
\hline
\end{tabular}




\begin{tabular}{|c|c|c|c|c|c|c|}
\hline 1 & 2 & 3 & 4 & 5 & 6 & 7 \\
\hline kempingi & 0 & 157 & 0 & 25298 & 0 & 1497 \\
\hline pola biwakowe & 3 & 167 & 180 & 19497 & 0 & 440 \\
\hline $\begin{array}{l}\text { Razem (kempingi } \\
\text { i pola biwakowe) }\end{array}$ & 3 & 324 & 180 & 44795 & $\mathbf{0}$ & 1937 \\
\hline $\begin{array}{l}\text { ośrodki wypoczyn- } \\
\text { ku sobotnio-nie- } \\
\text { dzielnego } \\
\text { i świątecznego oraz } \\
\text { zespoły domków } \\
\text { turystycznych }\end{array}$ & 12 & 493 & 1239 & 29297 & 213 & 3957 \\
\hline $\begin{array}{l}\text { ośrodki wczasowe } \\
\text { i kolonijne }\end{array}$ & 16 & 1222 & 1580 & 135746 & 282 & 46211 \\
\hline $\begin{array}{l}\text { ośrodki } \\
\text { szkoleniowo- } \\
\text {-wypoczynkowe }\end{array}$ & 19 & 425 & 1620 & 44797 & 1523 & 30175 \\
\hline $\begin{array}{l}\text { domy pracy } \\
\text { twórczej }\end{array}$ & 1 & 32 & 36 & 1581 & 36 & 1375 \\
\hline $\begin{array}{l}\text { zakłady } \\
\text { uzdrowiskowe }\end{array}$ & 1 & 211 & 120 & 38276 & 120 & 37516 \\
\hline $\begin{array}{l}\text { Razem (ośrodki } \\
\text { wypoczynkowe) }\end{array}$ & 49 & 2383 & 4595 & 249697 & 2174 & 119234 \\
\hline pokoje gościnne & 29 & 2083 & 620 & 50402 & 526 & 24277 \\
\hline $\begin{array}{l}\text { kwatery } \\
\text { agroturystyczne }\end{array}$ & 22 & 746 & 459 & 12837 & 246 & 8873 \\
\hline $\begin{array}{l}\text { pozostałe obiekty } \\
\text { niesklasyfikowane }\end{array}$ & 16 & 514 & 1086 & 44223 & 783 & 22491 \\
\hline $\begin{array}{l}\text { Razem (obiekty } \\
\text { zakwaterowania } \\
\text { indywidualnego) }\end{array}$ & 67 & 3343 & 2165 & 107462 & 1555 & 55641 \\
\hline Razem & 337 & 10723 & 22210 & 773957 & 18813 & 532599 \\
\hline
\end{tabular}

Źródło: opracowanie własne za: Turystyka w 2017 roku 2018. 
Tabela 7. Struktura rodzajowa turystycznej bazy noclegowej województwa łódzkiego i Polski w 2017 roku (w \%)

\begin{tabular}{|c|c|c|c|c|c|c|}
\hline \multirow{2}{*}{$\begin{array}{c}\text { Klasyfikacja } \\
\text { turystycznej } \\
\text { bazy noclegowej }\end{array}$} & \multicolumn{2}{|c|}{ Obiekty } & \multicolumn{2}{|c|}{$\begin{array}{c}\text { Miejsca } \\
\text { noclegowe } \\
\text { ogółem }\end{array}$} & \multicolumn{2}{|c|}{$\begin{array}{c}\text { Miejsca } \\
\text { noclegowe } \\
\text { całoroczne }\end{array}$} \\
\hline & $\begin{array}{c}\text { woj. } \\
\text { łódzkie }\end{array}$ & Polska & $\begin{array}{l}\text { woj. } \\
\text { tódzkie }\end{array}$ & Polska & $\begin{array}{c}\text { woj. } \\
\text { łódzkie }\end{array}$ & Polska \\
\hline 1 & 2 & 3 & 4 & 5 & 6 & 7 \\
\hline hotele & 33,5 & 23,7 & 48,6 & 33,8 & 57,4 & 48,6 \\
\hline motele & 2,7 & 1,0 & 1,2 & 0,5 & 1,4 & 0,7 \\
\hline pensjonaty & 0,9 & 3,6 & 0,4 & 2,0 & 0,5 & 2,5 \\
\hline inne obiekty hotelowe & 20,8 & 9,6 & 12,9 & 7,1 & 14,4 & 9,6 \\
\hline $\begin{array}{l}\text { Razem (obiekty } \\
\text { hotelarskie) }\end{array}$ & 57,9 & 37,9 & 63,1 & 43,4 & 73,7 & 61,4 \\
\hline domy wycieczkowe & 1,5 & 0,4 & 1,6 & 0,4 & 1,9 & 0,5 \\
\hline schroniska ogółem & 2,4 & 3,8 & 1,6 & 3,0 & 1,6 & 3,1 \\
\hline hostele & 3,0 & 1,5 & 2,5 & 1,3 & 3,0 & 1,7 \\
\hline $\begin{array}{l}\text { Razem (domy } \\
\text { wycieczkowe, } \\
\text { schroniska i hostele) }\end{array}$ & 6,9 & 5,7 & 5,7 & 4,7 & 6,5 & 5,3 \\
\hline kempingi & 0 & 1,5 & 0 & 3,3 & 0 & 0,3 \\
\hline pola biwakowe & 0,9 & 1,5 & 0,8 & 2,5 & 0 & 0,1 \\
\hline $\begin{array}{l}\text { Razem (kempingi } \\
\text { i pola biwakowe) }\end{array}$ & 0,9 & 3,0 & 0,8 & 5,8 & $\mathbf{0}$ & 0,4 \\
\hline $\begin{array}{l}\text { ośrodki wypoczynku } \\
\text { sobotnio-niedzielnego } \\
\text { i świątecznego oraz } \\
\text { zespoły domków } \\
\text { turystycznych }\end{array}$ & 3,6 & 4,6 & 5,6 & 3,8 & 1,1 & 0,7 \\
\hline $\begin{array}{l}\text { ośrodki wczasowe } \\
\text { i kolonijne }\end{array}$ & 4,7 & 11,4 & 7,1 & 17,5 & 1,5 & 8,7 \\
\hline
\end{tabular}




\begin{tabular}{|l|c|c|c|c|c|c|}
\hline \multicolumn{1}{|c|}{1} & 2 & 3 & 4 & 5 & 6 & 7 \\
\hline $\begin{array}{l}\text { ośrodki szkoleniowo- } \\
\text {-wypoczynkowe }\end{array}$ & 5,6 & 4,0 & 7,3 & 5,8 & 8,1 & 5,7 \\
\hline domy pracy twórczej & 0,3 & 0,3 & 0,2 & 0,2 & 0,2 & 0,3 \\
\hline zakłady uzdrowiskowe & 0,3 & 2,0 & 0,5 & 4,9 & 0,6 & 7,0 \\
\hline $\begin{array}{l}\text { Razem (ośrodki } \\
\text { wypoczynkowe) }\end{array}$ & $\mathbf{1 4 , 5}$ & $\mathbf{2 2 , 3}$ & $\mathbf{2 0 , 7}$ & $\mathbf{3 2 , 2}$ & $\mathbf{1 1 , 5}$ & $\mathbf{2 2 , 4}$ \\
\hline pokoje gościnne & 8,6 & 19,4 & 2,8 & 6,5 & 2,8 & 4,6 \\
\hline $\begin{array}{l}\text { kwatery agrotury- } \\
\text { styczne }\end{array}$ & $\mathbf{6 , 5}$ & 6,9 & 2,0 & 1,7 & 1,3 & 1,7 \\
\hline $\begin{array}{l}\text { pozostałe obiekty } \\
\text { niesklasyfikowane }\end{array}$ & 4,7 & 4,8 & 4,9 & 5,7 & 4,2 & 4,2 \\
\hline $\begin{array}{l}\text { Razem (obiekty } \\
\text { zakwaterowania } \\
\text { indywidualnego) }\end{array}$ & $\mathbf{1 9 , 8}$ & $\mathbf{3 1 , 1}$ & $\mathbf{9 , 7}$ & $\mathbf{1 3 , 9}$ & $\mathbf{8 , 3}$ & $\mathbf{1 0 , 5}$ \\
\hline \begin{tabular}{l} 
Ogółem \\
\hline
\end{tabular} & $\mathbf{1 0 0 , 0}$ & 100,0 & 100,0 & 100,0 & 100,0 & 100,0 \\
\hline
\end{tabular}

Źródło: obliczenie za: Turystyka w 2017 roku 2018.

Do 2005 roku zarówno w całym kraju, jak i województwie łódzkim liczba obiektów oraz ich miejsc noclegowych ogółem zmniejszyła się blisko o jedną czwartą w stosunku do stanu z 1990 roku. Dopiero po 2005 roku nastąpiło systematyczne odtwarzanie potencjału turystycznej bazy noclegowej sprzed 15 lat. Ostatecznie w 2015 roku odbudowano stan zasobów turystycznej bazy noclegowej zarówno w kraju, jak i województwie łódzkim, a liczba obiektów i ich miejsc noclegowych ogółem wyraźnie przekroczyła poziom z 1990 roku. Cechą charakterystyczną zmian zachodzących w Polsce po tymże roku w turystycznej bazie noclegowej był systematyczny wzrost liczby miejsc noclegowych całorocznych. Przed 1990 rokiem wiele obiektów, mimo że niektóre z nich przygotowane były do eksploatacji całorocznej, wykorzystywano tylko sezonowo. Po ich prywatyzacji i niezbędnej adaptacji stworzono możliwości korzystania z nich przez cały rok. Uruchomiono też szereg nowych hoteli, które są obiektami całorocznymi. Dynamika wzrostu liczby miejsc noclegowych całorocznych w województwie lódzkim, zwłaszcza po 2005 roku była wyższa (2,8-krotna), niż przeciętnie w całym kraju (2,5-krotna). W rezultacie czego w 2017 roku udział miejsc noclegowych całorocznych w całkowitej pojemności bazy noclegowej województwa osiągnął 
wielkość rzędu 85\% (w 1990 roku wynosił tylko 35,7\%) i był wyższy niż przeciętnie w kraju - 68,8\% (w 1990 roku zaledwie 28,7\%). Dokumentują to dane zestawione w tabelach 6. i 7. oraz na rysunku 3.

Ogólnie rzecz ujmując, wzrost liczby obiektów turystycznej bazy noclegowej i jej pojemności w województwie łódzkim w latach 1990-2017 spowodował również niewielki wzrost jego udziału w potencjale krajowym. W owym okresie udział województwa w liczbie obiektów wzrósł do 3,2\%, miejsc noclegowych ogółem do blisko 3\%, a całorocznych do 3,5\%. Przeciętna wielkość pojemności pojedynczego obiektu noclegowego w województwie, mimo że w owym czasie ulegała sporym zmianom, była pod koniec niemal identyczna, jak na początku i w przybliżeniu osiągnęła 66 miejsc noclegowych. W tym zakresie trend ogólnokrajowy, pomimo okresowych wahań, był spadkowy, przeciętna pojemność pojedynczego obiektu noclegowego zmalała z 83,3 do 72,5 miejsca noclegowego.
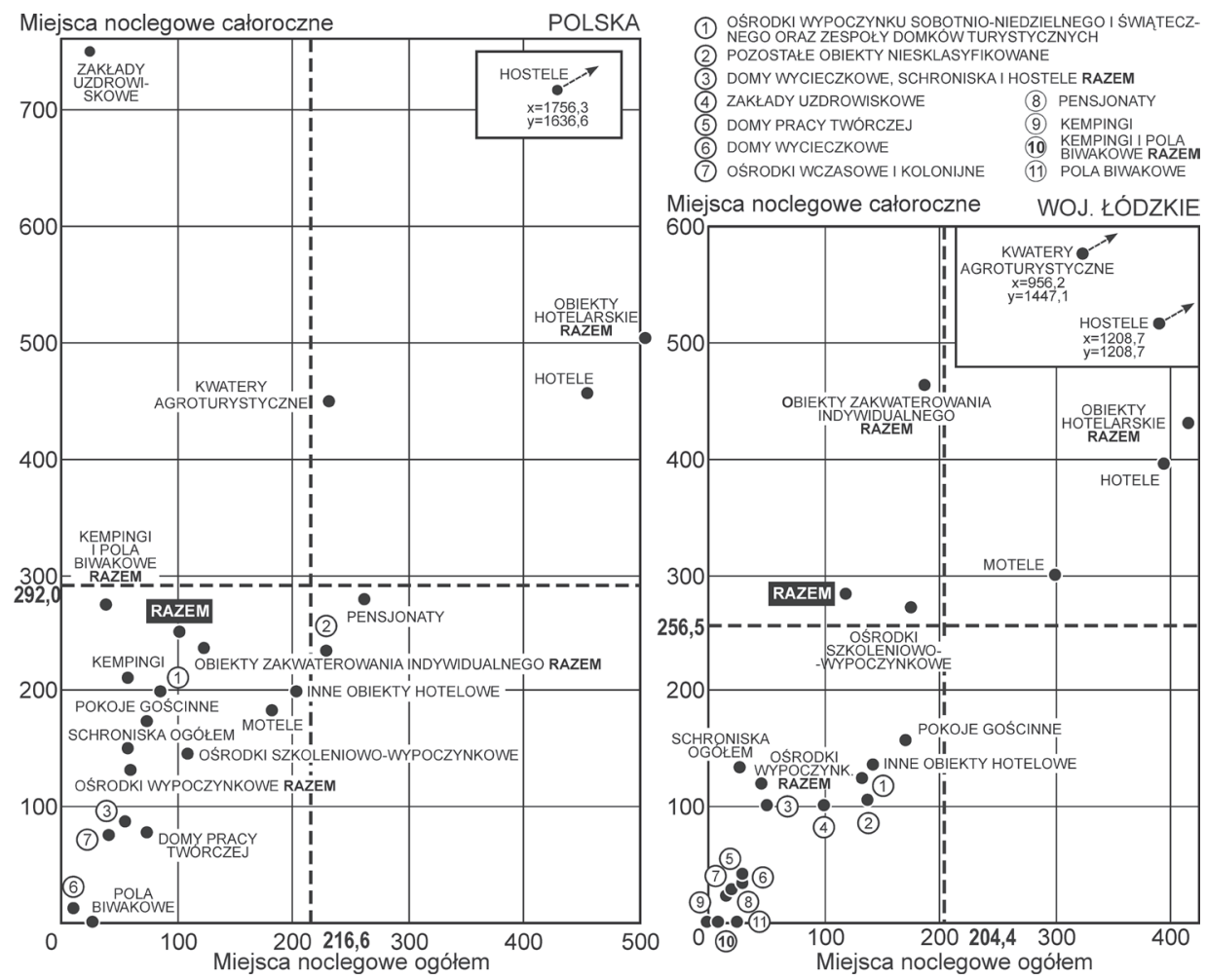

Rysunek 3. Dynamika wzrostu obiektów bazy noclegowej poszczególnych rodzajów w Polsce i województwie lódzkim w latach 1990-2017

Źródło: opracowanie własne za: Turystyka w 1990 roku 1991 i kolejne roczniki do Turystyka w 1917 roku 2018 
Dynamikę zmian w latach 1990-2017 w poszczególnych rodzajach obiektów turystycznej bazy noclegowej, zarówno w kraju, jak i województwie lódzkim, charakteryzowały odmienne trendy (rys. 3). Baza noclegowa obsługująca turystykę socjalną wykazywała trend spadkowy, natomiast obsługująca turystykę komercyjną wzrostowy (tab. 8). Liczba obiektów hotelarskich w owym okresie w województwie wzrosła sześciokrotnie, ale ich pojemność tylko czterokrotnie. W kraju dynamika wzrostu tej grupy obiektów była bardziej zrównoważona, mniej więcej pięciokrotna. Pokazuje to, że w województwie łódzkim uruchamiano więcej obiektów hotelarskich, ale o mniejszej pojemności, niż w całym kraju. Drugą grupą turystycznych obiektów noclegowych w województwie wykazującą wyraźny wzrost były obiekty zakwaterowania indywidualnego $\mathrm{z}$ dynamiką wzrostu znacznie wyższą niż ogólnie w Polsce. Znaczna dynamika dotyczyła też rejestrowanych od 2009 roku przez GUS hosteli, jednak w województwie łódzkim była ona dużo niższa niż w kraju. Natomiast dla pozostałych rodzajów turystycznych obiektów noclegowych w województwie charakterystyczne były trendy spadkowe, wyraźnie silniejsze niż ogólnie w Polsce.

Tabela 8. Dynamika wzrostu potencjału bazy noclegowej w województwie łódzkim na tle Polski według jej rodzajów w latach 1990-2017 (1990 rok = 100)

\begin{tabular}{|c|c|c|c|c|c|c|}
\hline \multirow{2}{*}{$\begin{array}{l}\text { Klasyfikacja tury- } \\
\text { stycznej } \\
\text { bazy noclegowej }\end{array}$} & \multicolumn{2}{|c|}{ Obiekty } & \multicolumn{2}{|c|}{$\begin{array}{c}\text { Miejsca } \\
\text { noclegowe } \\
\text { ogółem }\end{array}$} & \multicolumn{2}{|c|}{$\begin{array}{c}\text { Miejsca } \\
\text { noclegowe } \\
\text { całoroczne }\end{array}$} \\
\hline & $\begin{array}{l}\text { woj. } \\
\text { fódzkie }\end{array}$ & Polska & $\begin{array}{l}\text { woj. } \\
\text { tódzkie }\end{array}$ & Polska & $\begin{array}{l}\text { woj. } \\
\text { lódzkie }\end{array}$ & Polska \\
\hline 1 & 2 & 3 & 4 & 5 & 6 & 7 \\
\hline hotele & 418,5 & 509,0 & 394,5 & 455,6 & 394,5 & 454,8 \\
\hline motele & 450,0 & 297,3 & 300,0 & 182,9 & 300,0 & 182,9 \\
\hline pensjonaty & 100,0 & 238,5 & 16,2 & 261,9 & 22,3 & 279,0 \\
\hline inne obiekty hotelowe & 112,9 & 177,6 & 144,0 & 203,9 & 136,6 & 199,6 \\
\hline $\begin{array}{l}\text { Razem (obiekty } \\
\text { hotelarskie) }\end{array}$ & 609,4 & 583,1 & 415,3 & 512,2 & 430,1 & 513,1 \\
\hline domy wycieczkowe & 22,7 & 11,2 & 29,5 & 12,3 & 35,7 & 12,5 \\
\hline schroniska ogółem & 20,0 & 40,0 & 27,0 & 57,9 & 133,5 & 148,9 \\
\hline hostele & 333,3 & 842,1 & 1208,7 & 1756,3 & 1208,7 & 1636,6 \\
\hline
\end{tabular}


Tabela 8 (cd.)

\begin{tabular}{|l|r|r|r|r|r|r|}
\hline \multicolumn{1}{|c|}{1} & \multicolumn{1}{|c|}{2} & \multicolumn{1}{c|}{4} & \multicolumn{1}{c|}{5} & \multicolumn{1}{c|}{6} & \multicolumn{1}{c|}{7} \\
\hline $\begin{array}{l}\text { Razem (domy } \\
\text { wycieczkowe, } \\
\text { schroniska i hostele) }\end{array}$ & $\mathbf{3 7 , 1}$ & $\mathbf{4 4 , 0}$ & $\mathbf{5 0 , 5}$ & $\mathbf{5 6 , 0}$ & $\mathbf{1 0 0 , 2}$ & $\mathbf{8 6 , 2}$ \\
\hline kempingi & 0 & 78,9 & 0 & 58,8 & 0 & 211,1 \\
\hline pola biwakowe & 30,0 & 42,8 & 25,0 & 27,3 & 0 & 0 \\
\hline $\begin{array}{l}\text { Razem (kempingi i } \\
\text { pola biwakowe) }\end{array}$ & $\mathbf{1 5 , 0}$ & $\mathbf{5 5 , 0}$ & $\mathbf{9 , 2}$ & $\mathbf{3 9 , 1}$ & $\mathbf{0}$ & $\mathbf{2 7 3 , 2}$ \\
\hline $\begin{array}{l}\text { ośrodki wypoczynku } \\
\text { sobotnio-niedziel- } \\
\text { nego i świątecznego } \\
\text { oraz zespoly domków } \\
\text { turystycznych }\end{array}$ & 75,0 & 95,0 & 133,5 & 86,8 & 123,8 & 197,5 \\
\hline $\begin{array}{l}\text { ośrodki wczasowe } \\
\text { i kolonijne }\end{array}$ & 12,8 & 28,8 & 20,6 & 42,6 & 28,3 & 73,7 \\
\hline $\begin{array}{l}\text { ośrodki szkoleniowo- } \\
\text {-wypoczynkowe }\end{array}$ & 158,3 & 100,7 & 175,5 & 111,2 & 271,0 & 145,7 \\
\hline domy pracy twórczej & 50,0 & 62,7 & 29,5 & 75,4 & 39,0 & 77,5 \\
\hline zakłady uzdrowiskowe & 100,0 & 202,9 & 100 & 212,9 & 100 & 750,2 \\
\hline $\begin{array}{l}\text { Razem (ośrodki } \\
\text { wypoczynkowe) }\end{array}$ & $\mathbf{3 1 , 6}$ & $\mathbf{3 7 , 6}$ & $\mathbf{4 7 , 7}$ & $\mathbf{6 0 , 5}$ & $\mathbf{1 2 0 , 0}$ & $\mathbf{1 2 9 , 7}$ \\
\hline $\begin{array}{l}\text { pokoje gościnne } \\
\text { kwatery agroturystyczne }\end{array}$ & 314,3 & 122,7 & 956,2 & 233,0 & 1447,1 & 449,0 \\
\hline $\begin{array}{l}\text { pozostałe obiekty } \\
\text { niesklasyfikowane }\end{array}$ & 400,0 & 276,3 & 137,6 & 229,6 & 106,2 & 234,2 \\
\hline $\begin{array}{l}\text { Razem (obiekty } \\
\text { zakwaterowania } \\
\text { indywidualnego) }\end{array}$ & $\mathbf{4 6 6 , 7}$ & $\mathbf{3 6 7 , 4}$ & $\mathbf{1 8 8 , 4}$ & $\mathbf{1 2 4 , 9}$ & $\mathbf{4 6 2 , 8}$ & $\mathbf{2 3 6 , 0}$ \\
\hline $\begin{array}{l}\text { Razem (wszystkie } \\
\text { obiekty turystycznej } \\
\text { bazy noclegowej) }\end{array}$ & $\mathbf{1 1 8 , 7}$ & $\mathbf{1 1 9 , 2}$ & $\mathbf{1 1 9 , 3}$ & $\mathbf{1 0 4 , 2}$ & $\mathbf{2 8 3 , 0}$ & $\mathbf{2 4 9 , 9}$ \\
\hline
\end{tabular}

Źródło: opracowanie własne za: Turystyka w 1990 roku 1991 i kolejne roczniki do Turystyka w 19172018. 


\begin{tabular}{|c|c|c|c|c|c|c|c|c|c|c|c|c|c|c|}
\hline 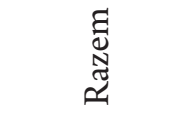 & $\Lambda$ & 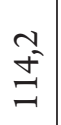 & $\begin{array}{l}\infty \\
\infty \\
\infty\end{array}$ & $\begin{array}{l}\vec{n} \\
i n \\
m\end{array}$ & $\stackrel{n}{n}$ & $\frac{n}{n}$ & $\begin{array}{l}\circ \\
\stackrel{0}{0}\end{array}$ & $\stackrel{0}{\infty}$ & $\begin{array}{c}0 \\
\aleph^{-}\end{array}$ & $\begin{array}{l}0 \\
\text { ò } \\
+\end{array}$ & $\begin{array}{l} \pm \\
\pm \\
\Xi\end{array}$ & $\widetilde{f}$ & $\hat{0}$ & à \\
\hline 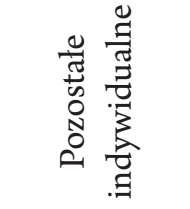 & 6 & 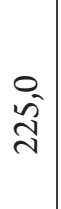 & $\begin{array}{l}\tilde{0} \\
\text { శై }\end{array}$ & 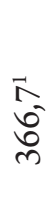 & 0 & 0 & $\begin{array}{l}\infty \\
\infty^{\infty} \\
\sim\end{array}$ & $\begin{array}{c}2 \\
\sigma^{\prime} \\
+\end{array}$ & 0 & $\stackrel{\mathscr{Z}}{\exists}$ & $\begin{array}{l}\sqrt{1} \\
\mathbb{0}^{-} \\
m^{2}\end{array}$ & $\stackrel{n}{n}$ & $\frac{\sqrt{0}}{6}$ & 6 \\
\hline 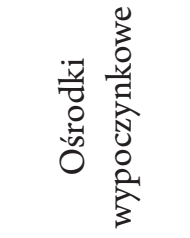 & $n$ & 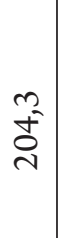 & $\stackrel{ }{-}$ & 0 & $\begin{array}{l}0 \\
\infty 0^{-} \\
0\end{array}$ & 0 & $\begin{array}{l}0 \\
\infty \\
+\end{array}$ & $\hat{\hat{N}}$ & 0 & ๙̃ & $\underset{n}{ \pm}$ & $\stackrel{\widetilde{T}}{\stackrel{f}{f}}$ & $\begin{array}{l}0 \\
\infty \\
\infty\end{array}$ & $\begin{array}{l}0 \\
n \\
m\end{array}$ \\
\hline 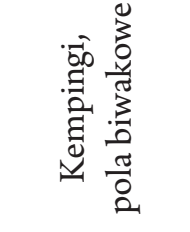 & $\nabla$ & $\sigma$ & 0 & 0 & 0 & 0 & $\sigma$ & $\sigma$ & $\sigma$ & 0 & 0 & $\sigma$ & $\infty^{2}$ & 0 \\
\hline 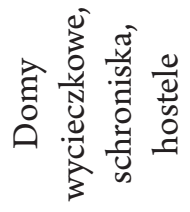 & $m$ & $\sigma$ & $\sigma$ & $\rtimes$ & 0 & 0 & $\begin{array}{l}0 \\
\stackrel{\sim}{\sim}\end{array}$ & $\sigma$ & $\sigma$ & 0 & $\sigma$ & $\sigma$ & $\sigma$ & $\stackrel{+}{\mathrm{N}}$ \\
\hline 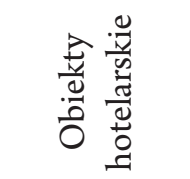 & $N$ & $\begin{array}{c}0 \\
\overline{0} \\
\sim\end{array}$ & $\stackrel{2}{N}$ & $\stackrel{0}{\stackrel{0}{*}}$ & $\underset{m}{\mathbb{f}}$ & $\begin{array}{l}0 \\
\tilde{N} \\
0 \\
\text { n }\end{array}$ & 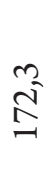 & $\begin{array}{l}+ \\
\sigma^{-} \\
n \\
n\end{array}$ & స్ & $\begin{array}{l}\infty \\
\tilde{n} \\
0 \\
0\end{array}$ & $\hat{\sigma}^{2}$ & $\begin{array}{l}2 \\
\delta^{2} \\
e^{2}\end{array}$ & 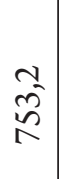 & $\overrightarrow{\tilde{\sigma}^{\circ}}$ \\
\hline $\begin{array}{l}. \frac{\pi}{3} \\
\text {. } \\
0 \\
0\end{array}$ & $\neg$ & 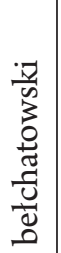 & 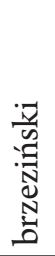 & 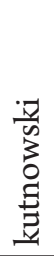 & $\frac{i \pi}{\tilde{D}}$ & 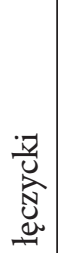 & 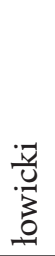 & 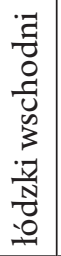 & 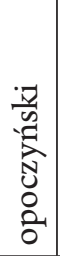 & 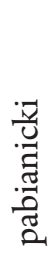 & 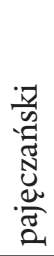 & 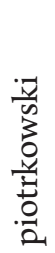 & 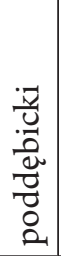 & 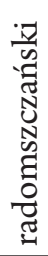 \\
\hline
\end{tabular}




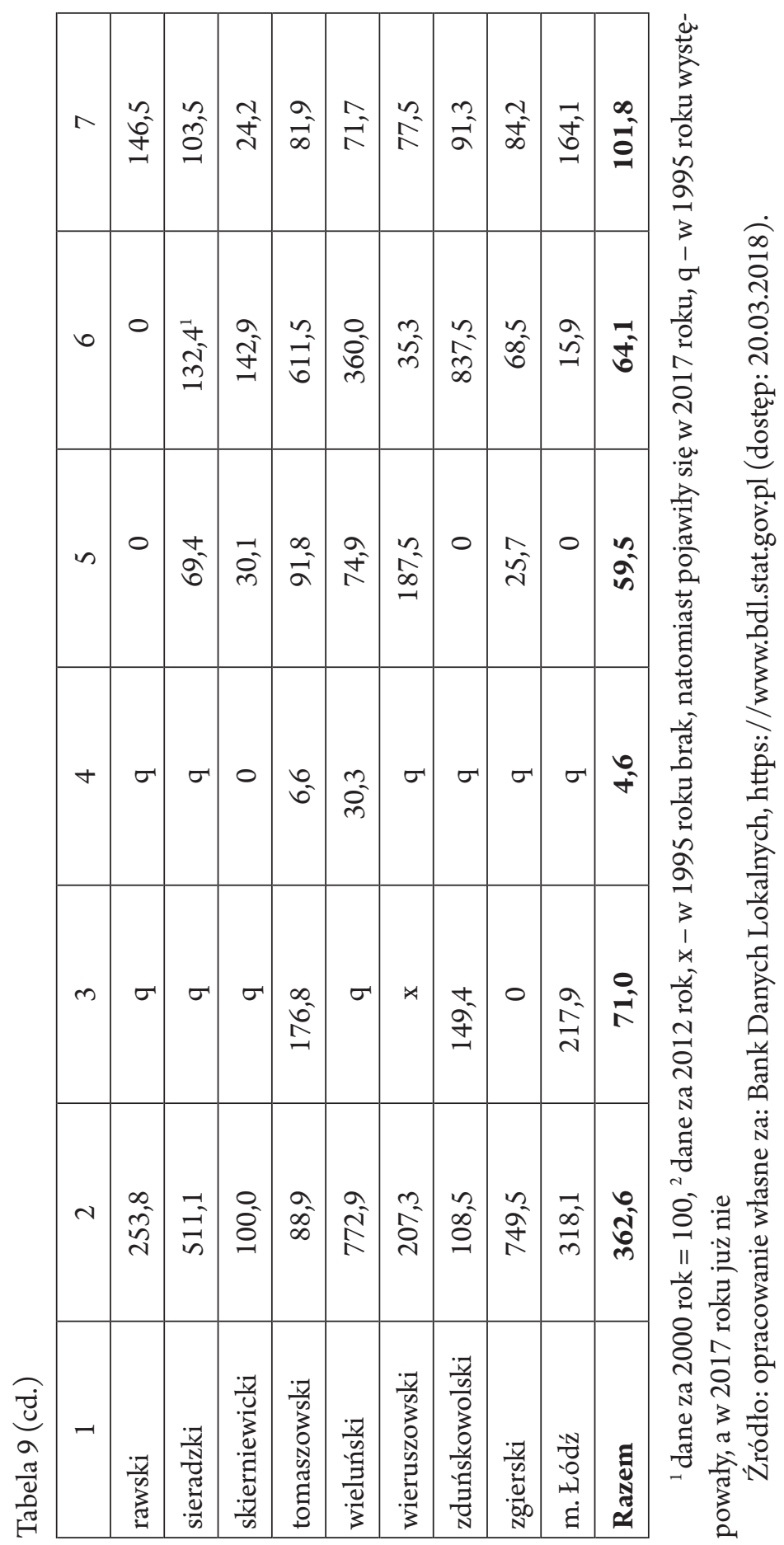


Wielkość turystycznej bazy noclegowej województwa łódzkiego w latach 1995-2017, w porównaniu z pozostałymi 15 regionami, lokowała je na 10-13 pozycji w kraju. Pod tym względem wyprzedzało ono jedynie takie województwa jak: lubelskie, lubuskie, podlaskie, świętokrzyskie i opolskie. $\mathrm{W}$ porównaniu z najbardziej zasobnymi w turystyczną bazę noclegową województwami, region lódzki miał niemal pięciokrotnie mniejszą liczbę turystycznych obiektów i miejsc noclegowych.

W latach 1995-2017 dynamika wzrostu pojemności turystycznej bazy noclegowej w województwie łódzkim była wyraźnie zróżnicowana przestrzennie (rys. 2). Jedynie w blisko połowie powiatów odnotowano wzrost liczby miejsc noclegowych ogółem. Natomiast w pozostałych dość duży spadek. Inaczej wyglądało zróżnicowanie przestrzenne dynamiki wzrostu całorocznych miejsc noclegowych. W większości powiatów (z wyjątkiem skierniewickiego i Skierniewic) nastąpił wzrost ich liczby (tab. 9 i rys. 4). Wielkość i zróżnicowanie przestrzenne dynamiki wzrostu liczby całorocznych miejsc noclegowych było czynnikiem kształtującym tempo wzrostu pojemności obiektów hotelarskich, w tym głównie hoteli. Najwyższą dynamikę w tym względzie odnotowano $\mathrm{w}$ powiatach: pabianickim, wieluńskim, łódzkim wschodnim, poddębickim, zgierskim, opoczyńskim, sieradzkim, radomszczańskim i kutnowskim (4,5-10-krotny przyrost). Spadek pojemności takich obiektów odnotowano tylko w powiecie brzezińskim i tomaszowskim. W pozostałych powiatach i Łodzi dynamika wzrostu kształtowała się na przeciętnym poziomie (1-3,5-krotny przyrost). Większe zróżnicowanie przestrzenne miała ona w odniesieniu do obiektów zakwaterowania indywidualnego. Obok kilku powiatów (m.in. zduńskowolskiego, poddębickiego, tomaszowskiego, łódzkiego wschodniego), odnotowujących wysoką dynamikę wzrostu pojemności takich obiektów, pojawiło się szereg innych ze znacznym jego spadkiem. W pozostałych rodzajach obiektów turystycznej bazy noclegowej wystąpiła tendencja spadkowa ich pojemności w większości powiatów. W grupie ośrodków wypoczynkowych tylko w powiecie bełchatowskim i wieruszowskim odnotowano wzrost ich pojemności, natomiast w pozostałych wyraźny spadek. Jeśli chodzi o domy wycieczkowe, schroniska i hostele oraz kempingi i pola biwakowe - $w$ wielu powiatach zlikwidowano je. Jedynie pojemność hosteli w Łodzi i powiecie tomaszowskim oraz schronisk w zduńskowolskim charakteryzowała się dodatnią dynamiką wzrostu. 


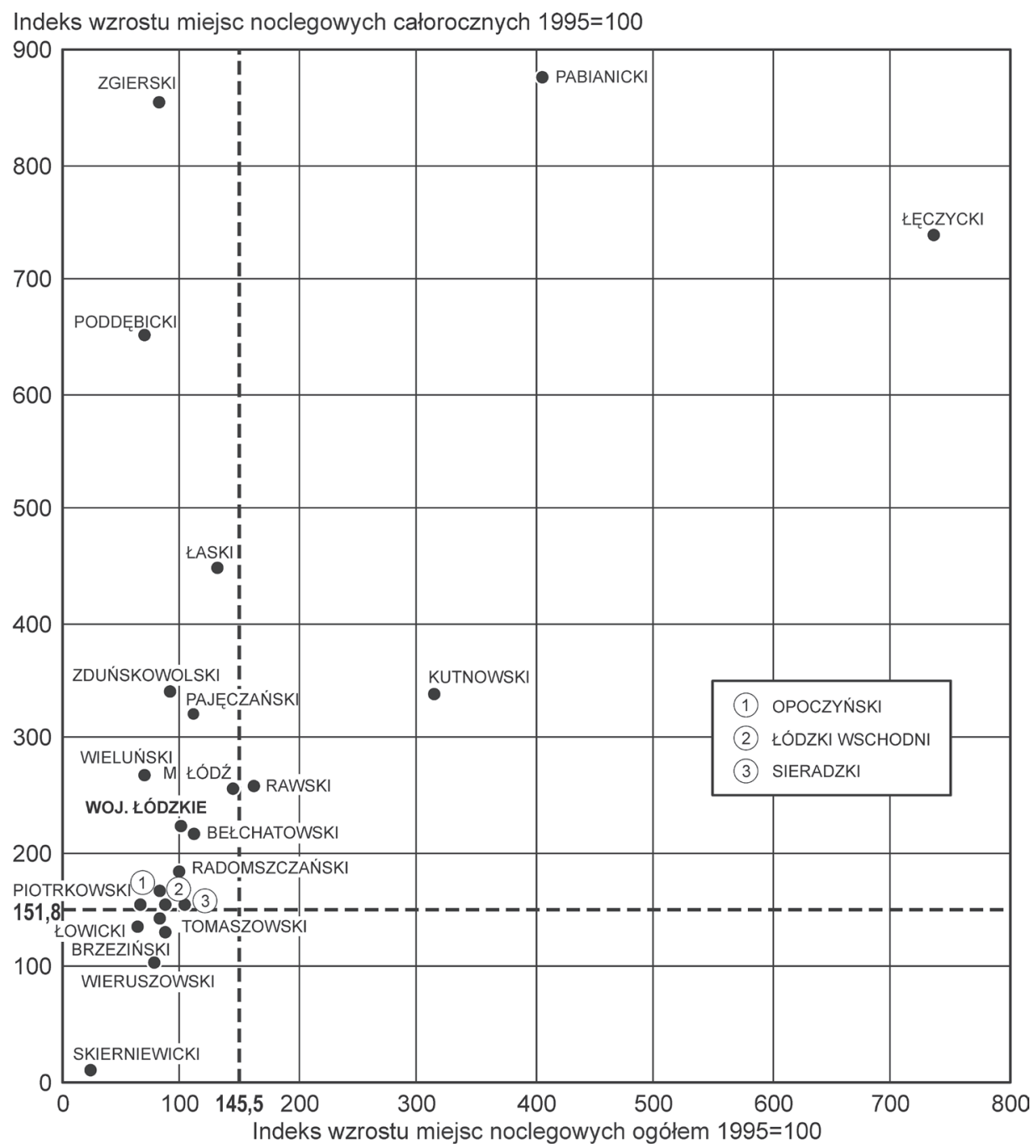

Rysunek 4. Indeks wzrostu liczby miejsc noclegowych w powiatach regionu lódzkiego w latach 1995-2017

Źródło: opracowanie własne za: Bank Danych Lokalnych, https://www.bdl.stat.gov.pl (dostęp: 20.03.2018)

Przedstawione zróżnicowanie przestrzenne dynamiki wzrostu pojemności poszczególnych rodzajów obiektów noclegowych spowodowało określone zmiany w strukturze turystycznej bazy noclegowej w województwie łódzkim w 2017 roku. 
Tabela 10. Wartości wskaźników koncentracji pojemności bazy noclegowej województwa łódzkiego w latach 1995 i 2017

\begin{tabular}{|l|c|c|}
\hline \multirow{2}{*}{\multicolumn{1}{|c|}{ Rodzaj bazy noclegowej }} & \multicolumn{2}{c|}{ Wskaźnik koncentracji $\eta$} \\
\cline { 2 - 3 } & $\mathbf{1 9 9 5}$ & $\mathbf{2 0 1 7}$ \\
\hline Miejsca noclegowe ogółem & 0,542 & 0,562 \\
\hline Miejsca noclegowe całoroczne & 0,627 & 0,602 \\
\hline Obiekty hotelarskie & 0,811 & 0,627 \\
\hline Hotele & 0,862 & 0,69 \\
\hline Domy wycieczkowe, schroniska, hostele & 0,609 & 0,923 \\
\hline Ośrodki wypoczynkowe & 0,567 & 0,563 \\
\hline Kempingi i pola biwakowe & 0,62 & 0,888 \\
\hline Obiekty zakwaterowania indywidualnego & 0,826 & 0,575 \\
\hline
\end{tabular}

Źródło: opracowanie własne za: Bank Danych Lokalnych, https://www.bdl.stat. gov.pl (dostęp: 20.03.2018).

Dotyczyły one głównie domów wycieczkowych, schronisk i hosteli, które w wielu powiatach zostały zlikwidowane lub ograniczyły liczbę miejsc noclegowych. Wzrost w ostatnich latach (po 2009 roku) liczby hosteli, który dotyczył głównie Łodzi, nie zrekompensował ubytku odnotowanego w tej grupie obiektów noclegowych. W 1995 roku 16 powiatów miało takie obiekty, natomiast w 2017 roku zaledwie siedem. Stąd też wskaźnik koncentracji wzrósł z 0,609 do 0,923 (tab. 10). Podobny trend miał miejsce w wypadku kempingów i pól biwakowych, które systematycznie likwidowano. W 1995 roku występowały w 14 powiatach, a w 2017 roku tylko w trzech. Wskaźnik koncentracji wzrósł z 0,62 do 0,89. Z kolei w grupie ośrodków wypoczynkowych pomimo spadku liczby miejsc noclegowych podobna lokalizacja utrzymała się do 2017 roku, o czym świadczy wartość wskaźnika koncentracji, który odpowiednio wynosił 0,567 i 0,563. Natomiast odmienna tendencja wystąpiła w odniesieniu do obiektów hotelarskich, a zwłaszcza hoteli i obiektów zakwaterowania indywidualnego. W dużym stopniu rozpowszechniły się, stąd też zmalała wartość ich wskaźników koncentracji. W wypadku obiektów zakwaterowania indywidualnego, mimo że zmalała w nich liczba miejsc noclegowych, głównie na skutek ich dużego ubytku w Łodzi, to umocniły one swoją pozycję w 17 powiatach, gdzie odnotowano ich obecność w 2017 roku. Wskaźnik koncentracji zmalał z 0,826 do 0,575. Z kolei obiekty hotelarskie, które jeszcze w 1995 roku nie były obecne w ośmiu powiatach, w 2017 roku działały już 
we wszystkich (przy 3,6-krotnym wzroście ich pojemności w latach 1995-2017). W rezultacie ich wskaźnik koncentracji zmalał z 0,811 do 0,627. W obrębie tej grupy obiektów dominowaty hotele, stanowiąc nieco powyżej trzech czwartych ich pojemności. O ile w 1995 roku hotele nie występowaty w 11 powiatach, to w 2017 roku - tylko w dwóch. Wskaźnik koncentracji zmniejszył się z 0,86 do 0,69. W 1995 roku w Łodzi skupione było blisko dwie trzecie liczby miejsc noclegowych w hotelach w województwie, natomiast w 2017 roku udział miasta zmalał do mniej niż połowy. Szybszy wzrost liczby obiektów i miejsc noclegowych w hotelach obserwowany poza Łodzią miał miejsce na jej bezpośrednim zapleczu oraz w większych miastach województwa, m.in. Piotrkowie Trybunalskim, Bełchatowie, Kutnie.

Po 1990 roku ilustracją wysokiej dynamiki rozwoju komercyjnej bazy noclegowej jest głównie liczba i pojemność hoteli, która w latach 1990-2017 wzrosła w Polsce pięciokrotnie. W województwie łódzkim, mimo podobnego jak w całym kraju charakteru wzrostu liczby hoteli, jego tempo było wyraźnie niższe. W rezultacie $\mathrm{w}$ województwie lódzkim przyrost liczby i pojemności hoteli był czterokrotny. Struktura hoteli w regionie pod względem kategorii znacząco różniła się od ogólnokrajowej. W województwie łódzkim nie było w ogóle hoteli pięciogwiazdkowych. Z kolei czterogwiazdkowe, które działały przed 1990 rokiem, na początku lat 90 . utracily swój status. Hotele czterogwiazdkowe ponownie pojawiły się w województwie lódzkim dopiero w 2006 roku. W latach 90. ubiegłego wieku w strukturze hotelowej województwa dominowały hotele niższych (dwu-i jednogwiazdkowe) i średnich (trzygwiazdkowe) kategorii.Jeszcze w 2000 roku przewagę nad trzygwiazdkowymi (33,8\% ogółu miejsc hotelowych w województwie) miały hotele dwugwiazdkowe (38,3\%). Te dwie kategorie hoteli uzupelnione były przez hotele jednogwiazdkowe $(27,9 \%)$ będące obiektami małych rozmiarów i dysponujące przeciętnie niewielką liczbą miejsc noclegowych. W 2017 roku sytuacja sektora hotelowego województwa łódzkiego była już inna. Region miał 12 hoteli czterogwiazdkowych z 3,2 tys. miejscami noclegowymi, co stanowiło $27,3 \%$ pojemności całego jego sektora hotelowego. Dominującą pozycję odzyskały hotele trzygwiazdkowe, których liczba (57) wzrosła pięciokrotnie, a pojemność blisko czterokrotnie. W rezultacie ich udział osiągnął $42,9 \%$ pojemności całego sektora hotelowego w województwie. Mimo że odnotowano również wzrost liczby (27) i pojemności (ok. 2,5 tys. miejsc noclegowych) hoteli dwugwiazdkowych, to ich udział zmniejszył się do $21,5 \%$. W 2017 roku marginalny udział $(8,2 \%)$ w liczbie i pojemności sektora hotelowego w regionie miały hotele jednogwiazdkowe i oczekujące na kategoryzację, których było 17 , ale z niecałym tysiącem miejsc noclegowych. Struktura sektora hotelowego pod względem kategorii (pojemność hoteli od cztero- do jednogwiazdkowych) w województwie łódzkim w 2017 roku odzwierciedlała zmiany, jakie nastąpiły w tym zakresie w całym kraju (tab. 11). 
Potencjał i wykorzystanie turystycznej bazy noclegowej...

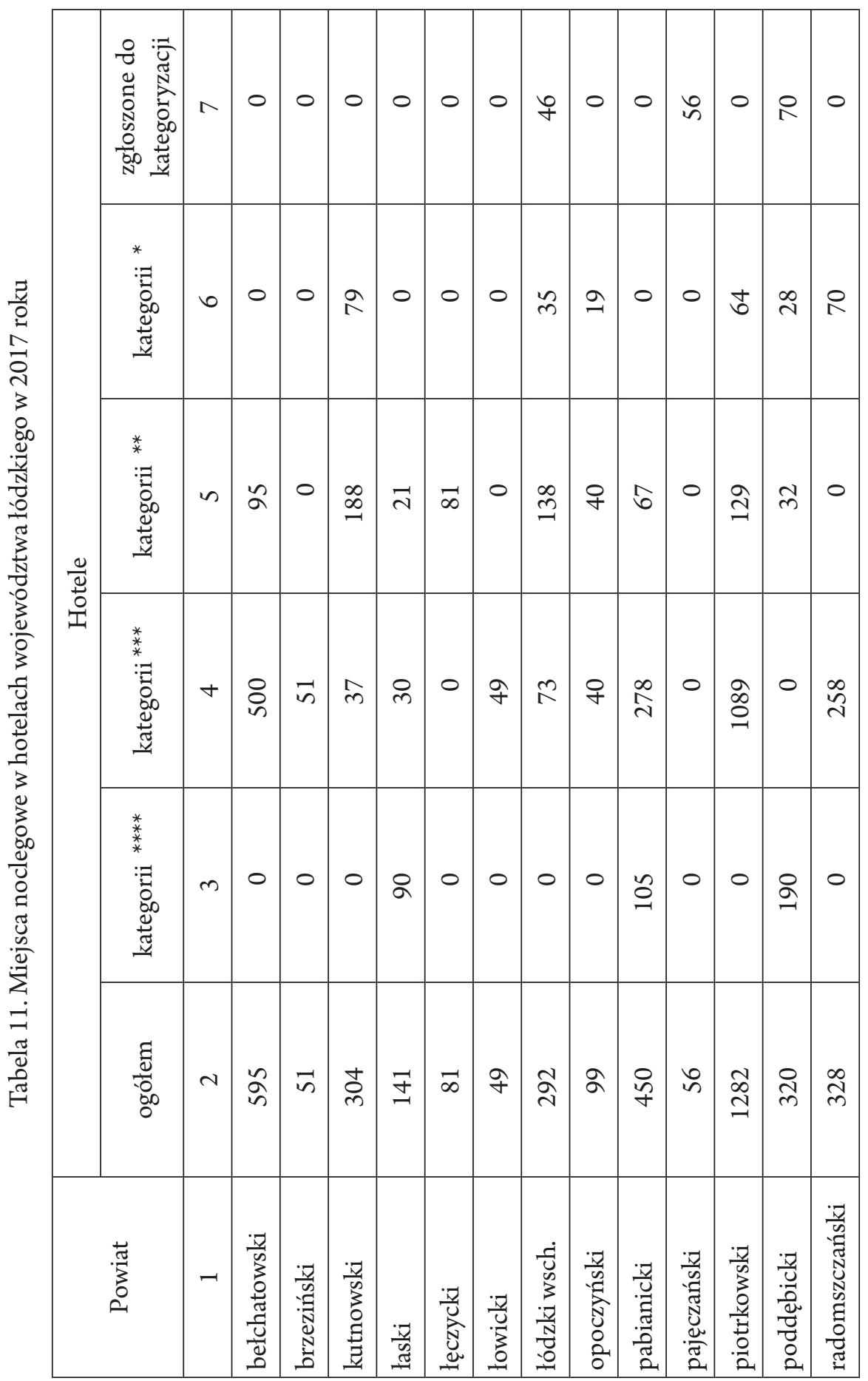




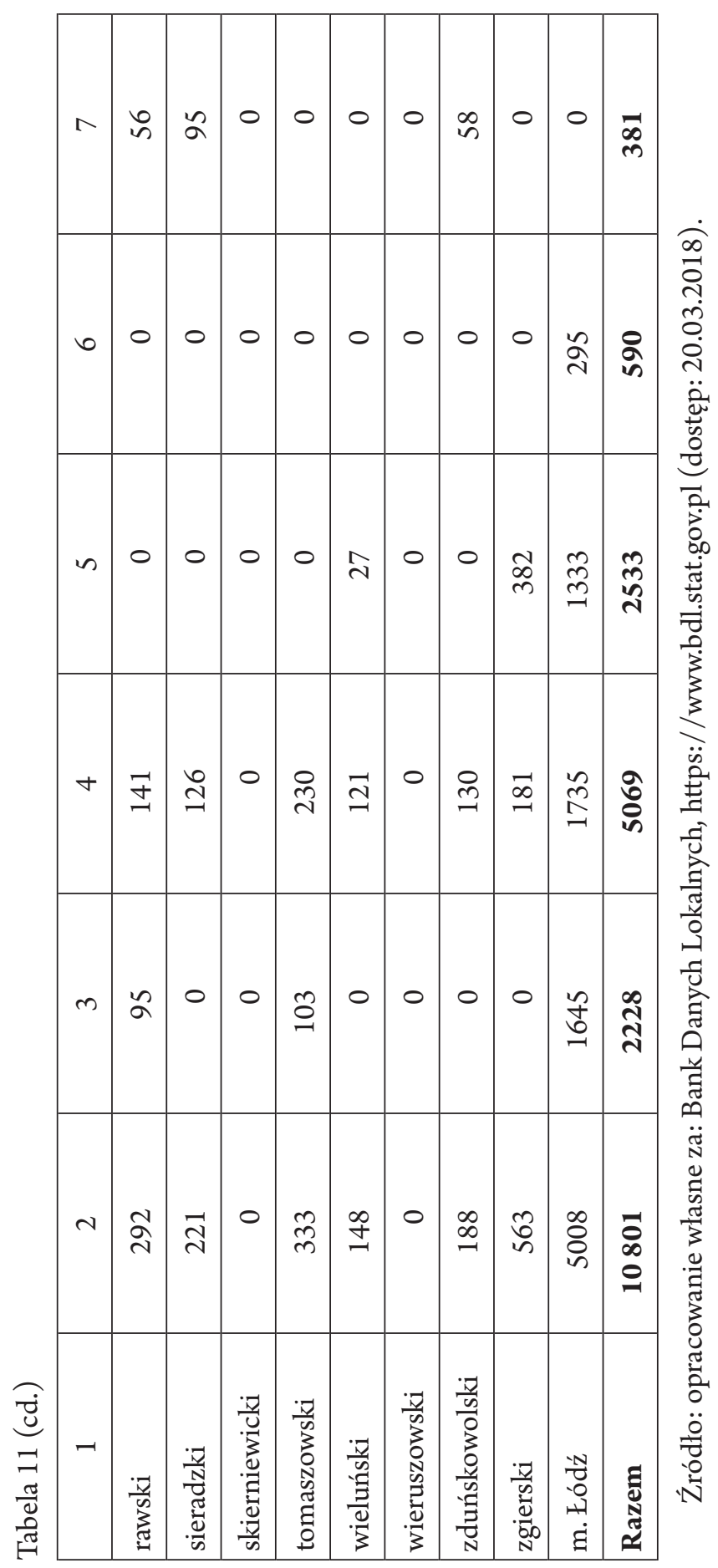


W 2017 roku Łódź miała najwięcej hoteli i znajdujących się w nich miejsc noclegowych w województwie lódzkim. Dotyczyło to zwłaszcza hoteli wyższych kategorii. Połowa hoteli czterogwiazdkowych zlokalizowana była w Łodzi. Skoncentrowane było w nich blisko trzy czwarte miejsc noclegowych $\mathrm{w}$ tej kategorii hoteli $\mathrm{w}$ regionie. Były to hotele duże, liczące średnio 275 miejsc w obiekcie. Hotele czterogwiazdkowe zlokalizowane poza Łodzią (dwa w powiecie poddębickim i po jednym w powiatach laskim, pabianickim, rawski i tomaszowskim) skupiały pozostałą jedną czwartą miejsc noclegowych i były znacznie mniejszych rozmiarów, średnio licząc 100 miejsc. Hotele trzygwiazdkowe były najbardziej rozpowszechnione w województwie. Łódź miała jedną czwartą tych obiektów i jedną trzecią ich pojemności. Pozostałe trzy czwarte hoteli trzygwiazdkowych i dwie trzecie ich pojemności zlokalizowane było w 15 powiatach. Najwięcej w Piotrkowie Trybunalskim (cztery), powiecie piotrkowskim (sześć) oraz bełchatowskim, pabianickim i zgierskim (po cztery). Hotele trzygwiazdkowe zlokalizowane w Łodzi były przeciętnie większe (średnio 124 miejsca) niż znajdujące się poza jej granicami (średnio 77,5 miejsca). Udział Łodzi w potencjale hoteli ekonomicznych (dwui jednogwiazdkowe) był nadal wysoki (odpowiednio 56,2\% i 50\% pojemności w kategorii hoteli). Natomiast ich rozpowszechnienie w województwie już było rzadsze. Hoteli dwugwiazdkowych nie miało w ogóle dziesięć, a jednogwiazdkowych 16 powiatów. Łódzkie hotele dwu-i jednogwiazdkowe były przeciętnie ponad dwukrotnie większe (średnio 148 miejsc) od zlokalizowanych poza nią (dwugwiazdkowe średnio 66,7 miejsca, jednogwiazdkowe średnio 42 miejsca).

\subsubsection{Podsumowanie}

Rozwój profesjonalnej bazy noclegowej w regionie łódzkim nastąpił po II wojnie światowej. Do 1990 roku odnosił się do obiektów noclegowych obsługujących turystykę socjalną w okresie letnim. Konieczność zaspokojenia dużych potrzeb wypoczynkowych mieszkańców regionu spowodowała z jednej strony powstawanie w szybkim tempie nowych ośrodków wypoczynkowych dostosowanych do użytkowania w sezonie letnim, a $\mathrm{z}$ drugiej wykorzystanie obiektów edukacyjnych i innych wolnych (nieużytkowanych) podczas wakacji na cele turystyczno-wypoczynkowe, a także prywatnych zasobów mieszkaniowych (tzw. obiektów zakwaterowania indywidualnego) na cele letniskowe. W szczytowej fazie rozwoju tego typu bazy noclegowej województwo lódzkie w ówczesnych granicach administracyjnych dysponowało szacunkowo 38 tys. miejsc noclegowych dla obsługi wypoczynku wakacyjno-urlopowego i letniskowego (w tym 23,5 tys. miejsc zapewniało organizowanie kolonii letnich). Standard tej bazy noclegowej był na ogół niski, ale gwarantował zaspokojenie dużego 
zapotrzebowania na letni wypoczynek wakacyjno-urlopowy mieszkańców regionu. Atrakcyjność tego typu bazy noclegowej malała od początku lat 70. ubiegłego wieku. Dlatego zwłaszcza przemysłowe zakłady pracy zaczęły inwestować we własne obiekty wypoczynkowe o stosunkowo wysokim standardzie, często umożliwiającym ich wykorzystanie całoroczne. Wraz z poprawą standardu tej bazy noclegowej ulokowanej w obecnych granicach województwa łódzkiego i systematycznym eliminowaniem z niej wcześniej wykorzystywanych (zwłaszcza na potrzeby organizacji kolonii) substandardowych obiektów sezonowych wzrosła ich jakość i utrzymana została pojemność ośrodków wypoczynkowych.

W regionie łódzkim ważną rolę spełniały i nadal spełniają obiekty zakwaterowania indywidualnego (kwatery prywatne, drugie domy itp.) obsługujące letniska. W 1970 roku dysponowały liczbą blisko 12 tys. miejsc. W 1990 roku według statystyki państwowej pojemność obiektów zakwaterowania indywidualnego wynosiła 1150 miejsc, co rozmijało się ze stanem faktycznym, ponieważ większość z nich nie dostarczała sprawozdań ze swojej działalności do GUS-u i nadal w ograniczonym stopniu wywiązuje się z tego obowiązku. Rzeczywista liczba miejsc noclegowych, którą takie obiekty dysponują jest wielokrotnie większa niż podają dane GUS-owskie. Natomiast systematycznie wzrastała liczba i pojemność pozostałych obiektów noclegowych, zwłaszcza hoteli, które w latach 1970-1990 zwiększyły niemal dwukrotnie liczbę miejsc noclegowych.

Po zmianach ustrojowych, w latach 1989-2017, rozwijała się komercyjna baza noclegowa, zwłaszcza hotelarska, natomiast systematycznie malała pojemność obiektów noclegowych obsługujących turystykę socjalną. Czterokrotny wzrost pojemności odnotowały hotele. Rozpowszechniły się one obecnie we wszystkich powiatach regionu, przy utrzymującej się nadal dużej koncentracji w Łodzi (blisko połowa). Wyodrębniona została grupa hosteli, która - ulokowana głównie w Łodzi - zwiększyła swoją pojemność dwunastokrotnie. Prawie dwukrotny wzrost pojemności odnotowały (według danych GUS-owskich) obiekty zakwaterowania indywidualnego. Natomiast trzykrotnie zmalała pojemność domów wycieczkowych i schronisk; w wielu powiatach zlikwidowano większość kempingów i pól biwakowych. Pojemność ośrodków wypoczynkowych zmalała o ponad połowę. W tej grupie jedynie ośrodki szkoleniowo-wypoczynkowe zwiększyły o trzy czwarte swoją pojemność (m.in. dzięki utrzymaniu, zwiększeniu i poprawie standardu przez dobrze prosperujących gestorów).

Drugą ważną zmianą obejmującą bazę noclegową w województwie łódzkim był dynamiczny wzrost liczby miejsc noclegowych całorocznych. W 2017 roku już tylko nieliczne obiekty działały wyłącznie sezonowo (15\%). Natomiast pozostałe dostępne były przez cały rok. Pod tym względem województwo 
miało większy udział tych miejsc w całkowitej pojemności bazy noclegowej niż przeciętnie w kraju.

Rozmieszczenie przestrzenne obiektów bazy noclegowej i jej pojemności nie uległo zasadniczym zmianom. Nadal przede wszystkim koncentrowało się w Łodzi i na jej zapleczu, w dolinie Pilicy wraz z Zalewem Sulejowskim oraz dolinie Warty z nadal dość ubogo zagospodarowanym pod względem bazy noclegowej zbiornikiem Jeziorsko. W niewielkim stopniu wzrosła pojemność bazy noclegowej na pozostałych obszarach województwa (m.in. wyraźny wzrost notowano $\mathrm{w}$ powiatach bełchatowskim i kutnowskim). Najbardziej w województwie łódzkim rozpowszechniły się hotele, a ich koncentracja przestrzenna wyraźnie zmalała. W wielu powiatach zniknęły domy wycieczkowe i schroniska (obsługujące wcześniej ruch wycieczkowy) oraz kempingi i pola biwakowe, co spowodowało istotny wzrost ich koncentracji przestrzennej. Ośrodki wypoczynkowe, pomimo spadku liczby miejsc noclegowych, utrzymały wcześniejszą strukturę przestrzenną. Natomiast według danych GUS-owskich zajmowany w województwie obszar systematycznie powiększały obiekty zakwaterowania indywidualnego.

Wielkość i struktura bazy noclegowej sytuuje województwo łódzkie na jednym $\mathrm{z}$ ostatnich miejsc w kraju. Wydaje się, że na ten stan rzeczy wplywa niska ocena walorów turystycznych. Województwo łódzkie na tle Polski nie wyróżnia się szczególną atrakcyjnością turystyczną. Według wskaźnika atrakcyjności turystycznej (WAT) zajmuje ono ostatnią pozycję w kraju (Turystyka w 2015 roku 2016). Wskaźnik ten dla województwa łódzkiego osiągnął najniższą w kraju wartość 3,041. Najwyższy WAT zyskało województwo małopolskie 12,112. Wskaźnik ten dla województw wyznaczono jako średnią arytmetyczną wskaźnika atrakcyjności turystycznej dla powiatów (uwzględniającego atrakcyjność środowiskową, kulturową i biznesowo-hotelową) wchodzących w ich skład.

Tabela 12. Wskaźnik atrakcyjności turystycznej (WAT) poszczególnych powiatów województwa lódzkiego

\begin{tabular}{|c|c|l|}
\hline WAT & $\begin{array}{c}\text { Liczba } \\
\text { powiatów }\end{array}$ & \multicolumn{1}{c|}{ Powiaty } \\
\hline 1 & 2 & 3 \\
\hline $0,78-2,60$ & 11 & $\begin{array}{l}\text { kutnowski, lęczycki, sieradzki, zduńskowolski, } \\
\text { wieruszowski, wieluński, pajęczański, radomszczański, } \\
\text { opoczyński, rawski, m. Skierniewice }\end{array}$ \\
\hline $2,60-3,78$ & 7 & $\begin{array}{l}\text { lowicki, skierniewicki, brzeziński, tomaszowski, } \\
\text { bełchatowski, laski, poddębicki }\end{array}$ \\
\hline
\end{tabular}


Tabela 12 (cd.)

\begin{tabular}{|l|c|l|}
\hline \multicolumn{1}{|c|}{1} & 2 & \multicolumn{1}{|c|}{3} \\
\hline $3,78-5,53$ & 5 & $\begin{array}{l}\text { piotrkowski, lódzki wschodni, pabianicki, zgierski, } \\
\text { m. Piotrków Trybunalski }\end{array}$ \\
\hline $5,53-8,34$ & 1 & m. Łódź \\
\hline $8,34-10,94$ & 0 & \\
\hline $10,94-13,62$ & 0 & \\
\hline $13,62-41,68$ & 0 & \\
\hline
\end{tabular}

Źródło: Turystyka w 2015 roku 2016.

Powiaty wchodzące w skład województwa łódzkiego charakteryzują się niską atrakcyjnością turystyczną (tab. 12). W odniesieniu do większości z nich wskaźnik WAT nie przekracza wartości dla całego województwa. Tylko w powiatach otaczających Łódź (łódzkim wschodnim, pabianickim, zgierskim) i piotrkowskim razem z Piotrkowem Trybunalskim kształtował się powyżej wielkości dla całego województwa. Najwyższą wartość WAT (w przedziale 5,53-8,34) uzyskała sama Łódź.

\subsection{Wykorzystanie turystycznej bazy noclegowej województwa łódzkiego}

Poziom wykorzystania (obłożenia) miejsc noclegowych - obok liczby obiektów i ich struktury oraz liczby miejsc noclegowych w nich i poziomu nasycenia rynku hotelarskiego - jest jednym z najważniejszych parametrów opisujących bazę noclegową danego obszaru (Włodarczyk 2014). Jako stopień (poziom) wykorzystania (obłożenia) miejsc noclegowych (lub pokoi) rozumiany jest stosunek liczby udzielonych noclegów (lub wynajętych pokoi) do nominalnej liczby miejsc noclegowych (pokoi) w danym okresie. Nominalna liczba miejsc noclegowych (pokoi) to suma miejsc noclegowych (pokoi) przygotowanych dla gości w każdym dniu działalności obiektu w przedziale czasowym, w którym przeprowadzano badanie (Milewska, Skrzypczyński, Włodarczyk 2004).

Według oficjalnych danych GUS-owskich w 2017 roku ze wszystkich turystycznych obiektów noclegowych zlokalizowanych w województwie lódzkim skorzystało łącznie 1307,7 tys. turystów, przy czym liczba ta wzrosła o 3,4\% w porównaniu z rokiem poprzednim. Największym obłożeniem cieszyly się hotele. W 2017 roku liczba osób nocujących w hotelach wyniosła 919,2 tys. (o 3,5\% więcej niż rok 
wcześniej) i stanowily one 70,3\% ogółu turystów korzystających z bazy noclegowej. Noclegi w innych obiektach hotelowych wybrało 138 tys. osób (10,6\% ogółu).

W2017 roku w województwie łódzkim udzielono łącznie 2342,9 tys. noclegów, tj. o 0,7\% więcej niż w poprzednim. Najwięcej w hotelach - 1423,6 tys., co stanowiło $60,8 \%$ ogólnej liczby noclegów. W motelach, pensjonatach i innych obiektach hotelowych nocowało łącznie 297,2 tys. osób (12,6\%). Na pozostałe obiekty przypadło 622,1 tys. noclegów, tj. 26,6\% ogółu udzielonych noclegów. W porównaniu z poprzednim rokiem liczba noclegów w obiektach hotelowych wzrosła o $1,8 \%$, natomiast w pozostałych obiektach zmalała o $2,2 \%$.

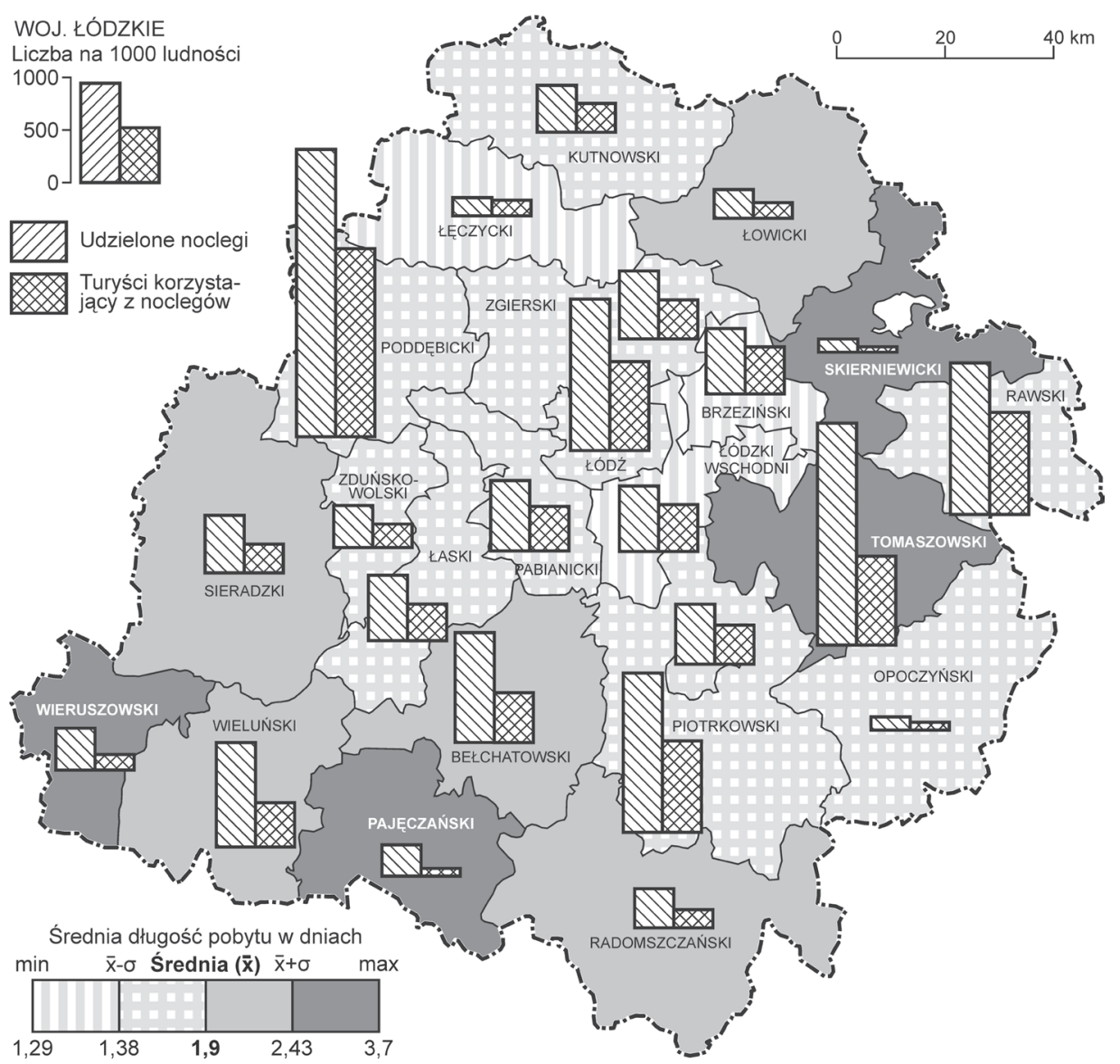

Rysunek 5. Zróżnicowanie przestrzenne średniej długość pobytu oraz liczby turystów i udzielonych noclegów na tysiąc mieszkańców w powiatach województwa łódzkiego w 2017 roku

Źródło: opracowanie własne za: Bank Danych Lokalnych, https://www.bdl.stat.gov.pl (dostęp: 20.03.2018) 
W 2017 roku najwięcej osób skorzystało z turystycznych obiektów noclegowych w Łodzi (wzrost o 9\% w stosunku do poprzedniego roku). Odwiedzający miasto stanowili 45,3\% ogółu turystów przybyłych do województwa łódzkiego, a ich udział w porównaniu z 2016 rokiem wzrósł o 2,7\%. Oprócz Łodzi wśród najczęściej odwiedzanych powiatów znalazły się: tomaszowski (100,5 tys. korzystających z noclegów), piotrkowski (78,4 tys.) i poddębicki (74,1 tys.). W 2017 roku najwięcej noclegów udzielono w Łodzi - 1002,7 tys., co stanowiło $43 \%$ wszystkich noclegów w województwie lódzkim (wzrost o 10,3\% w stosunku do poprzedniego roku). Wysoki odsetek udzielonych noclegów odnotowano również w powiatach tomaszowskim (10,6\%), poddębic$\operatorname{kim}(5,9 \%)$ i piotrkowskim $(4,8 \%)$.

Średnia długość pobytu w turystycznych obiektach bazy noclegowej województwa łódzkiego w 2017 roku wahała się od 1,29 doby w powiecie łęczyckim do 3,7 doby w powiecie pajęczańskim (rys. 5). Pobytem powyżej 2,5 dób, obok powiatu pajęczańskiego, charakteryzowały się jeszcze trzy powiaty: wieruszowski, skierniewicki i tomaszowski. W Łodzi średnia długość pobytu wyniosła 1,69 doby.

W przeliczeniu na tysiąc mieszkańców największej liczby noclegów udzielono w 2017 roku w powiecie poddębickim (2729 noclegów), tomaszowskim (2101), piotrkowskim (1506), rawskim (1447) i miejskim łódzkim (1445). Należy zwrócić uwagę, że w przedstawionym rankingu dominowały powiaty o największych walorach uzdrowiskowych (poddębicki) i wypoczynkowych (tomaszowski, piotrkowski, rawski). Pod względem liczby turystów przeliczanych na tysiąc mieszkańców w 2017 roku bezwzględnie dominował powiat poddębicki, gdzie wskaźnik ten wniósł 1789 turystów (rys. 5). W żadnym z pozostałych powiatów województwa łódzkiego wskaźnik ten nie przekroczył tysiąca osób.

\subsubsection{Miejsce województwa lódzkiego w strukturze wykorzystania turystycznych obiektów noclegowych w Polsce}

Fluktuacja wykorzystania obiektów noclegowych w Polsce wyraźnie nawiązuje do cyklu koniunkturalnego $w$ gospodarce światowej. Załamanie gospodarcze $\mathrm{w}$ końcu pierwszej dekady XXI wieku objawiło się również w branży hotelarskiej, m.in. zahamowaniem budowy nowych obiektów hotelarskich i zmniejszeniem stopnia wykorzystania pokoi oraz miejsc noclegowych (Włodarczyk 2014). Analiza aktualnych oficjalnych danych statystycznych pozwala postawić tezę, że niekorzystna koniunktura w branży turystycznej mija - świadczy o tym tendencja wzrostu zarówno odnośnie do liczby miejsc noclegowych, jak i wykorzystania (obłożenia) miejsc noclegowych w Polsce - od 2012 roku wykorzystanie to systematycznie rośnie, z 33,6\% do $39,3 \%$ w 2017 roku (tab. 13). Pomimo stałego wzrostu, wykorzystanie 


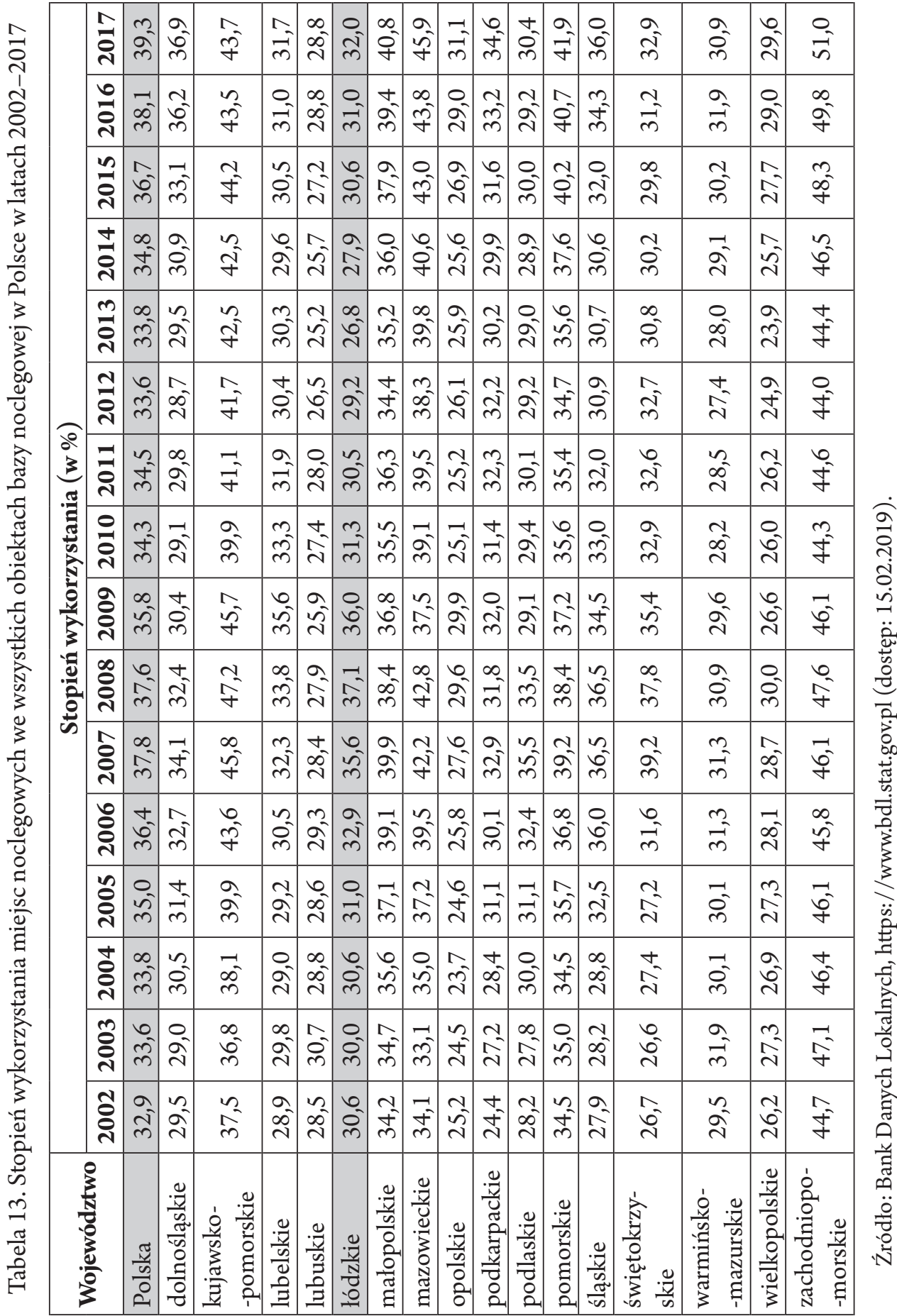


miejsc noclegowych w Polsce nie jest imponujące. W krajach takich jak Francja, Holandia czy Malta wskaźnik ten przekracza 60\% (Włodarczyk 2014), a np. w amerykańskim Las Vegas osiąga corocznie ponad 90\% (Kowalczyk 2001).

Województwo łódzkie, pomimo stałego wzrostu wykorzystania miejsc noclegowych (zwłaszcza w ostatnich pięciu latach), prezentuje się na tle Polski nader skromnie - osiągając 32\%, czyli o ponad 7\% mniej, niż średnia krajowa i o $19 \%$ mniej, niż w najlepiej wykorzystującym zasoby bazy noclegowej województwie zachodniopomorskim, gdzie w 2017 roku obłożenie miejsc noclegowych wyniosło $51 \%$. W ostatnim piętnastoleciu (za wyjątkiem roku 2009) wykorzystanie miejsc noclegowych w województwie było zawsze poniżej średniej ogólnopolskiej (tab. 13, rys. 6).

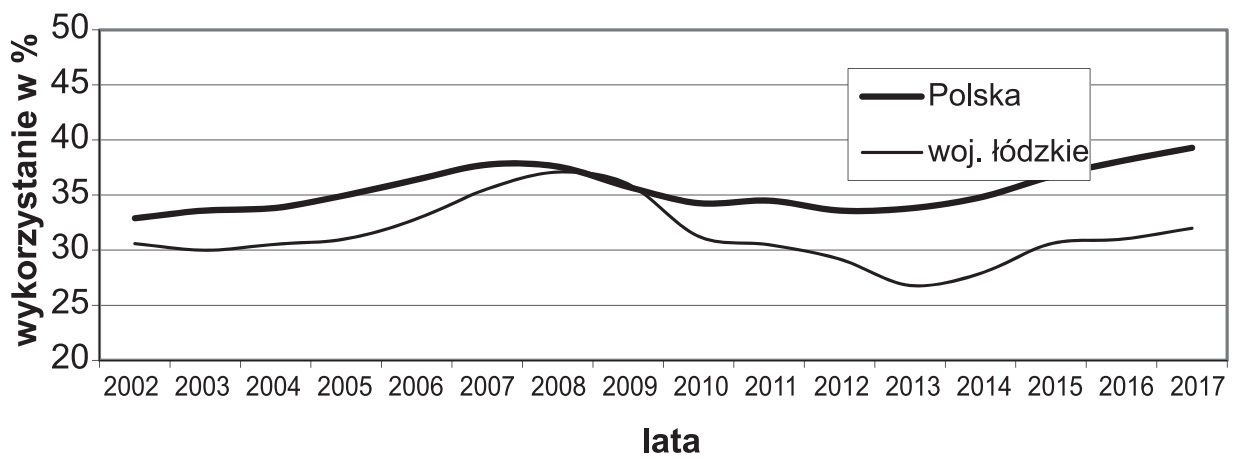

Rysunek 6. Wykorzystanie miejsc noclegowych bazy noclegowej województwa łódzkiego na tle Polski w latach 2002-2017

Źródło: opracowanie własne za: Bank Danych Lokalnych, https://www.bdl.stat.gov.pl (dostęp: 15.02.2019)

Potwierdzeniem niewielkiego stopnia wykorzystania miejsc noclegowych w województwie łódzkim na tle pozostałych województw jest dopiero jego dziesiąte miejsce w rankingu wykorzystania bazy noclegowej (tab. 14). Znajdowanie się na końcu pierwszej dziesiątki województw jest „pozycją wysoko niezadowalającą w kontekście ambicji rozwoju turystyki, jaką wykazują władze regionu i stolicy województwa" (Włodarczyk 2014: 363).

W ujęciu regionalnym najwyższym wykorzystaniem obiektów noclegowych, mogą poszczycić się województwa tradycyjnie uchodzące za atrakcyjne turystycznie: zachodniopomorskie (pierwsze miejsce pod względem wykorzystania obiektów hotelowych $(50,9 \%)$ i drugie - pozostałych obiektów $(51,1 \%)$ takich jak m.in. ośrodki wczasowe, kolonijne, szkoleniowo-wypoczynkowe czy kempingi), kujawsko-pomorskie (ósme miejsce w wykorzystaniu miejsc hotelowych $(33,1 \%)$ i pierwsze - obiektów niebędących hotelami $(54,5 \%))$, pomorskie (odpowiednio miejsca czwarte $(43,4 \%)$ i trzecie $(40,7 \%)$ ), małopolskie 
i dolnośląskie oraz województwo mazowieckie (gdzie decydującą rolę odgrywa wykorzystanie miejsc w obiektach hotelowych - 49,3\%) (tab. 14). Na tym tle wykorzystanie obiektów noclegowych w województwie lódzkim nie wygląda imponująco - pod względem wykorzystania obiektów hotelowych województwo plasuje się na dziewiątym miejscu (z wykorzystaniem na poziomie 33,1\%), a pozostałych obiektów dopiero na dwunastej pozycji (29,3\%).

Tabela 14. Miejsce województwa łódzkiego w strukturze wykorzystania miejsc noclegowych w Polsce w 2017 roku

\begin{tabular}{|c|c|c|c|c|c|c|}
\hline \multirow[b]{2}{*}{ Województwo } & \multicolumn{2}{|c|}{$\begin{array}{l}\text { Wszystkie } \\
\text { obiekty }\end{array}$} & \multicolumn{2}{|c|}{$\begin{array}{l}\text { Obiekty } \\
\text { hotelowe }\end{array}$} & \multicolumn{2}{|c|}{$\begin{array}{c}\text { Pozostałe } \\
\text { obiekty }\end{array}$} \\
\hline & $\%$ & $\begin{array}{c}\text { miejsce } \\
\text { w Polsce }\end{array}$ & $\%$ & $\begin{array}{c}\text { miejsce } \\
\text { w Polsce }\end{array}$ & $\%$ & $\begin{array}{c}\text { miejsce } \\
\text { w Polsce }\end{array}$ \\
\hline Polska & 39,3 & & 39,8 & & 38,5 & \\
\hline zachodniopomorskie & 51,0 & 1 & 50,9 & 1 & 51,1 & 2 \\
\hline mazowieckie & 45,9 & 2 & 49,3 & 2 & 32,1 & 10 \\
\hline kujawsko-pomorskie & 43,7 & 3 & 33,1 & 8 & 54,5 & 1 \\
\hline pomorskie & 41,9 & 4 & 43,4 & 4 & 40,7 & 3 \\
\hline małopolskie & 40,8 & 5 & 47,1 & 3 & 33,7 & 8 \\
\hline dolnośląskie & 36,9 & 6 & 37,7 & 5 & 35,7 & 6 \\
\hline śląskie & 36,0 & 7 & 36,2 & 6 & 35,7 & 7 \\
\hline podkarpackie & 34,6 & 8 & 31,5 & 12 & 37,6 & 5 \\
\hline świętokrzyskie & 32,9 & 9 & 29,5 & 16 & 38,3 & 4 \\
\hline lódzkie & 32,0 & 10 & 33,1 & 9 & 29,3 & 12 \\
\hline lubelskie & 31,7 & 11 & 30,6 & 14 & 33,3 & 9 \\
\hline opolskie & 31,1 & 12 & 31,8 & 11 & 30,2 & 11 \\
\hline warmińsko-mazurskie & 30,9 & 13 & 34,0 & 7 & 26,1 & 15 \\
\hline podlaskie & 30,4 & 14 & 33,0 & 10 & 26,6 & 14 \\
\hline wielkopolskie & 29,6 & 15 & 31,5 & 13 & 25,7 & 16 \\
\hline lubuskie & 28,8 & 16 & 30,2 & 15 & 26,8 & 13 \\
\hline
\end{tabular}

Źródło: opracowanie własne za: Bank Danych Lokalnych, https://www.bdl.stat. gov.pl (dostęp: 15.02.2019). 


\subsubsection{Struktura wykorzystania turystycznych obiektów noclegowych w województwie łódzkim}

W 2017 roku stopień wykorzystania miejsc noclegowych w województwie łódzkim wyniósł $32 \%$, co stanowiło wzrost o $1 \%$ w stosunku do roku poprzedniego (tab. 15).

Najwyższe obłożenie odnotowano w zakładach uzdrowiskowych - 83,6\% (w jedynym takim obiekcie w Uniejowie), ośrodkach kolonijnych - 71,9\%, schroniskach młodzieżowych - 36,2\% i hotelach - 35,2\%. Najniższym wskaźnikiem wykorzystania miejsc noclegowych charakteryzowały się pensjonaty - 8,4\%, kwatery agroturystyczne - 10,2\% i szkolne schroniska młodzieżowe $-12,7 \%$ (rys. 7 ).

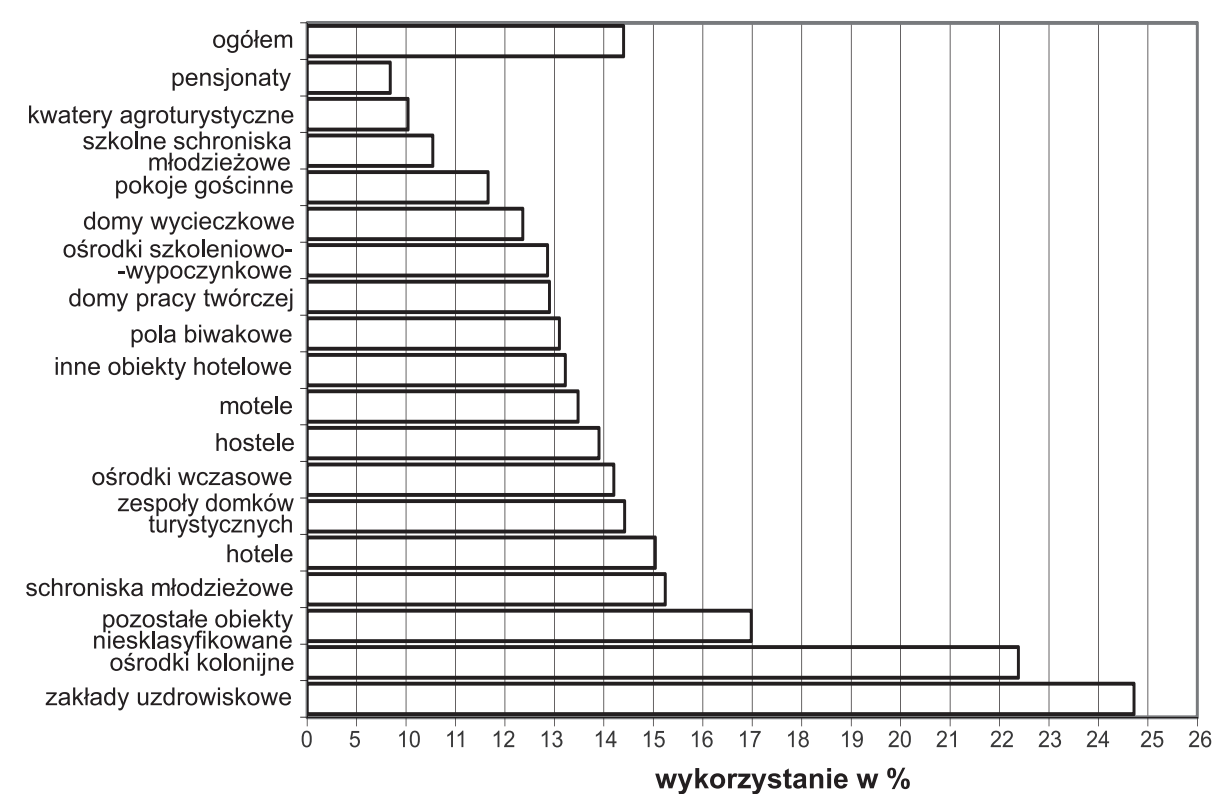

Rysunek 7. Struktura wykorzystania obiektów bazy noclegowej województwa łódzkiego w 2017 roku

Źródło: opracowanie własne za: Bank Danych Lokalnych, https://www.bdl.stat.gov.pl (dostęp: 15.02.2019)

Stopień wykorzystania bazy noclegowej województwa łódzkiego podlegał w ostatnim piętnastoleciu znacznym fluktuacjom - najniższe obłożenie odnotowano w 2013 roku (26,8\%), najwyższe w 2008 roku (37,1\%). Najmniejsze wahania obłożenia odnotowały w owym czasie zakłady uzdrowiskowe, pokoje gościnne oraz hotele i motele. Największym spadkiem wykorzystania miejsc noclegowych cechowały się pensjonaty (z 77,6\% do 


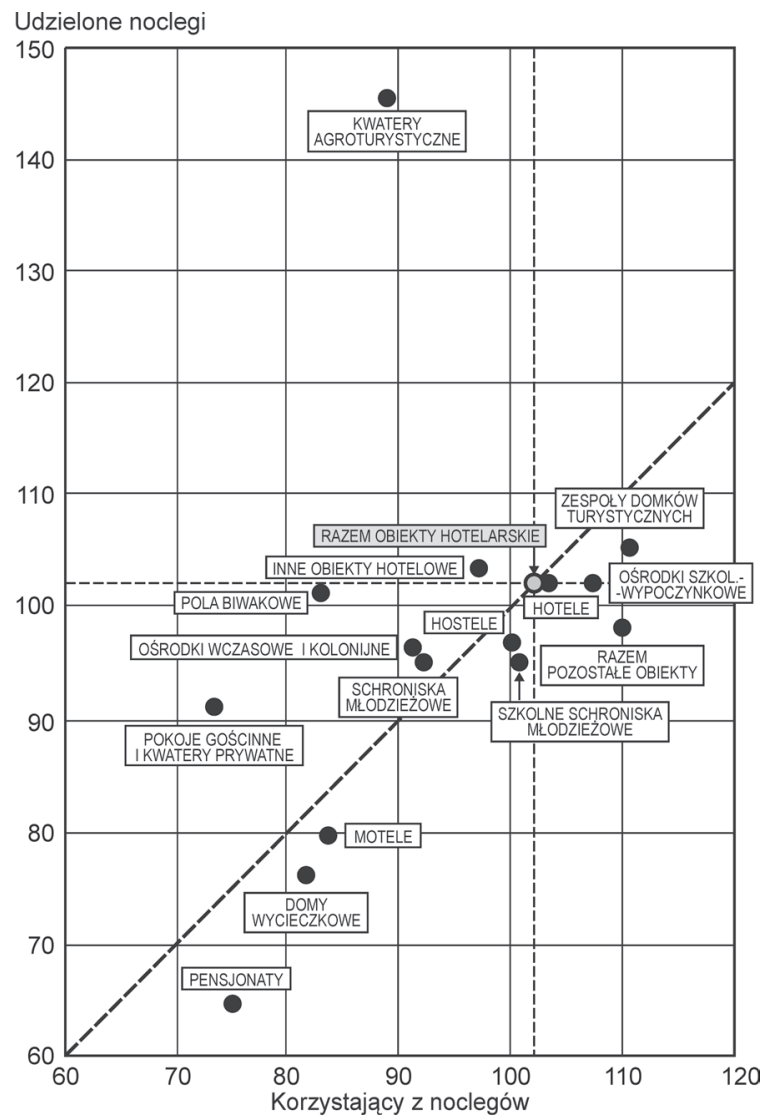

Rysunek 8. Indeks wykorzystania bazy noclegowej poszczególnych rodzajów w województwie łódzkim w latach 2016-2017 (2016 rok = 100)

Źródło: opracowanie własne za: Bank Danych Lokalnych, https://www.bdl.stat.gov.pl (dostęp: 15.02.2019)

$8,4 \%$, odpowiednio w latach w 2005 i 2017) i domy wycieczkowe (z 60\% do $21,8 \%$, odpowiednio w latach w 2006 i 2017).

W roku 2017 największą dynamiką wzrostu indeksu wykorzystania miejsc noclegowych $\mathrm{w}$ stosunku do roku poprzedniego charakteryzowały się kwatery agroturystyczne (rys. 8). Pod względem liczby udzielonych noclegów indeks wzrósł w tym wypadku prawie o 50\%, mimo że liczba turystów korzystających $\mathrm{z}$ takiego rodzaju zakwaterowania nieco zmalała (świadczy to o postępującym wzroście długości czasu korzystania z obiektów agroturystycznych). Na przeciwnym biegunie w analogicznym okresie znalazły się pensjonaty, domy wycieczkowe i motele, które zarówno pod względem liczby korzystających, jak i liczby udzielonych noclegów odnotowały spadki od dwudziestu do trzydziestu paru procent. 


\begin{tabular}{|c|c|c|c|c|c|c|c|c|c|c|}
\hline \multirow{4}{*}{ 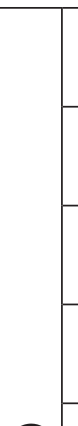 } & $\overrightarrow{\mathrm{d}}$ & 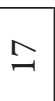 & iे & ले & $\begin{array}{l}2 \\
2 \\
m\end{array}$ & 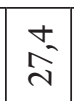 & $\underset{\infty}{+}$ & $\overrightarrow{5}$ & $\hat{\sigma}^{2}$ & $\begin{array}{l}\infty \\
\vec{\sim}\end{array}$ \\
\hline & 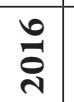 & $\stackrel{0}{-1}$ & $\frac{0}{m}$ & के & $\vec{F}$ & 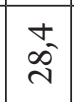 & $\vec{m}$ & $\widehat{\vec{n}}$ & הี & ర్ \\
\hline & בై & $\simeq$ & $\begin{array}{l}0 \\
\text { है } \\
\text { - }\end{array}$ & $\bar{m}$ & $\stackrel{m}{2}^{2}$ & \begin{tabular}{l|}
0 \\
$\mathbf{a}^{2}$
\end{tabular} & $\hat{n}$ & $\tilde{n}$ & สิ & ते \\
\hline & ت্ं & \pm & ते & 吕 & \begin{tabular}{l|} 
\\
\\
0 \\
0
\end{tabular} & $\hat{\tilde{i}}$ & $\begin{array}{l}0 \\
\text { ñ }\end{array}$ & $\stackrel{\infty}{\vec{\lambda}}$ & tث & $\infty$ \\
\hline 2 & $\begin{array}{l}m \\
\stackrel{\pi}{n}\end{array}$ & $\stackrel{\oplus}{-}$ & $\begin{array}{l}\infty \\
\text { فे } \\
\text { ". }\end{array}$ & $\overrightarrow{\mathrm{i}}$ & $\mid \begin{array}{c}2 \\
\stackrel{0}{0}^{2}\end{array}$ & $\overrightarrow{\mathrm{s}}$ & $\hat{\sigma}$ & ì & 吕 & $3^{2}$ \\
\hline 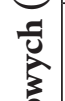 & 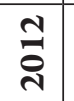 & $\simeq$ & ते & $\underset{\text { के }}{\stackrel{a}{\sim}}$ & $\begin{array}{l}\hat{0} \\
\bar{n}\end{array}$ & $\begin{array}{l}0 \\
\mathrm{i}\end{array}$ & $\begin{array}{l}n \\
\stackrel{n}{n}\end{array}$ & $\stackrel{+}{+}$ & $\begin{array}{l}\infty \\
\hat{i}^{\infty}\end{array}$ & $\underset{\infty}{+}$ \\
\hline 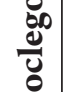 & $\overline{\vec{\lambda}}$ & $\exists$ & है & iे & $\stackrel{ }{m}$ & $\mid \begin{array}{c}m \\
\hat{N} \\
\tilde{n}\end{array}$ & $\begin{array}{l}0 \\
=\end{array}$ & $\overrightarrow{\mathrm{d}}$ & $\frac{0}{m}$ & $b^{-}$ \\
\hline $\begin{array}{l}5 \\
0 \\
0.0\end{array}$ & 节 & $\stackrel{9}{1}$ & $\frac{m}{m}$ & s. & $\vec{m}$ & $\overrightarrow{\tilde{n}^{\prime}}$ & $\stackrel{\partial}{\exists}$ & $\vec{a}$ & $\vec{m}$ & $\begin{array}{l}\infty \\
\tilde{q} \\
\tilde{q}\end{array}$ \\
\hline & $\stackrel{\text { ڤ్ }}{\mathrm{N}}$ & $a$ & $\begin{array}{l}0 \\
\hat{n}^{-}\end{array}$ & $\begin{array}{l}\text { वे } \\
\text { से }\end{array}$ & 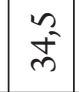 & $\mid \begin{array}{c}c \\
\infty \\
\infty \\
n\end{array}$ & $\begin{array}{l}0 \\
15 \\
n\end{array}$ & $\vec{m}$ & $\hat{\bar{m}}$ & $\stackrel{+}{\vec{n}}$ \\
\hline 离 & 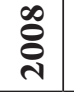 & $\infty$ & $\bar{m}$ & $\begin{array}{l}\infty \\
n^{0}\end{array}$ & $\begin{array}{c}2 \\
\tilde{m}\end{array}$ & $\overrightarrow{0}=$ & 1 & $\overrightarrow{\tilde{n}}$ & $\sigma^{2}$ & हु- \\
\hline 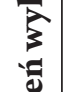 & ث્సે & $n$ & ì & iे & 咅 & $\begin{array}{l}a \\
\hat{n} \\
\tilde{n}\end{array}$ & $\tilde{\delta}$ & $\stackrel{0}{m}$ & is & $\therefore$ \\
\hline 菅 & 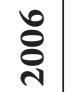 & 0 & ते & $\hat{m}$ & $\begin{array}{l}\hat{\sigma} \\
\hat{\delta}\end{array}$ & $\overrightarrow{\tilde{n}}$ & $\begin{array}{l}t \\
b \\
b\end{array}$ & $\underset{d}{+}$ & $\hat{m}$ & $\begin{array}{l}0 \\
\stackrel{\gamma}{7}\end{array}$ \\
\hline & 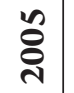 & $n$ & $\frac{0}{m}$ & $\frac{\partial}{m}$ & $\stackrel{+}{m}$ & $\begin{array}{c}m \\
\tilde{N} \\
\tilde{n}\end{array}$ & $\frac{0}{i}$ & $\stackrel{+}{\stackrel{\Delta}{N}}$ & बे & $a$ \\
\hline & 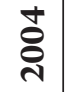 & $\nabla$ & : & $\overline{\mathrm{s}}$ & $\begin{array}{l}n \\
\tilde{m}\end{array}$ & $\begin{array}{l}\tilde{a} \\
\stackrel{2}{2}\end{array}$ & $\begin{array}{l}n \\
\hat{n}\end{array}$ & $\vec{N}$ & $=$ & $\begin{array}{l}\infty \\
\infty^{\infty}\end{array}$ \\
\hline & 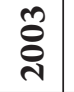 & $m$ & : & $\overline{\text { iे }}$ & $\hat{i}$ & 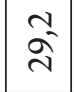 & iे & 1 & $\begin{array}{l}0 \\
\stackrel{0}{0}\end{array}$ & \\
\hline & స్తి & $N$ & $\begin{array}{l}0 \\
\stackrel{-}{0}\end{array}$ & $\hat{\text { sे }}$ & ते & $\hat{n}$ & $\stackrel{\infty}{i^{-}}$ & 1 & s & $\stackrel{\infty}{\infty}$ \\
\hline 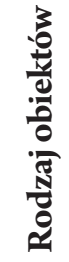 & 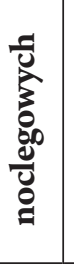 & $\neg$ & 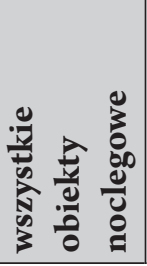 & 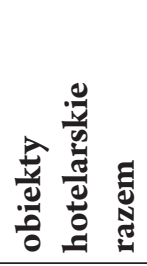 & 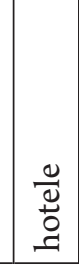 & 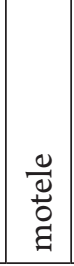 & 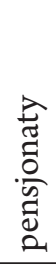 & 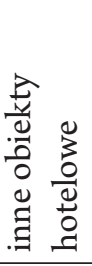 & 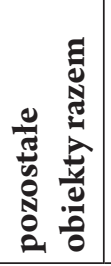 & ج્वे \\
\hline
\end{tabular}




\begin{tabular}{|c|c|c|c|c|c|c|c|c|c|c|}
\hline D & 1 & $\begin{array}{l}\text { ते } \\
\text { हn }\end{array}$ & $\widehat{\cong}$ & $\frac{0}{m}$ & $\stackrel{a}{\vec{r}}$ & $\stackrel{?}{\stackrel{\sim}{d}}$ & $\stackrel{2}{ \pm}$ & तै & 1 & $\stackrel{n}{\sim}$ \\
\hline$\underset{1}{0}$ & 1 & 家 & $\cong$ & $\stackrel{+}{\sim}$ & $\stackrel{0}{\infty}$ & $\begin{array}{l}\infty \\
\sim \\
\sim\end{array}$ & à & O & 1 & $\vec{N}$ \\
\hline$\approx$ & $\begin{array}{l}0 \\
\pm \\
\pm\end{array}$ & $\begin{array}{l}\text { ․ } \\
\text { ते }\end{array}$ & $\stackrel{\sim}{n}$ & बे & $\begin{array}{l}0 \\
8 \\
8\end{array}$ & $\stackrel{\sim}{\sim}$ & $\overrightarrow{\mathrm{n}}$ & $\begin{array}{l}0 \\
\text { ని }\end{array}$ & 1 & $a$ \\
\hline \pm & $\stackrel{0}{=}$ & $\begin{array}{l}n \\
\stackrel{2}{m}\end{array}$ & $\overbrace{}^{2}$ & $\begin{array}{l}0 \\
\vec{f}\end{array}$ & $\cong$ & $\begin{array}{l}0 \\
\stackrel{+}{d}\end{array}$ & $\begin{array}{l}0 \\
\stackrel{0}{=}\end{array}$ & $\begin{array}{l}0 \\
\stackrel{n}{\sim}\end{array}$ & 1 & $\cong$ \\
\hline$\stackrel{m}{\sim}$ & $\stackrel{\infty}{=}$ & $\stackrel{+}{\circ}$ & 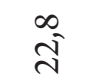 & 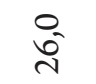 & $\begin{array}{l}0 \\
\text { ô } \\
\text { Nis }\end{array}$ & $\begin{array}{l}0 \\
\stackrel{\sim}{N}\end{array}$ & $\hat{\approx}$ & $\begin{array}{l}n \\
\tilde{e}^{2}\end{array}$ & 1 & $\stackrel{ \pm}{N}$ \\
\hline 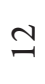 & $\stackrel{+}{+}$ & 定 & \pm & $\begin{array}{l}\infty \\
\sim \\
\sim\end{array}$ & $\stackrel{\sim}{\sim}$ & $\begin{array}{l}\infty \\
\sim \\
\sim\end{array}$ & $\tilde{\mathrm{d}}$ & $\begin{array}{c}\text { ते } \\
\text { हn }\end{array}$ & $\stackrel{\infty}{\sigma}$ & aे \\
\hline$\beth$ & å & స్ & $\overrightarrow{b^{-}}$ & 긍 & $\stackrel{\sim}{f}$ & $\hat{\sim}$ & $\begin{array}{l}0 \\
\text { do }\end{array}$ & $\tilde{n}$ & $\begin{array}{l}6 \\
\text { in }\end{array}$ & $\begin{array}{l}0 \\
n\end{array}$ \\
\hline$\stackrel{0}{\circ}$ & $\stackrel{+}{0}$ & $\stackrel{+}{m}$ & $\overbrace{}^{2}$ & $\hat{\tilde{o}}$ & ळे & స్ & $\begin{array}{l}\infty \\
\sim \\
\sim\end{array}$ & $\begin{array}{l}n \\
\infty \\
m^{-}\end{array}$ & పू & $\approx$ \\
\hline$a$ & $\infty^{\infty}$ & $\tilde{a}$ & 궁 & $\stackrel{m}{m^{\infty}}$ & $\begin{array}{l}\text { No } \\
\delta^{-}\end{array}$ & $\stackrel{n}{n^{\prime}}$ & $\begin{array}{l}\infty \\
\underset{d}{d}\end{array}$ & $\begin{array}{l}n \\
\stackrel{n}{n}\end{array}$ & $\begin{array}{l}\infty \\
\stackrel{-}{\sim}\end{array}$ & $\begin{array}{l}\infty \\
a^{-}\end{array}$ \\
\hline$\infty$ & $\begin{array}{l}0 \\
\infty\end{array}$ & $\stackrel{N}{\infty}$ & $\stackrel{a}{\approx}$ & $\begin{array}{l}0 \\
\stackrel{0}{d}\end{array}$ & $\frac{ \pm}{a}$ & $\begin{array}{l}\infty \\
\infty \\
\infty \\
\infty\end{array}$ & $\stackrel{n}{\tilde{n}}$ & $\begin{array}{l}0 \\
0 \\
6\end{array}$ & $\stackrel{\approx}{\approx}$ & $\begin{array}{l}n \\
\infty \\
m\end{array}$ \\
\hline$\Lambda$ & $\underset{\Delta}{\Delta}$ & $\stackrel{0}{\stackrel{0}{n}}$ & $\begin{array}{l}\infty \\
\infty^{-} \\
\sim\end{array}$ & $\stackrel{\sim}{\sim}$ & 2 & $\stackrel{+}{\circ}$ & $\stackrel{+}{\sim}$ & $\stackrel{q}{f}$ & $\stackrel{2}{\cong}$ & $\stackrel{\sim}{n}$ \\
\hline 6 & б) & $\begin{array}{l}0 \\
\infty^{-} \\
m\end{array}$ & $\begin{array}{l}0 \\
\stackrel{\sim}{N}\end{array}$ & $\begin{array}{l}\approx \\
\text { in } \\
\text { s. }\end{array}$ & $\stackrel{+}{\circ}$ & $\hat{\tilde{o}}$ & $\stackrel{\nabla}{\sim}$ & $\stackrel{\infty}{\stackrel{\infty}{+}}$ & $\vec{d}$ & $\stackrel{\sim}{\simeq}$ \\
\hline$n$ & $\hat{n}$ & 命 & $\stackrel{\circ}{2}$ & $\hat{\sim}$ & $\begin{array}{l}0 \\
8 \\
\Omega\end{array}$ & $\stackrel{2}{\infty}$ & \begin{tabular}{l}
0 \\
\multirow{N}{*}{}
\end{tabular} & $\begin{array}{l}m \\
\stackrel{m}{m}\end{array}$ & $\begin{array}{l}\stackrel{0}{ \pm} \\
\underset{\sim}{N}\end{array}$ & $\tilde{\sigma}^{2}$ \\
\hline$\nabla$ & in & $\begin{array}{l}+ \\
\dot{f}\end{array}$ & $\begin{array}{l}\infty \\
\infty \\
\infty\end{array}$ & $\stackrel{2}{\sim}$ & $\tilde{\infty}_{\infty}^{n}$ & ঠ্ & $\begin{array}{l}0 \\
\infty^{-}\end{array}$ & ๙ิ & $\begin{array}{l}0 \\
\stackrel{-}{d}\end{array}$ & $\cong$ \\
\hline$m$ & 1 & 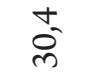 & 1 & $\begin{array}{l}+ \\
\text { ó }\end{array}$ & के & $\stackrel{\overbrace{}}{n}$ & ลิ & $\stackrel{\infty}{\text { న }}$ & $\stackrel{2}{n}$ & $\tilde{O}^{n}$ \\
\hline N & 1 & $\stackrel{2}{\approx}$ & 1 & $\tilde{a}^{2}$ & $\begin{array}{l}\circ \\
\infty \\
\infty\end{array}$ & बे & $\stackrel{n}{n}$ & $\stackrel{\sim}{m}$ & $\vec{\sim}$ & $\stackrel{0}{=}$ \\
\hline- & 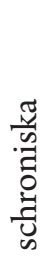 & 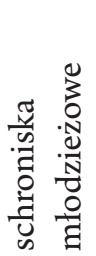 & 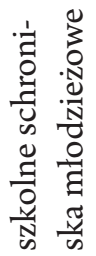 & 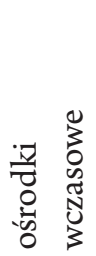 & 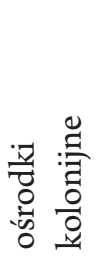 & 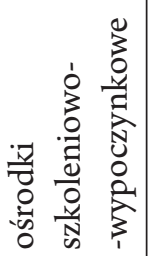 & 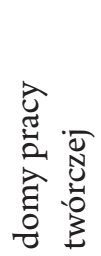 & 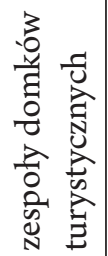 & 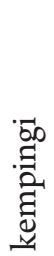 & 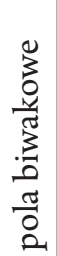 \\
\hline
\end{tabular}




\begin{tabular}{|c|c|c|c|c|c|c|}
\hline$\beth$ & 1 & ๙े & $\tilde{\sigma}$ & $\begin{array}{l}0 \\
\infty^{-}\end{array}$ & $\stackrel{g}{f}$ & $\infty^{\infty}$ \\
\hline$\underset{-1}{0}$ & 1 & $\hat{\sigma}$ & oิ & ळे & $\stackrel{n}{q}$ & $\stackrel{0}{9}$ \\
\hline$\cong$ & 1 & $\stackrel{+}{+}$ & ă & $\vec{\infty}$ & $\hat{\bar{o}}$ & $\overrightarrow{8}$ \\
\hline \pm & 1 & $\begin{array}{l}0 \\
0^{-} \\
m\end{array}$ & $\stackrel{\Omega}{\wedge}$ & $\hat{\infty}$ & $\ddot{n}$ & $\stackrel{2}{\infty}$ \\
\hline$\ddot{n}$ & 1 & $\begin{array}{l}\stackrel{0}{0} \\
\text { ते }\end{array}$ & $\stackrel{m}{n}$ & 1 & $\stackrel{\infty}{\infty}$ & $\stackrel{0}{\stackrel{n}{N}}$ \\
\hline$\stackrel{\sim}{\sim}$ & 1 & $\stackrel{+}{\stackrel{+}{0}}$ & $\vec{b}$ & 1 & $\begin{array}{l}\infty \\
b^{-} \\
n^{-}\end{array}$ & $\stackrel{0}{\stackrel{0}{N}}$ \\
\hline$\beth$ & 1 & $\hat{\tilde{m}}$ & 1 & 1 & $\hat{o}$ & 1 \\
\hline 으 & 1 & $\stackrel{m}{\infty^{-}}$ & 1 & 1 & $\widehat{\widetilde{f}}$ & 1 \\
\hline$a$ & 1 & $\tilde{n}$ & 1 & 1 & $\begin{array}{l}a \\
b^{-}\end{array}$ & 1 \\
\hline$\infty$ & $\tilde{a}$ & 1 & 1 & 1 & $\underset{+}{+}$ & 1 \\
\hline$\Lambda$ & ठे & 1 & 1 & 1 & $\stackrel{\infty}{\tilde{P}^{-}}$ & 1 \\
\hline 6 & $\overrightarrow{ \pm}$ & 1 & 1 & 1 & $\hat{\tilde{o}}$ & 1 \\
\hline$n$ & $\stackrel{ }{ }$ & 1 & 1 & 1 & $\hat{\mathrm{d}}$ & 1 \\
\hline+ & $\stackrel{-}{\circ}$ & 1 & 1 & 1 & $\stackrel{\circ}{\text { ஸे }}$ & 1 \\
\hline$m$ & 1 & 1 & 1 & 1 & $\widehat{\widehat{\sigma}}$ & 1 \\
\hline$\sim$ & 1 & 1 & \begin{tabular}{l}
0 \\
\multirow{n}{*}{}
\end{tabular} & 1 & $\begin{array}{l}2 \\
\text { on } \\
\text { n' }\end{array}$ & 1 \\
\hline$\neg$ & 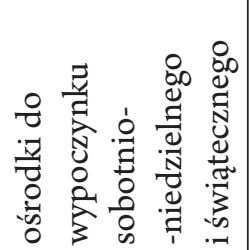 & 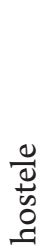 & 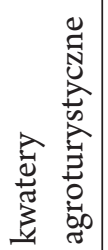 & 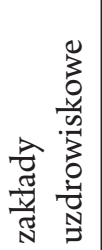 & 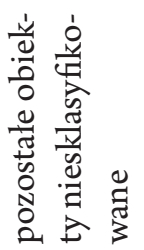 & 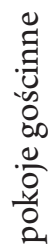 \\
\hline
\end{tabular}


Potencjał i wykorzystanie turystycznej bazy noclegowej...

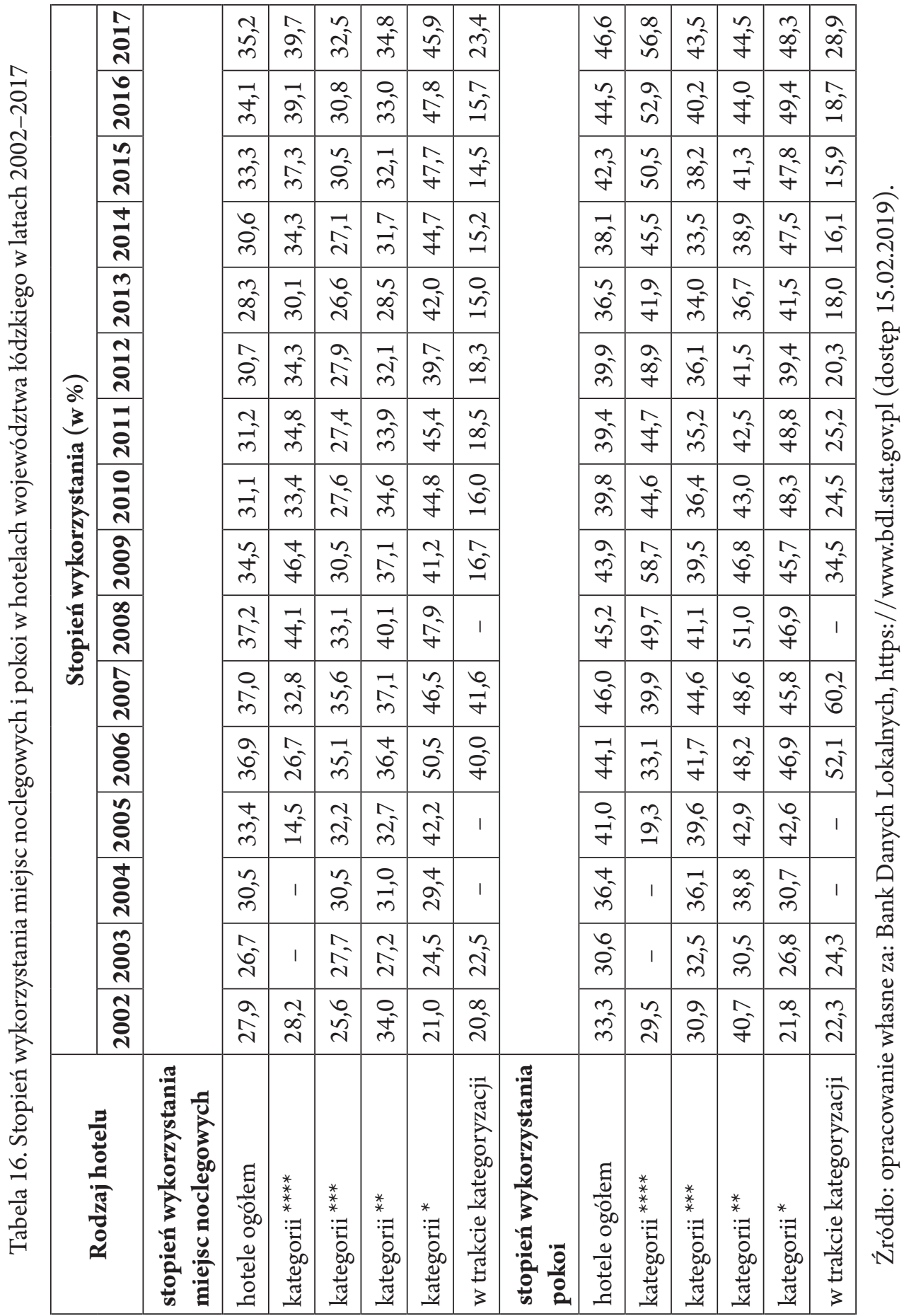


Jak wcześniej wspomniano, stopień wykorzystania hoteli w województwie łódzkim nie jest imponujący (jest co prawda o 3,2\% wyższy, niż średnio dla wszystkich obiektów noclegowych, lecz znacznie odbiega od wskaźników najlepszych zakładów uzdrowiskowych i ośrodków kolonijnych). Spośród hoteli największym wykorzystaniem miejsc noclegowych w 2017 roku charakteryzowały się obiekty o najniższej (jednogwiazdkowej - 45,9\%) i najwyższej kategorii (czterogwiazdkowej - 39,7\%); najniższym - obiekty trzygwiazdkowe $(32,5 \%)$ (tab. 16).

Odmiennie przedstawia się wykorzystanie pokoi w hotelach. W 2017 roku największym cechowały się obiekty o najwyższym standardzie (czterogwiazdkowe - 56,8\%) - jest to sytuacja zrozumiała, bo pokoje dwuosobowe w biznesowych hotelach czterogwiazdkowych najczęściej wykorzystywane są jako tzw. jedynki. Podobna tendencja (lepsze wykorzystanie pokoi w stosunku do miejsc noclegowych) zarysowuje się w hotelach wszystkich kategorii, lecz w wypadku czterogwiazdkowych zależność ta jest największa.

$\mathrm{Z}$ analizy tabeli 16. wynika, że po zawirowaniach w latach 2009-2012, od 2013 roku najbardziej wzrasta wykorzystanie miejsc noclegowych w hotelach o najwyższych kategoriach (cztero- i trzygwiazdkowych). Hotele o najniższym standardzie dotyka stagnacja (choć nadal jeszcze przodują pod względem obłożenia, czego oczywistym powodem jest cena miejsca noclegowego). Jeszcze wyraźniej widać tę zależność w wypadku wykorzystania pokoi.

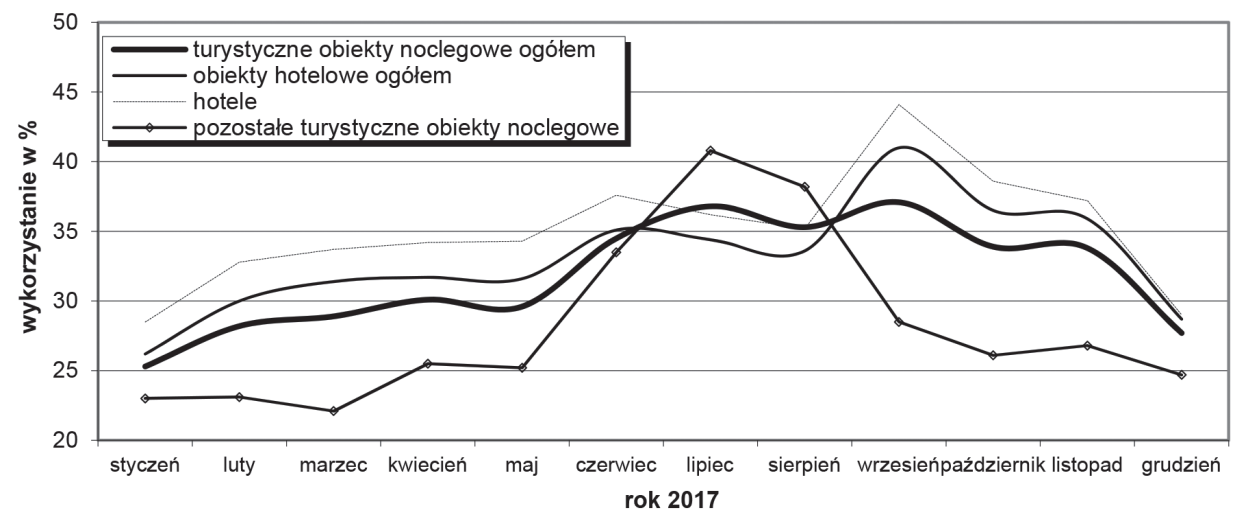

Rysunek 9. Sezonowość wykorzystania obiektów bazy noclegowej województwa łódzkiego w roku 2017

Źródło: opracowanie własne za: Bank Danych Lokalnych, https://www.bdl.stat.gov.pl (dostęp 15.02.2019) 
Potencjał i wykorzystanie turystycznej bazy noclegowej...

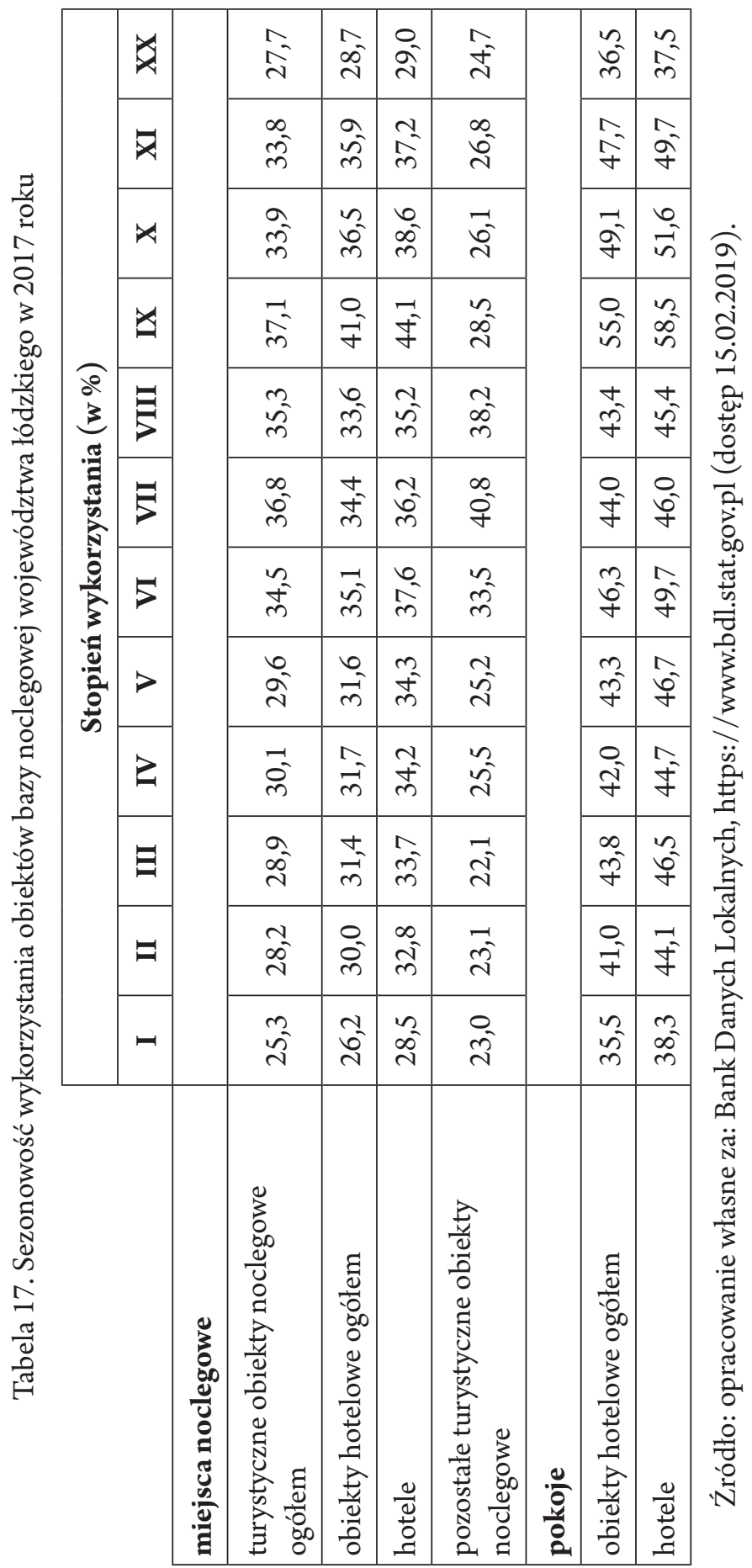


Jednym z najważniejszych parametrów opisujących sposób wykorzystania miejsc noclegowych na danym obszarze jest sezonowość. W województwie lódzkim stopień wykorzystania wszystkich turystycznych obiektów noclegowych w 2017 roku wahał się od 25,3\% w styczniu do blisko 37\% w lipcu i wrześniu (rys. 9, tab. 17). Biorąc pod uwagę np. sezonowość na obszarach nadmorskich (czy innych uznawanych tradycyjnie za wypoczynkowe) można stwierdzić, że w wypadku wszystkich obiektów bazy noclegowej województwa łódzkiego trudno jest mówić o sezonowości zaznaczającej się w takim stopniu, jak ma to miejsce np. w rejonach nadmorskich (lipiec-sierpień) - wzrost wykorzystania bazy noclegowej następuje w czerwcu i trwa do listopada (czyli pół roku).

Największą sezonowością w 2017 roku charakteryzowały się obiekty zaliczane przez GUS do kategorii „pozostałe turystyczne obiekty noclegowe”. Zdecydowany wzrost ich wykorzystania następował w maju, a kończył na przełomie września i października ( $\mathrm{z}$ widocznym szczytem w lipcu i sierpniu). Zjawisko to jest typowe dla tego rodzaju obiektów, bo do tej kategorii zalicza się te obiekty, które działają często jedynie w sezonie wiosenno-jesiennym, takie jak obiekty kolonijne czy różnego rodzaju ośrodki wczasowo-wypoczynkowe. Poza tym trzeba stwierdzić, że wykorzystanie tego rodzaju obiektów w szczycie sezonu na poziomie $38-40 \%$ jest w wysokim stopniu niezadowalające.

Mniejszą sezonowością charakteryzowały się obiekty hotelowe (także same hotele). W ich wypadku obserwowano dwa „szczyty obłożenia”: pierwszy - mniejszy, w czerwcu (37-35\%) i drugi - większy, trwający od września do października (34-38\%). Zdecydowana większość obiektów hotelowych

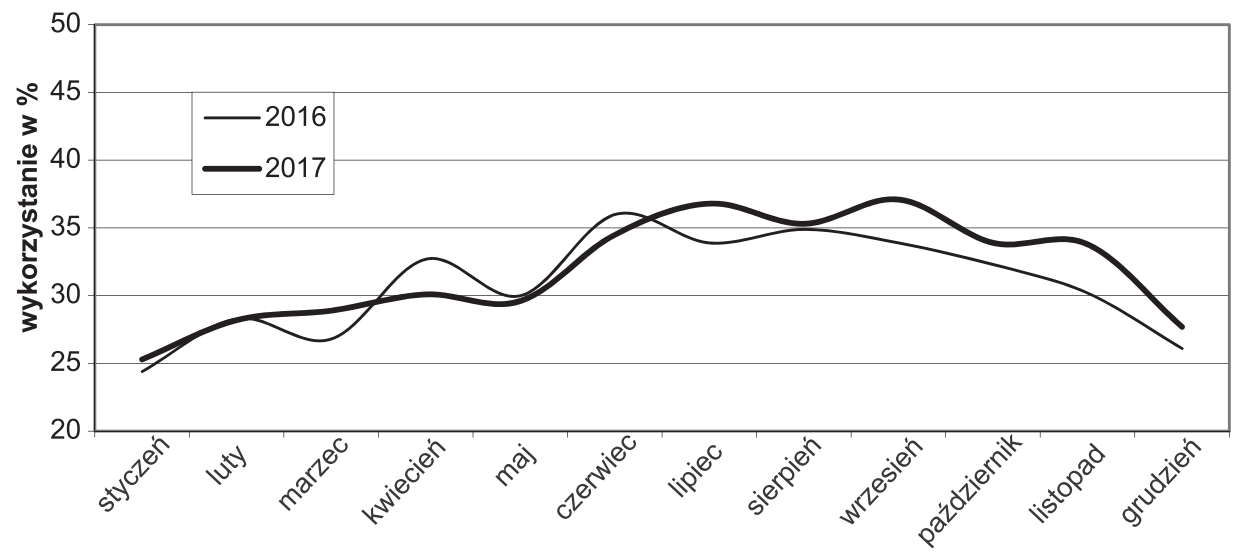

Rysunek 10. Zmiany w sezonowości wykorzystania obiektów bazy noclegowej województwa łódzkiego w latach 2016 i 2017

Źródło: opracowanie własne za: Bank Danych Lokalnych, https://www.bdl.stat.gov.pl (dostęp 15.02.2019) 
Potencjał i wykorzystanie turystycznej bazy noclegowej...

\begin{tabular}{|c|c|c|c|c|c|c|c|c|}
\hline 司 & & $\overrightarrow{0}$ & $\stackrel{2}{o}$ & $\begin{array}{l}0 \\
\infty \\
a^{0}\end{array}$ & वे & & 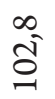 & $\hat{\infty}$ \\
\hline$\nabla$ & & $\stackrel{g}{=}$ & $\stackrel{\infty}{=-}$ & $\begin{array}{l}0 \\
0^{-} \\
0^{\prime}\end{array}$ & $\begin{array}{l}2 \\
\infty^{-} \\
0^{-1}\end{array}$ & & $\begin{array}{l} \pm \\
\stackrel{-}{二}\end{array}$ & 동 \\
\hline$x$ & & $\begin{array}{l}0 \\
0 \\
0\end{array}$ & $\ddot{2}$ & 정 & $\stackrel{1}{-}$ & & $\begin{array}{l}0 \\
\hat{0} \\
\stackrel{-}{1}\end{array}$ & \begin{tabular}{l}
0 \\
\multirow{0}{0}{}
\end{tabular} \\
\hline$\not{A}$ & & $\begin{array}{l}+ \\
\stackrel{\sigma}{0}\end{array}$ & $\cong$ & $\exists$ & ָิ & & $\stackrel{\vartheta}{\stackrel{\vartheta}{=}}$ & $\stackrel{n}{\beth}$ \\
\hline 寻 & & $\stackrel{\Rightarrow}{\circ}$ & $\begin{array}{l}+ \\
\text { ă }\end{array}$ & $\hat{\sigma}$ & $\begin{array}{l}+ \\
\stackrel{+}{\Xi}\end{array}$ & & $\tilde{n}^{2}$ & $\stackrel{n}{1}$ \\
\hline 寻 & & $\begin{array}{l}0 \\
\infty \\
0^{-}\end{array}$ & $\stackrel{\sim}{\tilde{n}^{\prime}}$ & $\begin{array}{l}+ \\
\sigma \\
=\end{array}$ & $\stackrel{ }{-}$ & & $\begin{array}{l}\stackrel{+}{\oplus} \\
\stackrel{=}{二}\end{array}$ & $\begin{array}{l} \pm \\
\pm \\
\pm\end{array}$ \\
\hline 5 & & $\begin{array}{l}\infty \\
\infty \\
\sigma\end{array}$ & స̆ & ন & $\stackrel{\overbrace{}}{\tilde{o}}$ & & $\overrightarrow{8}$ & ঠ \\
\hline$>$ & & $\hat{\sigma^{\circ}}$ & ă & নू & $\begin{array}{l}\text { aे } \\
\text { वे }\end{array}$ & & $\overrightarrow{\sigma^{-}}$ & ర్- \\
\hline$\geq$ & & ㅇ. & $\begin{array}{l}+ \\
\text { ล }\end{array}$ & $\underset{\sigma}{+}$ & $\hat{a}$ & & สิ & $\frac{0}{a}$ \\
\hline 目 & & $\stackrel{\infty}{\stackrel{\infty}{0}}$ & $\stackrel{a}{\sigma}$ & $\begin{array}{l}0 \\
\sigma^{-} \\
=\end{array}$ & $\tilde{\infty}_{\infty}^{n}$ & & $\stackrel{\Xi}{\approx}$ & $\stackrel{\beth}{\beth}$ \\
\hline 曰 & & å & $\stackrel{2}{ \pm}$ & $\stackrel{\vec{J}}{\stackrel{7}{0}}$ & $\tilde{n}_{\infty}^{1}$ & & $\begin{array}{l}0 \\
\hat{0}\end{array}$ & $\stackrel{n}{2}$ \\
\hline 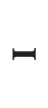 & & $\hat{\tilde{\sigma}}$ & $\stackrel{a}{\circ}$ & $\stackrel{+}{+}$ & $\stackrel{\vartheta}{\beth}$ & & $\hat{\tilde{J}}$ & $\overrightarrow{0}$ \\
\hline & 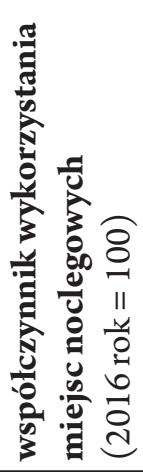 & 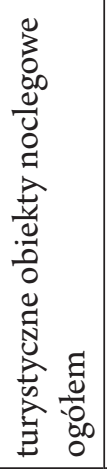 & 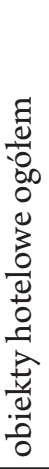 & 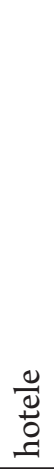 & 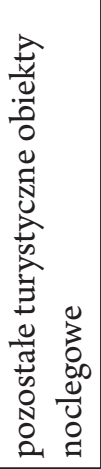 & 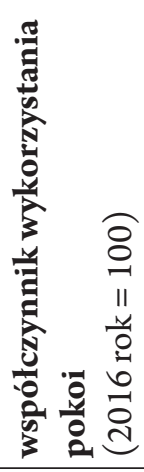 & 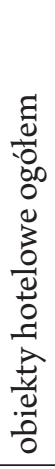 & 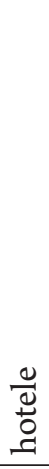 \\
\hline
\end{tabular}


zlokalizowana jest w Łodzi i pozostałych miastach województwa łódzkiego - stąd też wśród hoteli dominują miejskie, obsługujące głównie turystów biznesowych. W związku z tym, że spotkania biznesowe czy konferencyjne organizowane są najczęściej poza okresem wakacyjno-urlopowym, najwyższy stopień wykorzystania obiektów hotelarskich w czerwcu, wrześniu i październiku nie budzi zdziwienia. Należy ponadto zwrócić uwagę na fakt, że większość najważniejszych spotkań, sympozjów, konferencji organizowana jest głównie w owym właśnie okresie.

$\mathrm{W}$ stosunku do poprzedniego roku zmiany $\mathrm{w}$ poziomie wykorzystania obiektów noclegowych w poszczególnych miesiącach 2017 roku były wyraźne (rys. 10, tab. 18). Największym wzrostem wykorzystania charakteryzowały się takie miesiące jak marzec (wartość współczynnika sezonowości dla wszystkich obiektów noclegowych - 107,8, obiektów hotelowych - 115,9, samych hoteli - 116,6; wartość współczynnika wykorzystania pokoi dla obiektów hotelowych - 121,7 i samych hoteli - 121,1), lipiec (odpowiednio: 108,6, 113,2, 116,4, 113,4 i 114,4), wrzesień (odpowiednio: 109,4, 111,7, 111,1 113,9 i 112,4) i listopad (odpowiednio: 111,9, 111,8, 106,6 110,4 i 107,1). Największe spadki odnotowano w lutym i miesiącach wiosennych - kwietniu, maju, czerwcu.

Analizując wykorzystanie miejsc noclegowych w ujęciu przestrzennym warto w pierwszym rzędzie zwrócić uwagę na rozmieszczenie obiektów noclegowych. Obok Łodzi, która pod względem wielkości bazy noclegowej zdecydowanie dominuje w regionie, w województwie wyróżniają się powiaty: tomaszowski z największymi walorami regionu (Pilica, Spała, Zalew Sulejowski), piotrkowski (dolina Pilicy), bełchatowski (duże zalesienie, sztuczne akweny w pobliżu kopalni węgla brunatnego), wieluński (dolina Warty) i zgierski (strefa krawędziowa Wyżyny Łódzkiej).

Tabela 19. Wykorzystanie miejsc noclegowych w powiatach województwa łódzkiego w latach 2010-2017

\begin{tabular}{|l|c|c|c|c|c|c|c|c|}
\cline { 2 - 10 } \multicolumn{1}{c|}{} & \multicolumn{7}{c|}{ Stopień wykorzystania (w \%) } \\
\cline { 2 - 10 } \multicolumn{1}{c|}{} & $\mathbf{2 0 1 0}$ & $\mathbf{2 0 1 1}$ & $\mathbf{2 0 1 2}$ & $\mathbf{2 0 1 3}$ & $\mathbf{2 0 1 4}$ & $\mathbf{2 0 1 5}$ & $\mathbf{2 0 1 6}$ & $\mathbf{2 0 1 7}$ \\
\cline { 2 - 10 } & 1 & 2 & 3 & 4 & 5 & 6 & 7 & 8 \\
\hline $\begin{array}{l}\text { województwo } \\
\text { bódzkie }\end{array}$ & 31,1 & 30,3 & 29,2 & 26,8 & 27,9 & 30,6 & 31,0 & 32,0 \\
\hline poddębicki & 25,9 & 32,1 & 27,0 & 30,4 & 35,8 & 42,4 & 42,8 & 43,9 \\
\hline m. Łódź & 34,7 & 33,2 & 32,6 & 28,7 & 30,6 & 35,9 & 36,8 & 37,9 \\
\hline tomaszowski & 36,6 & 34,7 & 35,2 & 34,8 & 35,0 & 32,5 & 34,7 & 35,7 \\
\hline
\end{tabular}




\begin{tabular}{|c|c|c|c|c|c|c|c|c|}
\hline & 1 & 2 & 3 & 4 & 5 & 6 & 7 & 8 \\
\hline laski & 37,8 & 31,7 & 26,5 & 27,3 & 32,1 & 34,2 & 31,2 & 31,6 \\
\hline pabianicki & 23,9 & 24,8 & 25,3 & 24,0 & 24,4 & 32,4 & 29,9 & 30,9 \\
\hline sieradzki & 27,7 & 28,7 & 29,4 & 27,6 & 26,8 & 31,1 & 30,5 & 30,4 \\
\hline wieluński & 33,3 & 31,9 & 30,6 & 29,1 & 27,2 & 27,5 & 27,6 & 30,1 \\
\hline piotrkowski & 31,5 & 30,9 & 26,0 & 27,3 & 24,2 & 25,3 & 28,1 & 29,7 \\
\hline kutnowski & 35,2 & 42,4 & 31,4 & 28,8 & 33,2 & 33,3 & 35,6 & 29,6 \\
\hline bełchatowski & 35,3 & 28,3 & 27,7 & 22,9 & 26,0 & 30,0 & 30,5 & 27,4 \\
\hline skierniewicki & $\mathrm{t}$ & $\mathrm{t}$ & $\mathrm{t}$ & $\mathrm{t}$ & $\mathrm{t}$ & $\mathrm{t}$ & 17,4 & 27,1 \\
\hline zgierski & 26,7 & 24,6 & 24,1 & 20,3 & 21,2 & 24,0 & 25,1 & 26,7 \\
\hline pajęczański & $\mathrm{t}$ & 9,3 & 17,3 & 10,9 & 10,5 & 9,4 & 19,9 & 26,5 \\
\hline $\begin{array}{l}\text { m. Piotrków } \\
\text { Trybunalski }\end{array}$ & 23,0 & 28,2 & 26,4 & 21,5 & 19,1 & 21,5 & 23,8 & 26,3 \\
\hline łęczycki & $\mathrm{t}$ & $\mathrm{t}$ & 37,2 & 35,0 & 39,4 & 32,5 & 34,8 & 25,5 \\
\hline rawski & 31,9 & 33,0 & 32,6 & 29,7 & 30,8 & 30,3 & 27,8 & 24,2 \\
\hline wieruszowski & 30,8 & 23,2 & 22,1 & 26,9 & 23,5 & 21,6 & 22,4 & 24,1 \\
\hline łódzki wschodni & 25,3 & 22,5 & 25,2 & 24,0 & 21,5 & 25,1 & 20,3 & 21,0 \\
\hline radomszczański & 27,2 & 27,8 & 23,7 & 23,0 & 26,7 & 25,6 & 20,2 & 20,9 \\
\hline łowicki & 22,2 & 28,0 & 17,9 & 14,4 & 18,1 & 20,2 & 22,9 & 20,7 \\
\hline zduńskowolski & 13,2 & 14,1 & 17,0 & 18,4 & 14,8 & 10,8 & 12,0 & 17,6 \\
\hline opoczyński & 17,7 & 24,3 & 15,1 & 14,3 & 13,1 & 16,1 & 15,5 & 17,3 \\
\hline brzeziński & 23,5 & 29,1 & 25,1 & 24,7 & 24,7 & 18,0 & 14,3 & 13,0 \\
\hline m. Skierniewice & 21,2 & 22,0 & 23,1 & $\mathrm{t}$ & $\mathrm{t}$ & $\mathrm{t}$ & $\mathrm{t}$ & $\mathrm{t}$ \\
\hline
\end{tabular}

$\mathrm{t}$ - tajemnica statystyczna

Źródło: opracowanie własne za: Bank Danych Lokalnych, https://www.bdl.stat. gov.pl (dostęp 15.02.2019). 


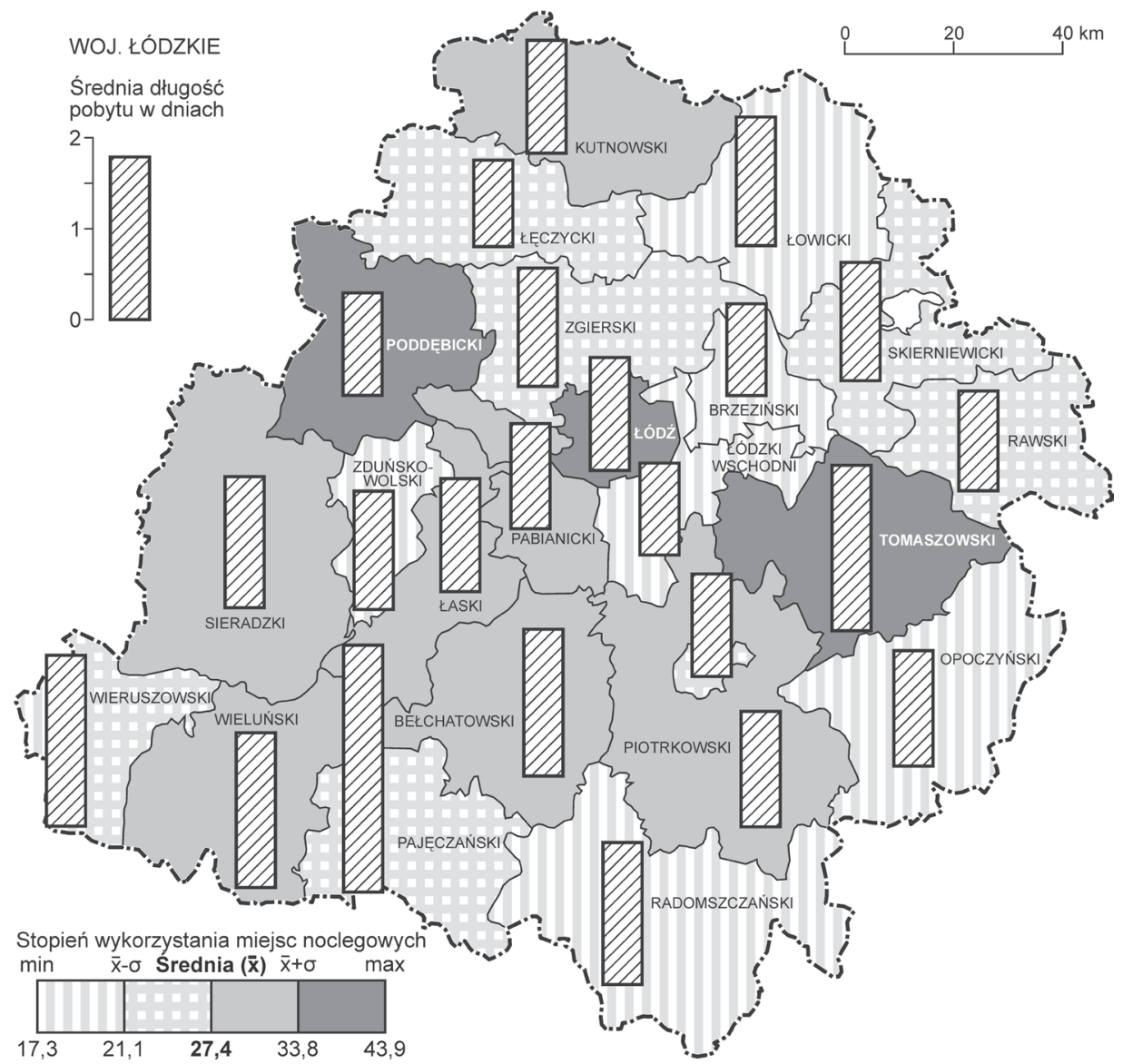

Rysunek 11. Stopień wykorzystania miejsc noclegowych i średnia długość pobytu w powiatach województwa łódzkiego w 2017 roku Źródło: opracowanie własne za: Bank Danych Lokalnych, https://www.bdl.stat.gov.pl (dostęp 15.02.2019)

Największym wykorzystaniem miejsc noclegowych w województwie łódzkim charakteryzuje się powiat poddębicki (jedyny, gdzie wykorzystanie przekroczyło w 2017 roku 40\% i wyniosło 43,9\%) (rys. 11, tab. 19). To największe obłożenie tłumaczy specyfika bazy noclegowej - w leżącym w powiecie Uniejowie znajduje się wielkie kąpielisko termalne, zamek z hotelem i jedyny w województwie zakład uzdrowiskowy, gdzie obłożenie wynosi średnio ponad $80 \%$.

W 2017 roku w przedziale 30,1-40\% wykorzystania miejsc noclegowych znalazła się Łódź $(37,9 \%)$ i pięć powiatów: tomaszowski $(35,7 \%)$, laski (31,6\%), pabianicki (30,9\%), sieradzki (30,4\%) i wieluński (30,1\%). Najniższy 
stopień obłożenia, mniej niż $20 \%$, odnotowały w tymże roku trzy powiaty: zduńskowolski (17,6\%), opoczyński (17,3\%) i brzeziński (13\%).

Stopień wykorzystania bazy noclegowej w poszczególnych powiatach województwa łódzkiego w latach 2011-2017 podlegał znacznym fluktuacjom. Największe wahania współczynnika zmian wykorzystania bazy noclegowej odnotowano w powiecie pajęczańskim ( 63 w 2013 roku i 211,7 w 2016 roku) (tab. 20). Nieco mniejszym zmianom tego współczynnika podlegały powiaty: łowicki, skierniewicki, zduńskowolski i wieruszowski. Tak duże wahania współczynnika wykorzystania miejsc noclegowych w krótkim siedmioletnim okresie są dla właścicieli obiektów zjawiskiem niekorzystnym - nie mogą oni bowiem w sposób racjonalny gospodarować nimi, zaciągać kredytów, tworzyć planów na przyszłość itp.

Najmniejszym wahaniom wspomnianego współczynnika podlegały powiaty tomaszowski $(92,9-106,8)$ i wieluński $(93,5-109,1)$.

Tabela 20. Dynamika zmian wykorzystania obiektów bazy noclegowej województwa łódzkiego w latach 2011-2017 według powiatów

\begin{tabular}{|l|c|c|c|c|c|c|c|}
\cline { 2 - 9 } & \multicolumn{7}{c|}{ Współczynnik zmian: poprzedni rok= 100 } \\
\cline { 2 - 9 } & $\mathbf{2 0 1 1}$ & $\mathbf{2 0 1 2}$ & $\mathbf{2 0 1 3}$ & $\mathbf{2 0 1 4}$ & $\mathbf{2 0 1 5}$ & $\mathbf{2 0 1 6}$ & $\mathbf{2 0 1 7}$ \\
\cline { 2 - 9 } & 1 & 2 & 3 & 4 & 5 & 6 & 7 \\
\hline województwo lódzkie & 97,4 & 96,4 & 91,8 & 104,1 & 109,7 & 101,3 & 103,2 \\
\hline bełchatowski & 80,2 & 97,9 & 82,7 & 113,5 & 115,4 & 101,7 & 89,8 \\
\hline brzeziński & 123,8 & 86,3 & 98,4 & 100,0 & 72,9 & 79,4 & 90,9 \\
\hline kutnowski & 120,5 & 74,1 & 91,7 & 115,3 & 100,3 & 106,9 & 83,1 \\
\hline laski & 83,9 & 83,6 & 103,0 & 117,6 & 106,5 & 91,2 & 101,3 \\
\hline lęczycki & $\mathrm{t}$ & $\mathrm{t}$ & 94,1 & 112,6 & 82,5 & 107,1 & 73,3 \\
\hline lowicki & 126,1 & 63,9 & 80,4 & 125,7 & 111,6 & 113,4 & 90,4 \\
\hline lódzki wschodni & 88,9 & 112,0 & 95,2 & 89,6 & 116,7 & 80,9 & 103,4 \\
\hline m. Łódź & 95,7 & 98,2 & 88,0 & 106,6 & 117,3 & 102,5 & 103,0 \\
\hline m. Piotrków & 122,6 & 93,6 & 81,4 & 88,8 & 112,6 & 110,7 & 110,5 \\
\hline Trybunalski & 103,8 & 105,0 & $\mathrm{t}$ & $\mathrm{t}$ & $\mathrm{t}$ & $\mathrm{t}$ & $\mathrm{t}$ \\
\hline m. Skierniewice & 137,3 & 62,1 & 94,7 & 91,6 & 122,9 & 96,3 & 111,6 \\
\hline opoczyński & & & & & & \\
\hline
\end{tabular}


Tabela 20 (cd.)

\begin{tabular}{|l|c|c|c|c|c|c|c|}
\cline { 2 - 8 } \multicolumn{1}{c|}{} & 1 & \multicolumn{1}{c|}{2} & \multicolumn{1}{c|}{3} & \multicolumn{1}{c|}{4} & \multicolumn{1}{c|}{5} & \multicolumn{1}{c|}{6} & 7 \\
\hline pabianicki & 103,8 & 102,0 & 94,9 & 101,7 & 132,8 & 92,3 & 103,3 \\
\hline pajęczański & $\mathrm{t}$ & 186,0 & 63,0 & 96,3 & 89,5 & 211,7 & 133,2 \\
\hline piotrkowski & 98,1 & 84,1 & 105,0 & 88,6 & 104,5 & 111,1 & 105,7 \\
\hline poddębicki & 123,9 & 84,1 & 112,6 & 117,8 & 118,4 & 100,9 & 102,6 \\
\hline radomszczański & 102,2 & 85,3 & 97,0 & 116,1 & 95,9 & 78,9 & 103,5 \\
\hline rawski & 103,4 & 98,8 & 91,1 & 103,7 & 98,4 & 91,7 & 87,1 \\
\hline sieradzki & 103,6 & 102,4 & 93,9 & 97,1 & 116,0 & 98,1 & 99,7 \\
\hline skierniewicki & $\mathrm{t}$ & $\mathrm{t}$ & $\mathrm{t}$ & $\mathrm{t}$ & $\mathrm{t}$ & 100,0 & 155,7 \\
\hline tomaszowski & 94,8 & 101,4 & 98,9 & 100,6 & 92,9 & 106,8 & 102,9 \\
\hline wieluński & 95,8 & 95,9 & 95,1 & 93,5 & 101,1 & 100,4 & 109,1 \\
\hline wieruszowski & 75,3 & 95,3 & 121,7 & 87,4 & 91,9 & 103,7 & 107,6 \\
\hline zduńskowolski & 106,8 & 120,6 & 108,2 & 80,4 & 73,0 & 111,1 & 146,7 \\
\hline zgierski & 92,1 & 98,0 & 84,2 & 104,4 & 113,2 & 104,6 & 106,4 \\
\hline
\end{tabular}

$\mathrm{t}$ - tajemnica statystyczna

Źródło: opracowanie własne za: Bank Danych Lokalnych, https://www.bdl.stat. gov.pl (dostęp 15.02.2019).

\subsubsection{Podsumowanie}

Stopień wykorzystania (obłożenia) bazy noclegowej w województwie łódzkim jest wysoce niezadowalający, co potwierdza Włodarczyk (Włodarczyk 2014: 275). Wykorzystanie to liczone dla całego województwa w 2017 roku wyniosło $32 \%$ i było o ponad siedem punktów procentowych niższe niż średnie dla Polski (39,3\%). Sytuacją niekorzystną dla województwa jest fakt, że tylko jeden powiat (poddębicki) ma obłożenie większe, niż ta średnia.

W rankingu dotyczącym wykorzystania miejsc noclegowych w 380 powiatach, sporządzonym w 2017 roku (tab. 21), powiaty województwa łódzkiego wypadają wręcz bardzo słabo. W pierwszej pięćdziesiątce jest wyłącznie jeden powiat: poddębicki (35. miejsce; a w pierwszej setce jeszcze tylko dwa inne: Łódź (65. miejsce z wykorzystaniem 37,9\%) i powiat tomaszowski (82. miejsce i $35,7 \%$ ). W drugiej setce (obłożenie 33,5-27,5\%) rankingu znalazło się siedem powiatów województwa łódzkiego, w trzeciej (obłożenie 27,4-21\%) - osiem i w ostatniej, czwartej - pozostałych sześć. 
Potencjał i wykorzystanie turystycznej bazy noclegowej...

Tabela 21. Ranking powiatów pod względem wykorzystania miejsc noclegowych w Polsce w 2017 roku

\begin{tabular}{|c|c|c|}
\hline $\begin{array}{c}\text { Miejsce } \\
\text { w rankingu }\end{array}$ & Powiat & $\begin{array}{c}\text { Stopień } \\
\text { wykorzystania } \\
(\mathbf{w} \%)\end{array}$ \\
\hline 1 & 2 & 3 \\
\hline 1 & inowrocławski & 70,8 \\
\hline 2 & aleksandrowski & 69,3 \\
\hline 3 & buski & 68,1 \\
\hline 4 & lubaczowski & 67,5 \\
\hline 5 & kołobrzeski & 64,7 \\
\hline 6 & krośnieński & 60,9 \\
\hline 7 & m. Świnoujście & 56,9 \\
\hline 8 & m.st. Warszawa & 56,5 \\
\hline 9 & włocławski & 56,3 \\
\hline 10 & m. Ruda Śląska & 55,2 \\
\hline 35 & poddębicki & 43,9 \\
\hline 65 & m. Łódź & 37,9 \\
\hline 82 & tomaszowski & 35,7 \\
\hline 129 & łaski & 31,6 \\
\hline 141 & pabianicki & 30,9 \\
\hline 148 & sieradzki & 30,4 \\
\hline 153 & wieluński & 30,1 \\
\hline 162 & piotrkowski & 29,7 \\
\hline 164 & kutnowski & 29,6 \\
\hline 197 & bełchatowski & 27,4 \\
\hline 205 & skierniewicki & 27,1 \\
\hline 210 & zgierski & 26,7 \\
\hline 216 & pajęczański & 26,5 \\
\hline 220 & m. Piotrków Trybunalski & 26,3 \\
\hline
\end{tabular}


Tabela 21 (cd.)

\begin{tabular}{|c|l|c|}
\hline 1 & \multicolumn{1}{|c|}{2} & 3 \\
\hline 233 & lęczycki & 25,5 \\
\hline 252 & rawski & 24,2 \\
\hline 255 & wieruszowski & 24,1 \\
\hline 299 & lódzki wschodni & 21,0 \\
\hline 301 & radomszczański & 20,9 \\
\hline 305 & lowicki & 20,7 \\
\hline 334 & zduńskowolski & 17,6 \\
\hline 337 & opoczyński & 17,3 \\
\hline 360 & brzeziński & 13,0 \\
\hline 372 & m. Skierniewice & $\mathrm{t}$ \\
\hline
\end{tabular}

$\mathrm{t}$ - tajemnica statystyczna

Źródło: opracowanie własne za: Bank Danych Lokalnych, https://www.bdl.stat. gov.pl (dostęp 15.02.2019).

Jak już wcześniej wspominano, województwo łódzkie na tle Polski nie wyróżnia się szczególnie wysoką atrakcyjnością turystyczną - wskaźnik atrakcyjności turystycznej liczony zarówno dla województwa, jak i powiatów osiąga jedne $\mathrm{z}$ najniższych wartości (tab. 12). W województwie relatywnie najwyższym WAT-em charakteryzuje się Łódź, Piotrków Trybunalski i kilka powiatów sąsiadujących z Łodzią - łódzki wschodni, pabianicki i zgierski. Z porównania tabeli 12 . z tabelą 21 . jednoznacznie wynika, że atrakcyjność turystyczna powiatów nie ma bezpośredniego przełożenia na stopień wykorzystania miejsc noclegowych w województwie - z wyjątkiem Łodzi, najatrakcyjniejsze z nich nie mają największego odsetka obłożenia.

\section{Bibliografia}

Bednarska U., Musiał W., 1973, Zagospodarowanie turystyczne regionu łódzkiego, „Region Łódzki. Studia i Materiały”, t. 3, s. 203-224.

Jokiel B., Kostrubiec B., 1981, Statystyka z elementami matematyki dla geografów, Państwowe Wydawnictwo Naukowe, Warszawa. 
Kowalczyk A., 2001a, Geografia hotelarstwa, Wydawnictwo Uniwersytetu Łódzkiego, Łódź.

Milewska M., Skrzypczyński M., Włodarczyk B., 2004, Mierniki jako ważny element nauczania hotelarstwa, „Turystyka i Hotelarstwo” nr 5, s. 107-133.

Turystyka w 1990 roku, 1991, Główny Urząd Statystyczny, Warszawa.

Turystyka w 1995 roku, 1996, Główny Urząd Statystyczny, Warszawa.

Turystyka w 1996 roku, 1997, Główny Urząd Statystyczny, Warszawa.

Turystyka w 1997 roku, 1998, Główny Urząd Statystyczny, Warszawa.

Turystyka w 1998 roku, 1999, Główny Urząd Statystyczny, Warszawa.

Turystyka w 1999 roku, 2000, Główny Urząd Statystyczny, Warszawa.

Turystyka w 2000 roku, 2001, Główny Urząd Statystyczny, Warszawa.

Turystyka w 2001 roku, 2002, Główny Urząd Statystyczny, Warszawa. Turystyka w 2002 roku, 2003, Główny Urząd Statystyczny, Warszawa. Turystyka w 2003 roku, 2004, Główny Urząd Statystyczny, Warszawa. Turystyka w 2004 roku, 2005, Główny Urząd Statystyczny, Warszawa. Turystyka w 2005 roku, 2006, Główny Urząd Statystyczny, Warszawa. Turystyka w 2006 roku, 2007, Główny Urząd Statystyczny, Warszawa. Turystyka w 2007 roku, 2008, Główny Urząd Statystyczny, Warszawa. Turystyka w 2008 roku, 2009, Główny Urząd Statystyczny, Warszawa. Turystyka w 2009 roku, 2010, Główny Urząd Statystyczny, Warszawa. Turystyka w 2010 roku, 2011, Główny Urząd Statystyczny, Warszawa. Turystyka w 2011 roku, 2012, Główny Urząd Statystyczny, Warszawa. Turystyka w 2012 roku, 2013, Główny Urząd Statystyczny, Warszawa. Turystyka w 2013 roku, 2014, Główny Urząd Statystyczny, Warszawa. Turystyka w 2014 roku, 2015, Główny Urząd Statystyczny, Warszawa. Turystyka w 2015 roku, 2016, Główny Urząd Statystyczny, Warszawa. Turystyka w 2016 roku, 2017, Główny Urząd Statystyczny, Warszawa. Turystyka w 2017 roku, 2018, Główny Urząd Statystyczny, Warszawa. Włodarczyk B., 2014, Baza noclegowa Łodzi i regionu łódzkiego na początku drugiej dekady XXI wieku, „Warsztaty z Geografii Turyzmu”, R. 5, s. 255-277.

Włodarczyk B. (red.), 2017, Ruch turystyczny w Łodzi i województwie tódzkim w 2016 roku, Instytutu Geografii Miast i Turyzmu Uniwersytetu Łódzkiego, Łódź.

\section{Netografia}

Bank Danych Lokalnych, https://www.bdl.stat.gov.pl (dostęp: 5.10.2018). 